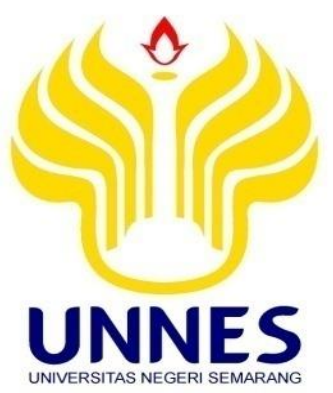

\title{
HUBUNGAN ANTARA KESENANGAN MENDENGARKAN MUSIK DANGDUT DENGAN TINGKAT PRODUKTIVITAS KARYAWAN HOME INDUSTRY TRIO DI DESA TEGALWANGI KABUPATEN TEGAL
}

\author{
Skripsi \\ Disajikan sebagai salah satu syarat \\ untuk memperoleh gelar Sarjana Pendidikan \\ Program Studi Pendidikan Seni Musik
}

Oleh :

Agung Mukti Prasetyo

2501412031

FAKULTAS BAHASA DAN SENI

UNIVERSITAS NEGERI SEMARANG

2016 


\section{PENGESAHAN KELULUSAN}

Skripsi ini telah di pertahankan di hadapan sidang Panitia Ujian Skripsi Jurusan Pendidikan Sendratasik, Fakultas Bahasa dan Seni, Universitas Negeri Semarang.

Pada Hari Kamis

Tanggal 2 Juni 2016

Panitia Ujian Skripsi

Prof. Dr. Muhammad Jazuli, M.Hum. (196107041988031003) Ketua

Dra. Malarsih, M.Sn. (196106171988032001) Sekertaris

Drs. Suharto, S.Pd, M.Hum. (196510181990031002) Penguji 1

Drs. Eko Raharjo, M.Hum. (196510181992031001) Penguji 2

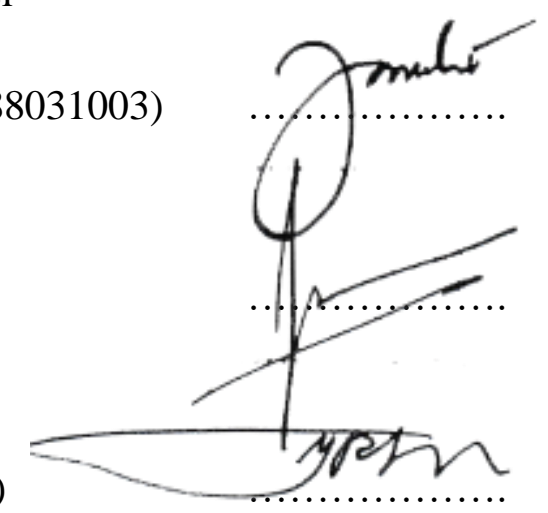

Prof. Dr. F. Totok Sumaryanto, M.Pd. (196410271991021001) Penguji 3

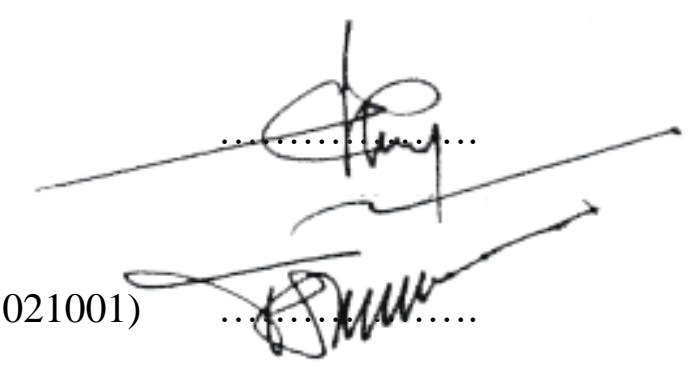

Prof. Dr. Agus Nuryatin, M.Hum. (196008031989011001)

Dekan Fakultas Bahasa dan Seni 


\section{PERNYATAAN}

Saya menyatakan bahwa yang tertulis di dalam skripsi ini benar-benar hasil karya saya sendiri, bukan jiplakan dari karya orang lain, baik sebagian atau seluruhnya. Pendapat atau temuan orang lain yang terdapat dalam skripsi ini dikutip atau dirujuk berdasarkan kode etik ilmiah.

Semarang, 2 Juni 2016

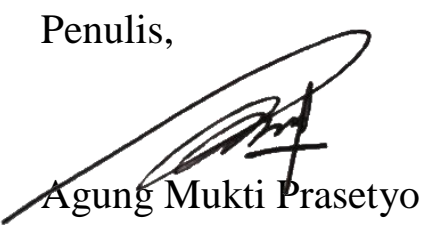

NIM. 2501412031 


\begin{abstract}
ABSTRAK
Prasetyo, Agung Mukti. 2016. Hubungan antara kesenangan mendengarkan musik dangdut dengan tingkat produktivitas karyawan Home Industry Trio di Desa Tegalwangi Kabupaten Tegal. Skripsi. Jurusan Pendidikan Seni Drama Tari dan Musik, Fakultas Bahasa dan Seni Universitas Negeri Semarang. Pembimbing I: Prof. Dr. F. Totok Sumaryanto, M.Pd. Pemimbing II: Drs. Eko Raharjo, M. Hum
\end{abstract}

\title{
Kata Kunci: Kesenangan Mendengarkan Musik Dangdut, Tingkat Produktivitas
}

Produktivitas merupakan aspek yang dimiliki oleh tiap insan manusia. Tingkatan antara manusia satu dengan lainya pun berbeda. Pada penelitian ini yang diteliti adalah tentang hubungan kesenangan mendengarkan musik dangdut dengan tingkat produktivitas karyawan Home Industry Trio Desa Tegalwangi Kabupaten Tegal.

Masalah yang dikaji dalam penelitian ini adalah (1) adakah korelasi antara kesenangan mendengarkan musik dangdut dengan tingkat produktivitas karyawan Home Industry Trio Desa Tegalwangi Kabupaten Tegal, (2) seberapa besar kontribusi kesenangan mendengarkan musik dangdut dengan tingkat produktivitas karyawan Home Industry Trio Desa Tegalwangi Kabupaten Tegal, (3) adakah pengaruh mendengarkan musik dangdut dengan tingkat produktivitas karyawan Home Industry Trio Desa Tegalwangi Kabupaten Tegal.

Penelitian yang digunakan adalah penelitian korelasi dengan pendekatan kuantitatif, Subyek yang digunakan adalah 30 karyawan yang dipilih dengan teknik random sampling. Teknik analisis data yang digunakan yaitu analisis deskriptif, uji prasyarat analisis meliputi uji normalitas dan linieritas, uji hipotesis 1 untuk mengetahui korelasi dan determinasi, uji hipotesis 2 untuk mengetahui persamaan regresi. Alat yang digunakan untuk menganalisa yaitu SPSS 16.0.

Hasil penelitian menunjukan bahwa tingkat kesenangan mendengarkan musik dangdut karywan mempengaruhi tingkat produktivitas karywan Home Industry Trio. Dari hasil penghitungan menggunakan SPSS diperoleh nilai rxy $=0,662, \mathrm{r}$ tabel $\mathrm{N}=30$ diketahui 0,361 . Hasilnya $r$ hitung $>r$ tabel, jadi dapat disimpulkan terdapat hubungan yang signifikan antara kesenangan mendengarkan musik dangdut dengan tingkat produktivitas karyawan Home Industry Trio. Kesenangan mendengarkan musik dangdut berpengaruh terhadap tingkat produtivitas karyawan Home Industry Trio sebesar 41,8\%, dengan persamaan regresi $Y=53,225+0,256 \mathrm{X}$.

Mengacu dari penelitian, maka penulis memberikan saran bagi pihak pimpinan Home Industry Trio hendaknya lebih meningkatkan fasilitas-fasilitas yang menunjang produktivitas karyawan bagi dari segi tempat yang nyaman maupun hakhak yang harus didapat oleh karyawan yang lain agar terjadi hubungan saling menguntungkan antara pihak yang satu dengan yang lainnya. 


\section{PRAKATA}

Alhamdulillah segala puja dan puji syukur penulis limpahkan kepada Allah

SWT. Karena berkat rahmat dan karunia-Nya penulis dapat melaksanakan dan menyelesaikan skripsi dengan judul "Hubungan antara Kesenangan Mendengarkan Musik Dangdut dengan Tingkat Produktivitas Karyawan Home Industry Trio di Desa Tegalwangi Kabupaten Tegal’”.

Penulis menyadari dengan sepenuh hati bahwa tersusunnya skripsi ini bukan hanya atas kemampuan dan usaha penulis semata, namun juga berkat bantuan dari berbagai pihak. Oleh karena itu, pada kesempatan kali ini penulis mengucapkan terimakasih yang sedalam-dalamnya kepada yang terhormat:

1. Prof. Dr. Fathur Rokhman, M.Hum. Rektor Universitas Negeri Semarang, yang telah memberikan kesempatan kepada penulis untuk menimba ilmu di kampus tercinta Universitas Negeri Semarang.

2. Prof. Dr. Agus Nuryatin, M.Hum. Dekan Fakultas Bahasa dan seni Universitas Negeri Semarang yang telah memberikan izin penelitian.

3. Dr. Udi Utomo, M.Si. Ketua Jurusan Pendidikan Seni Drama Tari dan Musik yang telah memberikan izin pada penyusun skripsi ini.

4. Prof. Dr. F. Totok Sumaryanto, M.Pd. (Dosen Pembimbing I) yang telah memberikan bimbingan, pengarahan, masukan, dan motivasi kepada penulis sehingga dapat menyelesaikan skripsi ini. 
5. Drs. Eko Raharjo M.Hum. (Dosen Pembimbing II) yang telah memberikan bimbingan, pengarahan, masukan, dan motivasi kepada penulis sehingga dapat menyeleaikan skripsi ini.

6. Bapak dan Ibu Dosen Jurusan Pendidikan Seni Musik yang telah memberikan bekal ilmu dan pengetahuan sehingga penulis mampu menyelesaikan penyusunan skripsi ini.

7. Bapak H. Rasbin, selaku pimpinan Home Industry Trio yang telah memberikan izin penelitian dan segala fasilitas selama penulis melakukan penelitian.

8. Seluruh karyawan Home Industry Trio yang telah bersedia dengan sepenuh hati menjadi sampel dalam penelitian ini.

9. Seluruh pihak yang tidak bisa penulis sebutkan satu persatu yang telah memberikan bantuan dan dorongan baik material maupun spiritual sehingga skripsi ini dapat terselesaikan.

Semoga Allah SWT memberikan pahala yang setimpal atas segala kebaikan yang telah mereka berikan selama penyusunan skripsi ini.

Penulis berharap semoga skripsi ini dapat bermanfaat bagi para pembaca semua.

Semarang, Mei 2016 


\title{
MOTTO DAN PERSEMBAHAN
}

\author{
Motto: \\ Pesan dari Alm. Bapak: Mudahkanlah segala urusan orang lain dan "Never put \\ off till tomorrow what you can do today" (Thomas Jefferson).
}

Persembahan:

1. Bapak Kasturi (Alm) dan Ibu Mutoyah tercinta atas doa, cinta dan kasih sayang yang tiada hentinya.

2. Kakak dan adiku, Mba Apink, Mas Isya, Mas Andi, Dek Intan dan seluruh keluarga besar yang selalu mendukung dan memotivasi.

3. Teman-temanku yang selalu mendoakan dan memberi semangat 


\section{DAFTAR ISI}

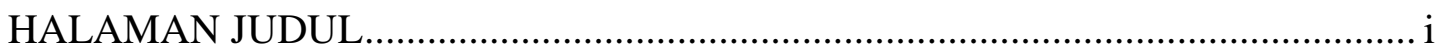

LEMBAR PENGESAHAN ........................................................................ ii

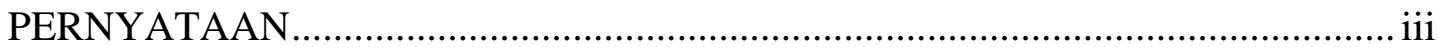

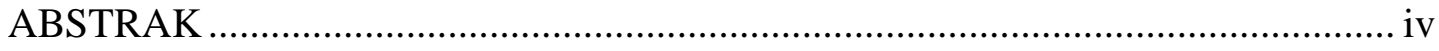

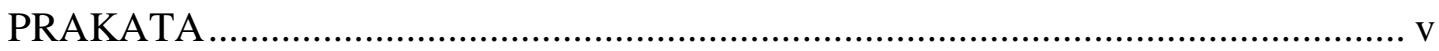

MOTO DAN PERSEMBAHAN ................................................................ vii

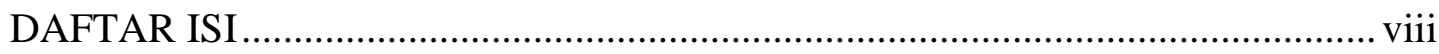

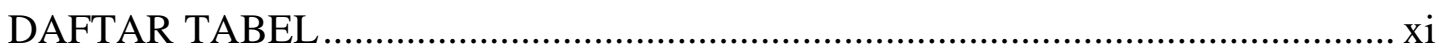

DAFTAR DIAGRAM ................................................................................

DAFTAR LAMPIRAN .........................................................................

BAB 1 PENDAHULUAN ............................................................................ 1

1.1 Latar Belakang ......................................................................... 1

1.2 Identifikasi Masalah ......................................................................... 4

1.3 Pembatasan Masalah .......................................................................... 5

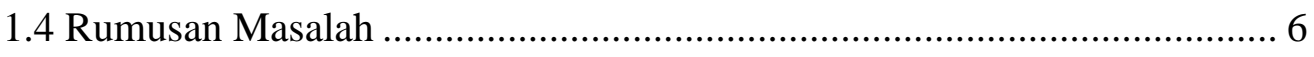

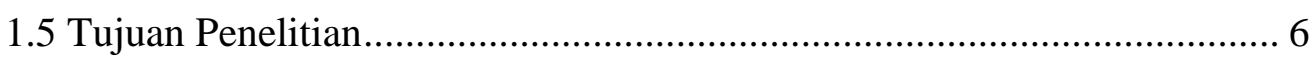

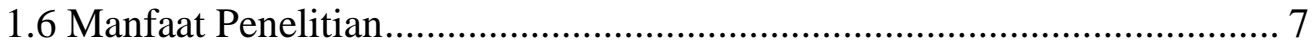

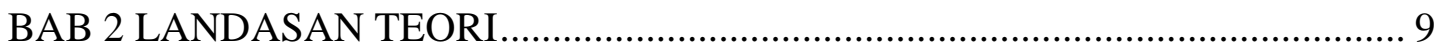

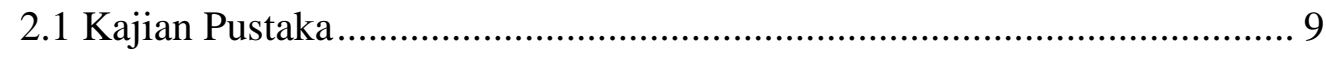

2.2 Pengertian Kesenangan Mendengarkan Musik Dangdut ....................... 10

2.3 Pengertian Produktivitas Karyawan ................................................. 19 


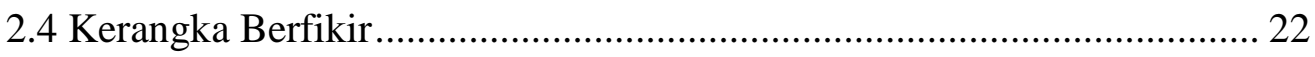

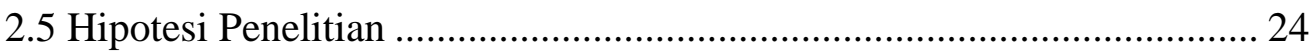

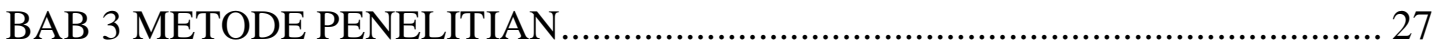

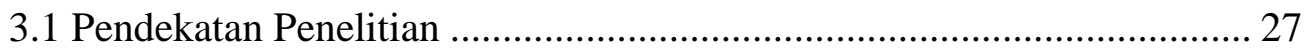

3.2 Tempat dan Waktu Penelitian ............................................................ 27

3.3 Populasi dan Sampel .................................................................... 28

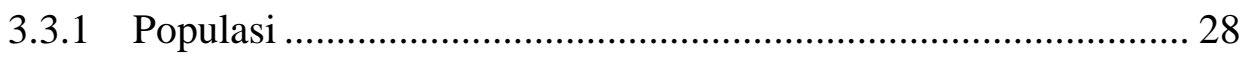

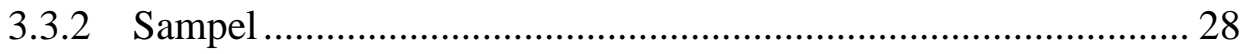

3.4 Variabel Penelitian .............................................................................. 29

3.4.1 Variabel Bebas (X) ................................................................ 29

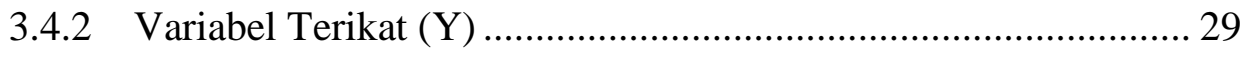

3.5 Definisi Operasional......................................................................... 30

3.5.1 Kesenangan Mendengar Musik Dangdut …………………….... 30

3.5.2 Tingkat Produktivitas ................................................................ 31

3.6 Teknik Pengumpulan Data ...................................................................... 31

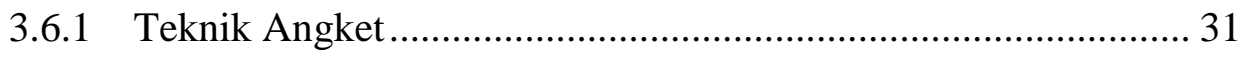

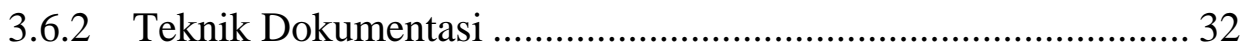

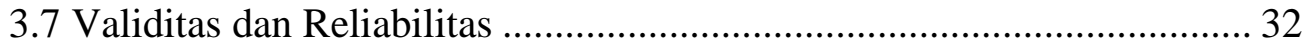

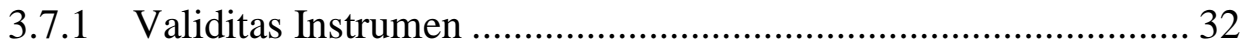

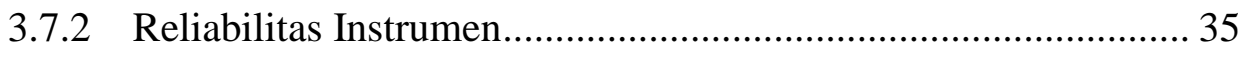

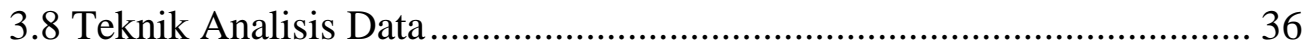

3.8.1 Analisis Deskriptif Prosentase...................................................... 36

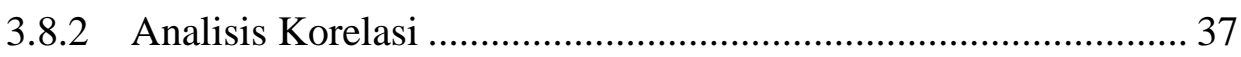

3.8.3 Uji Prasyarat Analisi ................................................................. 38

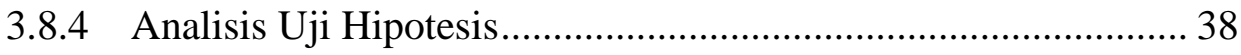

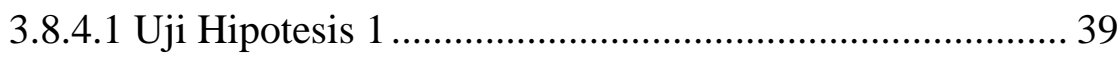

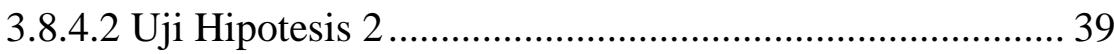


BAB 4 HASIL PENELITIAN DAN PEMBAHASAN ........................................ 40

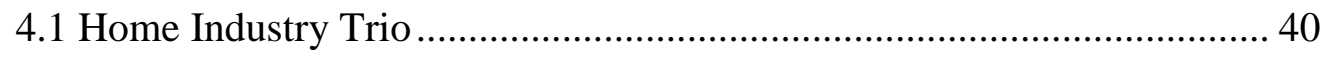

4.2 Hasil Penelitian ........................................................................... 41

4.2.1 Deskripsi Data ........................................................... 41

4.2.1.1 Variabel Tingkat Produktivitas (Y) ......................... 41

4.2.1.2 Variabel Tingkat Kesenangan Mendengar Musik

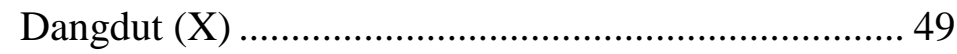

4.2.2 Uji Prasyarat Analisis ..................................................... 58

4.2.2.1 Normalitas Data .................................................. 58

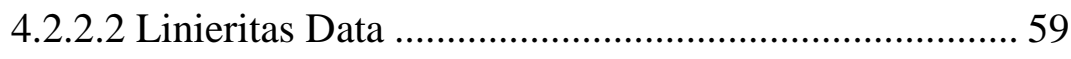

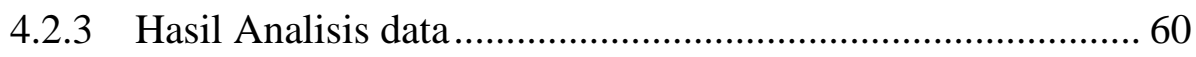

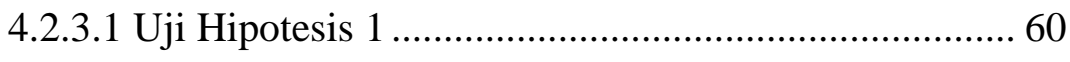

4.2.3.1.1 Analisis Korlasi ......................................... 60

4.2.3.1.2 Determinasi ............................................ 62

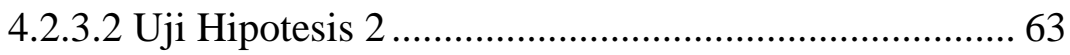

4.2.3.2.1 Persamaan Regresi .................................... 63

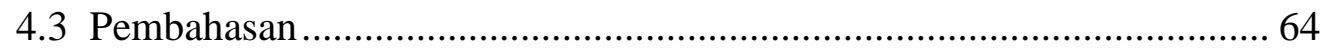

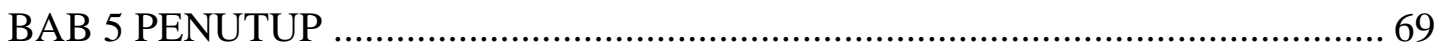

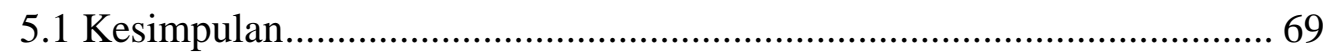

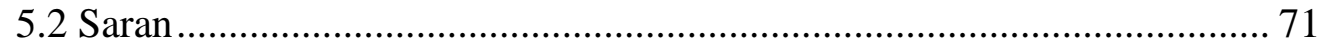

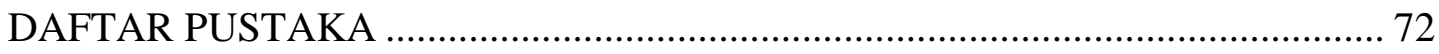

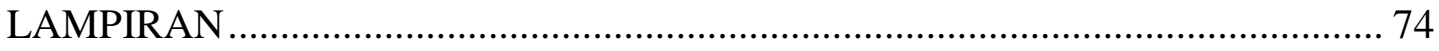




\section{DAFTAR TABEL}

3.1 Kisi-kisi Angket Kesenangan Mendengar Musik Dangdut ................................. 32

3.2 Kisi-kisi Borang Penilaian Tingkat Produktivitas............................................ 33

3.3 Hasil Uji Validitas Instrumen Kesenangan Mendengarkan Musik Dangdut ....... 34

4.1 Nilai Rata-rata Tingkat Produktivitas ............................................................. 42

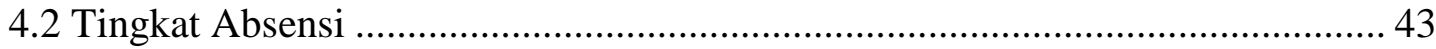

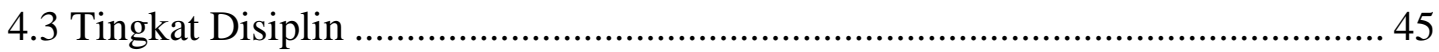

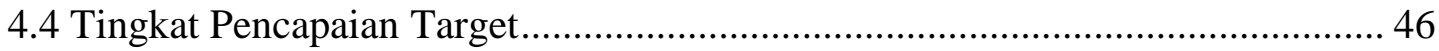

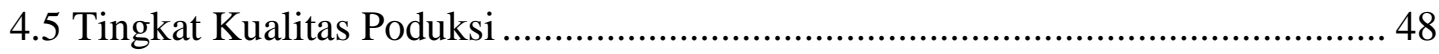

4.6 Nilai Rata-rata Tingkat Kesenangan Mendengarkan Musik Dangdut ................. 50

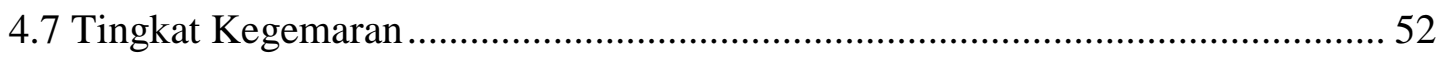

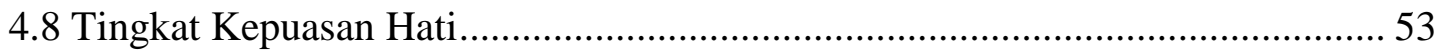

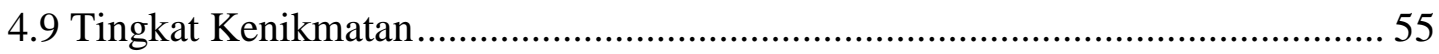

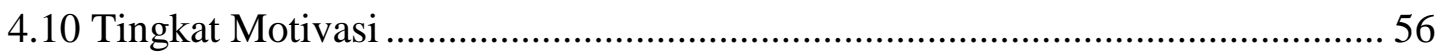

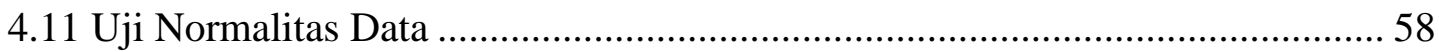

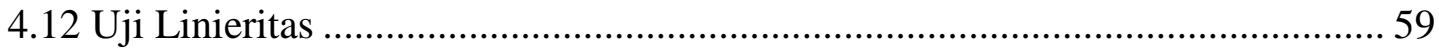

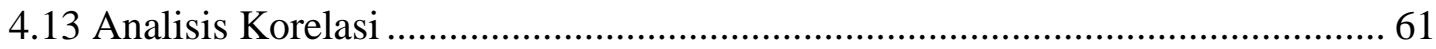

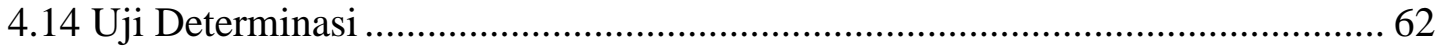

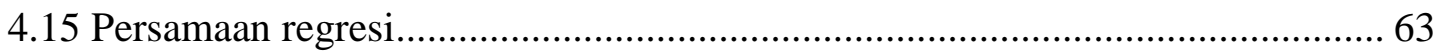




\section{DAFTAR DIAGRAM}

4.1 Distribusi Frekuensi Tingkat Produktivitas Karyawan ................................... 43

4.2 Distribusi Frekuensi Tingkat Absensi ......................................................... 44

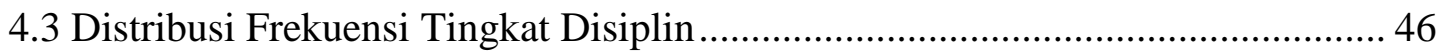

4.4 Distribusi Frekuensi Tingkat Pencapaian Target ........................................... 47

4.5 Distribusi Frekuensi Tingkat Kualitas Produksi .............................................. 49

4.6 Distribusi Frekuensi Tingkat Kesenangan Mendengarkan Musik Dangdut ........ 51

4.7 Distribusi Frekuensi Tingkat Kegemaran ................................................... 53

4.8 Distribusi Frekuensi Tingkat Kepuasan hati ............................................... 54

4.9 Distribusi Frekuensi Tingkat Kenikmatan .................................................. 56

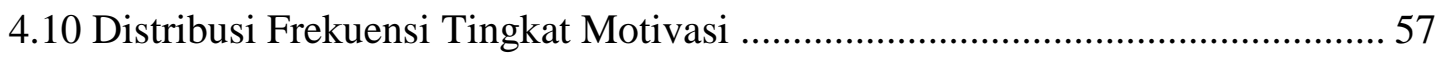




\section{DAFTAR LAMPIRAN}

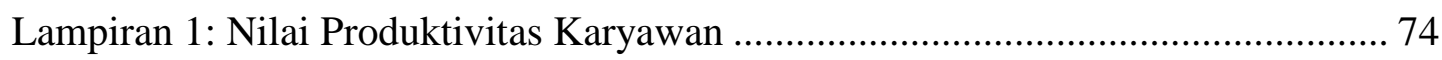

Lampiran 2: Nilai Kesenangan Mendengarkan Musik Dangdut............................ 76

Lampiran 3: Uji Validitas dan Reliabilitas Instrumen ......................................... 77

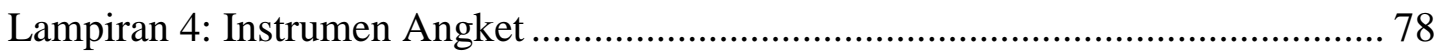

Lampiran 5: Instrumen Borang Penilaian Tingkat Produktivitas ............................ 83

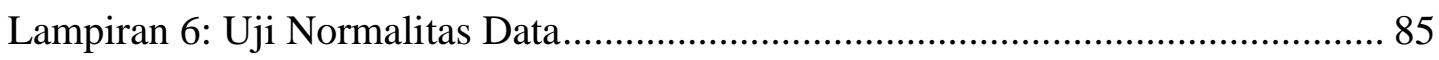

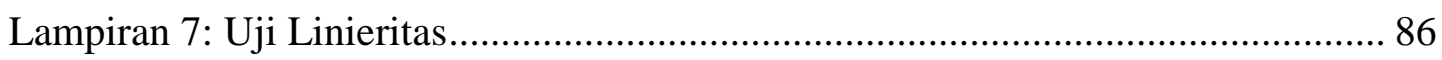

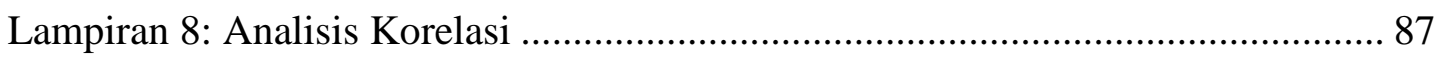

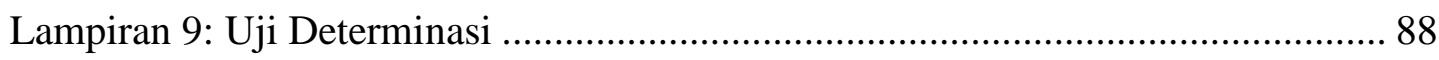

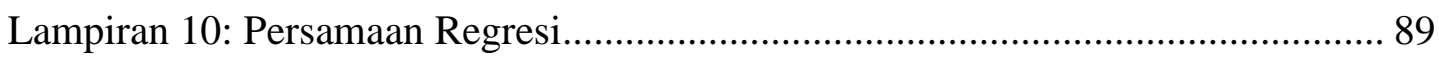

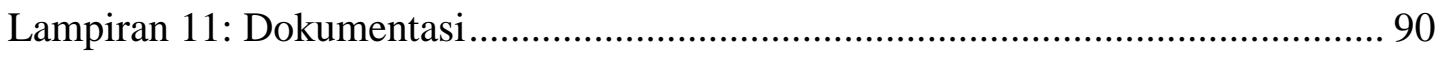

Lampiran 12: Permohonan Izin Penelitian...................................................... 91

Lampiran 13: Penetapan Dosen Pembimbing .................................................. 92 



\section{BAB 1}

\section{PENDAHULUAN}

\subsection{Latar Belakang}

Pada zaman yang modern ini karyawan dituntut untuk memiliki softskil dan hardskil yang mumpuni agar mampu bekerja dengan cepat demi tercapainya target dalam suatu produksi. Dalam hal ini perusahaan mengupayakan berbagai cara agar produktivitas karyawan bisa terus meningkat tanpa mengurangi kualitas produksinya. Salah satunya adalah dengan memenuhi kebutuhan karyawan sesuai dengan kebutuhannya, sehingga terjadi proses timbal balik saling menguntungkan antara kedua belah pihak tanpa ada yang merasa dirugikan. Produktivitas berarti kemampuan menghasilkan sesuatu. Sedangkan kerja berarti kegiatan melakukan sesuatu yang dilakukan untuk mencari nafkah mata pencaharian (Poerwadarminta, 1984: 70). Produktivitas adalah nilai output dalam hubungan dengan suatu kesatuan input tertentu. Peningkatan produktivitas yang berarti jumlah sumber daya yang digunakan dengan jumlah barang dan jasa yang diproduksi semakin meningkat dan membaik. Salah satu input yang digunakan untuk meningkatkan produktivitas adalah dengan membuat karyawan senang dan gembira yaitu dengan cara memberikan musik sebagai pengiring ketika bekerja sukamto (1995: 79). Dapat disimpulkan bahwa produktivitas kerja adalah kemampuan karyawan dalam berproduksi dibandingkan dengan input

yang digunakan, seorang karyawan dapat dikatakan produktif apabila mampu 
menghasilkan barang atau jasa sesuai dengan diharapkan dalam waktu yang singkat atau tepat.

Menurut penelitian yang telah dilakukan Ali Akbar (2007), mengenai system automatic music emotion classification menyatakan bahwa musik berkaitan erat dengan psikologi manusia. Kenyataan bahwa dapat terkait emosi atau mood tertentu adalah fakta yang umum diketahui dan tidak dapat dibantah. Peneliti peneliti experimental memperkuat pernyataan ini. Musik pengiring kerja dapat memberikan pengaruh positif terhadap aspek fisiologis, psikologis, dan perilaku pegawai yang sedang bekerja, sehingga diharapkan dapat meningkatkan semangat kerja pegawai/karyawan. Musik yang mengalun dapat menambah semangat kerja seseorang karena menimbulkan suasana yang gembira dan tidak membosankan (Nitisemito, 2002: 56). Penggunaan musik pada jam kerja ternyata berpengaruh positif terhadap semangat kerja dan peningkatan produksi. Bahkan penggunaan musikpun dapat menurunkan tingkat absensi dan mengurangi kelelahan dalam bekerja. Efektif tidaknya musik digunakan dalam jam kerja, bergantung pada jenis musik yang dimainkan. Oleh karena itu, penggunaan musik kerja perlu disesuaikan dengan kesukaan karyawan dan kondisi ruang kerja (Mangkunegaran, 2005: 107)

Home Industry Trio di desa Tegalwangi merupakan salah industri rumahan yang memproduksi bos/tromol becak dan produk produk yang lainya. Bos/tromol becak merupakan bagian tengah pada roda becak, biasanya paling sering digunakan pada roda becak bagian depan. Proses produksinya yaitu melalui tahapan pengecoran bahan material, bubut, bor, poles, cat yang dilanjutkan dengan pengemasan. Jumlah 
keseluruhan karyawan home industri Trio yaitu 48 orang yang seluruhnya terdiri dari pria usia antara 18-50 tahun. Untuk jumlah produksi tiap bagian memiliki target yang berbeda. Besar kecilnya target dilihat dari kondisi mesin dan tingkat kesulitan proses produksinya. Untuk proses membubut bagian badan bos/tromol becak satu karyawan bisa menghasilkan 40-50 psc/hari, proses mengebor ring satu karyawan bisa menghasilkan 50-60 pcs/hari, proses pengecoran bahan material satu karyawan bisa menghasilkan 100 pcs/hari, proses pemolesan satu karyawan bisa menghasilkan 100150 pcs/hari, untuk pengecatan dan pembungkusan 200 pcs/hari. Proses mengelas satu karyawan bisa menghasilkan 50-70 pcs/hari, dan untuk repair gerinda satu karyawan bisa menghasilkan 50-70 pcs/hari.

Dari berbagai proses tersebut sangat memakan banyak tenaga karena memang butuh konsentrasi yang tinggi untuk mengerjakannya, jika hilang konsentrasi sedikit saja bisa membahayakan karyawan itu sendiri. Dari proses tersebut mengakibatkan karyawan cepat lelah dan bosan karena prosesnya yang monoton. Untuk menambah atau meningkatkan semangat kerja dari para karyawan, maka cara terbaik adalah melalui musik. Karena dengan mendengarkan musik kesukaan atau musik penambah semangat maka semangat kerja dapat timbul kembali. Dalam hal ini pemilik industri rumahan menyediakan seperangkat sound system agar karyawannya bebas mendengarkan musik yang mereka sukai, tetapi kebanyakan dari karyawan lebih sering mendengarkan musik dangdut sebagai pengiring mereka bekerja.

Hal tersebutlah yang menjadi pendorong atau latar belakang peneliti untuk melakukan penelitian mengenai Hubungan Antara Kesenangan Mendengarkan Musik 
Dangdut Dengan Tingkat Produktivitas Karyawan Home Industry Trio Di Desa Tegalwangi Kabupaten Tegal.

\subsection{Identifikasi Masalah}

Berdasarkan latar belakang di atas, pengidentifikasian berdasarkan pada penelitian yang dilakukan oleh Ali Akbar (2007), mengenai system automatic music emotion classification menyatakan bahwa musik berkaitan erat dengan psikologi manusia. Bahwa mendengarkan musik yang disukai oleh seseorang mampu meningkatkan tingkat produktivtas, Musik pengiring kerja dapat memberikan pengaruh positif terhadap aspek fisiologis, psikologis, dan perilaku pegawai yang sedang bekerja, sehingga diharapkan dapat meningkatkan semangat kerja pegawai/karyawan. Musik yang mengalun dapat menambah semangat kerja seseorang karena menimbulkan suasana yang gembira dan tidak membosankan.

Mendengarkan musik dangdut sudah menjadi kebutuhan karyawan Home Industry Trio sehari-hari sebagai pengiring mereka bekerja. Adapun Menurut Sinungan (2000: 23) beberapa faktor yang mempengaruhi Produktivitas kerja secara umum yaitu:

(1) Kebutuhan manusia; yang meliputi: latar belakang kebudayaan dan pendidikan, kemampuan/bakat, sikap, minat atau kesenangan, pengalaman, umur (kadangkadang jenis kelamin) dari angkatan kerja; (2) Modal; yang terdiri dari modal tetap (mesin, gedung, alat-alat, volume dan standar), strukturnya, tehnologi, litbang, dan bahan baku (volume dan standar); (3) Metode atau proses baik tata ruang tugas, penanganan bahan baku penolong dan mesin, perencanaan dan pengawasan produksi, pemeliharan melalui pencegahan, teknologi yang memakai cara alternative;, 
(4) Produksi yang meliputi: kuantitas, kualitas, ruangan produksi, struktur campuran, dan 3 spesial produksi; (5) Lingkungan Organisasi (internal) berupa: organisasi dan perencanaan, sistem manajemen, kondisi kerja (fisik), iklim kerja (sosial), tujuan perusahaan dan hubungannya dengan tujuan lingkungan, sistem insentif, kebijaksanaan pearsonilia, gaya kepemimpinan dan ukuran perusahaan (ekonomi skala); (6) Lingkungan Negara (eksternal) seperti; kondisi ekonomi dan perdagangan stuktur sosial dan politik, struktur industri, tujuan pengembangan jangka panjang, pengakuan atau pengesahan, kebijakssanaan ekonomi pemerintah (perpajakan dan lain-lain), kebijakan tenaga kerja, energi, kebijakan pendidikan dan latihan, kondisi iklim dan geografis serta kebijakan perlindungan lingkungan; (7) Lingkungan Internasional (regional) yang terdiri dari: kondisi perdagangan dunia, masalah-masalah perdagangan internasional spesialisasi internasional, kebijakan migrasi tenaga kerja,dan standar tenaga kerja; (8) Umpan balik yaitu informasi yang ada hubungannya dengan timbal balik masukan (input) dan hasil (output) dalam perusahaan, antara perusahaan dengan ruang lingkup Negara (internasioanal).

\subsection{Pembatasan Masalah}

Berdasarkan identifikasi di atas maka penelitian ini hanya dibatasi pada:

1.3.1 Subjek penelitian yaitu hanya dalam lingkup karyawan Home Industry Trio Desa Tegalwangi Kabupaten Tegal

1.3.2 Objek penelitian yang di teliti adalah hubungan antara kesenangan mendengarkan musik dangdut dengan tingkat produktivitas karyawan Home Industry Trio Desa Tegalwangi Kabupaten Tegal. 


\subsection{Rumusan Masalah}

Dari uraian pembatasan masalah di atas maka dapat dirumuskan masalah yaitu sebagai berikut:

1.4.1 Adakah korelasi antara kesenangan mendengarkan musik dangdut terhadap tingkat produktivitas karyawan Home Industry Trio Desa Tegalwangi Kabupaten Tegal?

1.4.2 Adakah pengaruh kesenangan mendengarkan musik dangdut terhadap tingkat produktivitas karyawan Home Industry Trio di Desa Tegalwangi Kabupaten Tegal?

1.4.3 Seberapa besar kontribusi kesenangan mendengarkan musik dangdut terhadap tingkat produktivitas karyawan Home Industry Trio Desa Tegalwangi Kabupaten Tegal?

\subsection{Tujuan Penelitian}

Berdasarkan permasalahan yang telah dikemukakan di atas maka tujuan yang ingin dicapai dari penelitian ini adalah untuk mengetahui, mendeskripsikan, dan menganalisa:

1.5.1 Korelasi antara kesenangan mendengarkan musik dangdut terhadap tingkat produktivitas karyawan Home Industry Trio Desa Tegalwangi Kabupaten Tegal.

1.5.2 Pengaruh kesenangan mendengarkan musik dangdut terhadap tingkat produktivitas karyawan Home Industry Trio di Desa Tegalwangi Kabupaten Tegal. 
1.5.3 Kontribusi kesenangan mendengarkan musik dangdut terhadap tingkat produktivitas karyawan Home Industry Trio Desa Tegalwangi Kabupaten Tegal.

\subsection{Manfaat Penelitian}

Dengan adanya penelitian ini diharapakan dapat memperoleh manfaat sebagai berikut:

\subsubsection{Manfaat teoritis}

Penelitian ini membuahkan manfaat teoritis yaitu dapat memberikan sumbangan pemikiran dan tolak ukur kajian pada penelitian lebih lanjut dan menambah khasanah pengembangan pengetahuan mengenai hubungan antara kesenangan mendengarkan musik dengan tingkat produktivitas karyawan Home Industry Trio Desa Tegalwangi Kabupaten Tegal.

\subsubsection{Manfaat praktis}

Bagi peneliti, penelitian ini dapat memperkaya wawasan mengenai hubungan anatara kesenangan mendengarkan musik dangdut terhadap tingkat produktivitas karyawan

Bagi pembaca, hasil penelitian ini diharapkan dapat menambah informasi kepada pembaca tentang hubungan antara kesenangan mendengarkan musik dangdut dengan tingkat produktivitas karyawan Home Industry Trio Desa Tegalwangi Kabupaten Tegal. .

Bagi mahasiswa jurusan PSDTM UNNES, hasil penelitian ini dapat menambah khasanah alam dunia ilmu pengetahuan tentang hubungan antara kesenanngan 
mendengarkan musik dangdut dengan tingkat produktivitas karyawan sehingga bisa dijadikan referensi untuk penelitian berikutnya.

BAB 2 


\section{LANDASAN TEORI}

\subsection{Kajian Pustaka}

Penelitian tentang hubungan antara kesenangan mendengarkan musik bukan satu-satunya penelitian yang dilakukan penulis. Ada beberapa referensi yang menginspirasi penulis untuk melakukan penelitian ini. salah satu contohnya penelitian yang mempunyai hubungan yang sama dengan penelitian yang diambil oleh penulis dari beberapa sumber.

Sumber pertama adalah penelitian yang dilakukan oleh Dyah Fitriana Lukitasari (UNNES 2009) yang berjudul "Hubugan antara Kesenangan Bermain Musik dengan Hasil Belajar Seni Musik Siswa SMP Negeri 2 Ambarawa Tahun Ajaran 2008/2009”. Penelitian ini bertujuan untuk mengetahui adakah hubungan antara kesenangan bermain musik terhadap tingkat hasil belajar siswa. penelitian ini merupakan penelitian korelasi dengan pendekatan kuantitaif.

Sumber kedua adalah penelitian yang diilakukan oleh Fitria Yuniarti (UNNES 2009) yang berjudul "Hubungan antara Bakat Musik dengan Minat Siswa Kelas X Terhadap Ekstrakulikuler Band di SMA Negeri 2 Pekalongan”. Penelitian ini bertujuan untuk mengetahui adakah hubungan antara bakat dengan minat Siswa terhadap ekstrakulikuler Band. Penelitian ini merupakan penelitian deskriptif kuantitatif.

Sumber ketiga adalah penelitian yang dilakukan oleh Ika Prastiwi Utomo (UMS 2014) yang berjudul "Pengaruh Musik terhadap Semangat Kerja dan Produktivitas Tenaga Kerja dibagian Linting Rokok PT. Tjitoe Indonesia Tobako Surakarta". 
Penelitan ini bertujuan untuk mengetahui pengaruh musik terhadap tingkat semangat dan produktivitas karyawan. Penelitian ini menggunakan jenis penelitian survai analitik dengan pendekatan Cross Sectional dan jenis rancangan One group pre test and post test design.

\subsection{Pengertian Kesenangan Mendengarkan Musik Dangdut (X)}

Manusia di anugerahi lima panca indera oleh Tuhan untuk menjalankan aktifitas kehidupan sehari-harinya di dunia, salah satunya adalah telinga. Telinga merupakan organ tubuh manusia yang berfungsi sebagai indra pendengaran dan organ yang menjaga keseimbangan. Telinga juga merupakan organ yang berperan terhadap pendengaran kita akan suara atau bunyi, hal ini dapat terjadi karena telinga memiliki reseptor khusus yang berfungsi untuk mengenali getaran suara. Namun Telinga memiliki batasan frekuensi suara yang dapat didengar, yaitu yang frekuensinya $20 \mathrm{~Hz}$ - 20.000 Hz. Mendengar mempunyai makna dapat menangkap bunyi dengan telinga. Sadar atau tidak, kalau ada bunyi, alat pendengar kita akan menangkap atau mendengar bunyi-bunyi tersebut. Proses mendengar terjadi tanpa perencanaan tetapi datang secara kebetulan. Bunyi-bunyi yang hadir di telinga itu mungkin menarik perhatian, mungkin juga tidak.

"Kesenangan adalah kepuasan hati, kelegaan, kesukaan, kenikmatan, kenyamanan, kebahagiaan" (Depdikbud, 1991: 910). Kesenangan juga dapat diartikan sebagai kegemaran, kesukaan, dan hobi. Senang juga dapat diartikan puas dan lega, tanpa rasa susah dan kecewa, betah, berbahagia, tidak kurang suatu apapun dalam hidupnya, suka, gembira, sayang, dalam keadaan baik, mudah, praktis (Hoetomo, 2005: 
459) mengartikan senang yaitu merasa puas, lega, tidak susah, tidak kecewa, betah, berbahagia, tidak ada sesuatu yang menysahkan, tidak kurang suatu apapun, suka, mudah, serba mudah, tak berabai, praktis, dalam keadaan baik, sehat nyaman dan sebagainya. Sedangkan kesenangan adalah kepuasan hati, kelegaan, kenikmatan, kenyamanan, kebahagiaan.

Dalam apresiasi musik, seseorang dituntut untuk mendengarkan musik secara nyata, dan itu membutuhkan suatu kerja keras. Tanpa mau mendengarkan secara seksama dengan disertai pemahaman terhadap teori musik, suatu bentuk apresiasi musik itu tidak akan terbentuk. Ada beberapa cara mendengarkan, yaitu mendengarkan secara pasif, mendengarkan secara menikmati, mendengarkan secara emosional, dan mendengarkan secara perseptif (Miller, 1958: 9-11).

Mendengarkan secara pasif. Cara mendengarkan musik secara pasif merupakan suatu cara mendengarkan musik secara tidak sungguh-sungguh. Dalam hal ini musik hanya dijadikan suatu latar belakang kegiatan lain. Misalnya, ketika kita pergi ke perpustakaan atau ke toko buku, Anda menemukan buku yang membuat ingin membacanya serta melanjutkan paragraf demi paragraf. Pada saat Anda sedang menikmati membaca buku, perpustakaan atau toko buku yang Anda kunjungi tengah memutarkan lagu-lagu yang kian membuat Anda hanyut dalam bacaan yang sedang Anda baca. Biasanya lagu-lagu yang diperdengarkan adalah lagu-lagu instrumental yang menenangkan dengan tempo tak begitu cepat, sehingga membuat para pembaca betah berlama-lama dalam membaca buku tersebut. Musik instrumental tidak akan mengganggu kegiatan seseorang dalam membaca buku, karena meskipun membaca 
buku dan mendengarkan musik dilakukan secara bersamaan, tetapi bagian otak yang digunakan berbeda. Dalam hal ini, dapat dikatakan bahwa alunan musik hanya sebagai latar belakang kegiatan membaca buku, bukan menjadi kegiatan utama. Berbeda ketika seseorang membaca buku dibarengi dengan mendengarkan lagu yang disertai dengan lirik, maka konsentrasi orang tersebut cenderung terpecah karena otak orang tersebut berusaha memproses dua hal yaitu memahami lirik serta memahami apa yang sedang dibaca. Mendengarkan musik secara pasif merupakan suatu cara mendengarkan musik sebagai latar belakang kegiatan lain yang lebih utama, dengan kata lain, cara mendengarkan musik secara pasif ini bukanlah cara mendengarkan musik yang menuntut konsentrasi penuh untuk bisa disebut dengan istilah mengapresiasi musik.

Mendengarkan musik secara menikmati merupakan cara mendengarkan musik yang lebih baik dibandingkan mendengarkan musiik secara pasif. Karena, mendengarkan musik secara menikmati membutuhkan sebuah perhatian yang lebih besar dibandingkan mendengarkan musik secara pasif. Dalam mendengarkan musik secara pasif, mendengarkan musik hanyalah sebuah kegiatan yang melatarbelakangi kegiatan lain yang lebih inti atau penting. Sedangkan mendengarkan musik secara menikmati adalah suatu upaya mendengarkan musik yang dijadikan kegiatan tunggal tanpa disertai kegiatan lain, sehingga mendengarkan musik secara menikmati membutuhkan perhatian lebih besar dibandingkan mendengarkan musik secara pasif. Mendengarkan musik secara menikmati tak begitu membutuhkan pengetahuan teori musik yang mumpuni, karena cara mendengarkan musik secara menikmati ini hanyalah sebuah cara mendengarkan musik yang menuntut hati serta pikiran seseorang nyaman 
dan suka ketika mendengarkan musik tersebut sehingga dapat menikmati dengan baik, tanpa adanya kegiatan lain. Dalam cara mendengarkan musik secara menikmati, seseorang akan menemukan nada-nada musikal dalam sebuah lagu yang sedang didengarkan yang mampu membuatnya merasa dimanjakan. Dengan cara mendengarkan ini, seseorang baru bisa disebut menyukai musik yang sedang didengarkan, dengan dimunculkan oleh gejala-gejala nyaman oleh sensasi-sensasi nada-nada yang didengarkan. Meskipun cara mendengarkan musik secara menikmati telah membuat diri merasa dimanjakan oleh sensasi-sensasi nada-nada dari musik yang didengarkan sehingga sangat merasa menikmatinya, namun cara mendengarkan musik secara menikmati ini belum bisa mencapai apa yang disebut dengan istilah apresiasi musik.

Mendengarkan musik secara emosional merupakan cara mendengarkan musik sesuai gejolak yang timbul terhadap diri. Ketika mendengarkan sebuah komposisi musik, seseorang yang mendengarkan musik dengan cara ini akan merasa mendapatkan sensasi-sensasi emosional yang ditimbulkan. Misalnya, ketika seseorang sedang sedih kemudian mendengarkan lagu-lagu sendu bahkan berisikan lirik-lirik yang sesuai dengan kesedihannya, maka orang tersebut akan mengalami senasi-sensasi emosional yang ditimbulkan oleh lagu-lagu yang didengarkan. Begitu pula sebaliknya, ketika seseorang sedang mengalami kebahagiaan dalam hidupnya kemudian mendengarkan lagu-lagu yang bertemakan kebahagian terlebih berisikan lirik-lirik yang sesuai dengan apa yang sedang dialami, maka seseorang tersebut akan mengalami sensasi-sensasi emosional oleh lagu yang telah didengarkan. Atau bisa saja mendengarkan musik 
secara emosional dapat didefinisikan ketika mendengarkan sebuah komposisi musik, orang tersebut akan teringat dengan masa lalunya yang mengakibatkan gejolak emosi dalam dirinya. Dalam mendengarkan musik secara emosional tidak dibutuhkan pengetahuan teori musik yang baik serta latihan-latihan secara berkesinambungan. Mendengarkan musik secara emosional ini timbul secara alami, sehingga sensasisensasi emosional yang ditimbulkan oleh jiwa terjadi karena perasaan tertentu. Cara mendengarkan musik secara emosional ini belum dapat dikatakan sebagai cara mendengarkan musik yang baik sehingga belum mencapai apa yang disebut dengan istilah apresiasi musik.

Mendengarkan musik secara perseptif merupakan cara mendengarkan musik yang menuntut konsentrasi serta pemahaman mengenai apa yang sedang didengarkan. Mendengarkan musik secara perseptif adalah cara mendengarkan musik yang lebih baik dibandingkan dengan cara mendengarkan musik secara pasif, mendengarkan musik secara menikmati maupun mendengarkan musik secara emosional. Cara mendengarkan musik inilah yang dapat dikatakan dengan istilah apresiasi musik, karena dengan cara mendengar musik secara perseptif menuntut untuk memahami benar mengenai apa yang sedang didengarkan sehingga paham apa yang sedang diapresiasi. Tidak lupa, mendengarkan musik secara perseptif menuntut seseorang menguasai kemampuan teori musik yang baik agar dapat memahami apa yang sedang didengar ketika sedang mendengarkan sebuah komposisi musik. Dari beberapa cara mendengar tersebut, belum tentu seorang apresiator dapat melakukan salah satu cara mendengar tersebut secara murni. Terkadang mereka mendengarkan musik dengan 
cara yang berubah-ubah, terkadang secara pasif, kemudian bisa menikmati setelah benar-benar memerhatikan apa yang didengar, atau mungkin beberapa nada mampu menyentuh sanubarinya sehingga muncullah gejolak-gejolak emosional, dan kemudian dengan konsentrasi penuh berusaha memahami apa yang sedang didengarkan dengan catatan telah menguasai teori musik dengan baik. Dengan cara bagaimanapun seseorang medengarkan sebuah komposisi musik, cara mendengarkan musik secara perseptiflah yang menuntut kemampuan teori musik yang baik serta konsentrasi penuh agar pemahaman mengenai musik yang didengarkan mampu tercapai dengan baik. Cara mendengarkan musik secara perseptif tersebut dapat dikatakan telah mencapai tujuan awal, yaitu apresiasi musik, yang secara tidak sadar atau tidak langsung menambah pengalaman musikal seseorang.

Musik adalah suatu hasil karya seni berupa bunyi dalam bentuk lagu atau komposisi yang mengungkapkan pikiran dan perasaan penciptanya melalui unsurunsur pokok musik yaitu irama, melodi, harmoni, dan bentuk atau struktur lagu serta ekspresi sebagai suatu kesatuan. (Jamalus, 1988: 1). Musik merupakan seni yang timbul dari perasaan atau pikiran manusia sebagai pengungkapan ekspresi diri, yang diolah dalam suatu nada-nada atau suara-suara yang harmonis. Jika musik diartikan sebagai ungkapan sederhana dari suasana hati jiwa atau respon harafiah terhadap peristiwa dari diri pribadi komponis, diperlukan informasi ataupun referensi yang cukup agar kita dapat menarik hubungan langsung antara kehidupan dengan karyanya.

Musik Seni merupakan pengelompokan musik ke arah Musik klasik dan musikmusik sejenis yang dinilai secara tingkat nilai sejarahnya selain dari nilai seninya. 
Musik jenis ini lebih digunakan untuk merujuk jenis-jenis musik yang sangat patuh kepada teori-teori musik dan biasanya sukar untuk dipahami orang awam (kecuali yang sudah mulai digabung dengan gaya Musik Populer). Diantaranya yaitu musik klasik, musik popular, jazz, gospel, blues, keroncong, dan dangdut.

Dangdut merupakan hasil perpaduan antara musik India dengan musik Melayu, musik ini kemudian berkembang dan menampilkan cirinya yang khas dan berbeda dengan musik akarnya. Ciri khas musik ini terletak pada pukulan alat musik tabla (sejenis alat musik perkusi yang menghasilkan bunyi ndut). Selain itu, iramanya ringan, sehingga mendorong penyanyi dan pendengarnya untuk mengerakkan anggota badannya. Lagunya pun mudah dicerna, sehingga tidak susah untuk diterima masyarakat. Dangdut merupakan salah satu dari genre seni musik yang berkembang di Indonesia. Bentuk musik ini berakar dari musik Melayu pada tahun 1940-an. Dalam evolusi menuju bentuk kontemporer sekarang masuk pengaruh unsur-unsur musik India (terutama dari penggunaan tabla) dan Arab (pada cengkok dan harmonisasi). Perubahan arus politik Indonesia di akhir tahun 1960-an membuka masuknya pengaruh musik barat yang kuat dengan masuknya penggunaan gitar listrik dan juga bentuk pemasarannya. Sejak tahun 1970-an dangdut boleh dikatakan telah matang dalam bentuknya yang kontemporer. Sebagai musik populer, dangdut sangat terbuka terhadap pengaruh bentuk musik lain, mulai dari keroncong, langgam, degung, gambus, rock, pop, bahkan house musik. Penyebutan nama "dangdut" merupakan onomatope dari suara permainan tabla (dalam dunia dangdut disebut gendang saja) yang khas dan didominasi oleh bunyi dang dan ndut. Nama ini sebetulnya adalah sebutan sinis dalam 
sebuah artikel majalah awal 1970-an bagi bentuk musik melayu yang sangat populer di kalangan masyarakat kelas pekerja saat itu.

Dangdut kontemporer telah berbeda dari akarnya, musik Melayu, meskipun orang masih dapat merasakan sentuhannya. Orkes Melayu (biasa disingkat OM, sebutan yang masih sering dipakai untuk suatu grup musik dangdut) yang asli menggunakan alat musik seperti gitar akustik, akordeon, rebana, gambus, dan suling, bahkan gong. Pada tahun 1950-an dan 1960-an banyak berkembang orkes-orkes Melayu di Jakarta yang memainkan lagu-lagu Melayu Deli dari Sumatera (sekitar Medan). Pada masa ini mulai masuk eksperimen masuknya unsur India dalam musik Melayu. Perkembangan dunia sinema pada masa itu dan politik anti-Barat dari Presiden Sukarno menjadi pupuk bagi grup-grup ini. Dari masa ini dapat dicatat nama-nama seperti P. Ramlee (dari Malaya), Said Effendi (dengan lagu Seroja), Ellya (dengan gaya panggung seperti penari India, sang pencipta Boneka dari India), Husein Bawafie (salah seorang penulis lagu Ratapan Anak Tiri), Munif Bahaswan (pencipta Beban Asmara), serta M. Mashabi (pencipta skor film "Ratapan Anak Tiri" yang sangat populer di tahun 1970-an). Gaya bermusik masa ini masih terus bertahan hingga 1970an, walaupun pada saat itu juga terjadi perubahan besar di kancah musik Melayu yang dimotori oleh Soneta Group pimpinan Rhoma Irama. Beberapa nama dari masa 1970an yang dapat disebut adalah Mansyur S., Ida Laila, A. Rafiq, serta Muchsin Alatas. Populernya musik Melayu dapat dilihat dari keluarnya beberapa album pop Melayu oleh kelompok musik pop Koes Plus di masa jayanya. 
Dangdut modern, yang berkembang pada awal tahun 1970-an sejalan dengan politik Indonesia yang ramah terhadap budaya Barat, memasukkan alat-alat musik modern Barat seperti gitar listrik, organ elektrik, perkusi, terompet, saksofon, obo, dan lain-lain untuk meningkatkan variasi dan sebagai lahan kreativitas pemusikpemusiknya. Mandolin juga masuk sebagai unsur penting. Pengaruh rock (terutama pada permainan gitar) sangat kental terasa pada musik dangdut. Tahun 1970-an menjadi ajang 'pertempuran' bagi musik dangdut dan musik rock dalam merebut pasar musik Indonesia, hingga pernah diadakan konser 'duel' antara Soneta Group dan God Bless. Praktis sejak masa ini musik Melayu telah berubah, termasuk dalam pola bisnis bermusiknya. Pada paruh akhir dekade 1970-an juga berkembang variasi "dangdut humor" yang dimotori oleh OM Pancaran Sinar Petromaks (PSP). Orkes ini, yang berangkat dari gaya musik melayu deli, membantu diseminasi dangdut di kalangan mahasiswa. Subgenre ini diteruskan, misalnya, oleh OM Pengantar Minum Racun (PMR) dan, pada awal tahun 2000-an, oleh Orkes Pemuda Harapan Bangsa (PHB) (Wikipedia, pengertian musik dangdut)

Berdasarkan teori di atas maka peneliti dapat menyimpulkan mengenai kesenangan mendengarkan musik dangdut adalah kegemaran, kenikmatan hati yang dirasakan oleh seseorang dalam mendengarkan, mengahayati, meresapi sebuah musik jenis dangdut yang bertujuan untuk memperoleh rasa kepuasan hati agar menjadi termotivasi. Motivasi dalam hal ini adalah diwujudkan dalam bentuk usaha untuk mengalihkan perhatian dari rasa bosan dan kelelahan saat bekerja menjadi lebih semangat sehingga target produksi bisa tercapai dengan baik. 


\subsection{Pengertian Produktivitas Karyawan (Y)}

Produktivitas berarti kemampuan menghasilkan sesuatu. Sedangkan kerja berarti kegiatan melakukan sesuatu yang dilakukan untuk mencari nafkah mata pencahrian (Poerwadarminta, 1984: 70). Produktivitas kerja adalah kemampuan menghasilkan suatu kerja yang lebih banyak dari pada ukuran biasa yang telah umum. (The Liang Gie, 1981: 3).

Pengukuran produktivitas kerja pada dasarnya digunakan untuk mengetahui sejauh mana tingkat efektivitas dan efisiensi kerja karyawan dalam menghasilkan suatu hasil. Dalam usaha untuk dapat mengukur tingkat kemampuan karyawan dalam mencapai sesuatu hasil yang lebih baik dan ketentuan yang berlaku (kesuksesan kerja). Tingkat produktivitas kerja karyawan yang dapat diukur adalah:

1. Penggunaan waktu kerja sebagai alat ukur produktivitas kerja karyawan meliputi: (1) Kecepatan waktu kerja, (2) Penghematan waktu kerja, (3) Kedisiplinan waktu kerja, (4) Tingkat absensi.

2. Output yaitu hasil produksi karyawan yang diperoleh sesuai produk yang diinginkan perusahaan. Pengukuran produktivitas digunakan sebagai sarana untuk menganalisa dan mendorong dan efisiensi produksi. Manfaat lain adalah untuk menentukan target dan kegunaan praktisnya sebagai patokan dalam pembayaran upah karyawan. Tujuan pengukuran produktivitas adalah membandingkan hasil hal-hal berikut: (1) Pertambahan produksi dari waktu ke waktu; (2) Pertambahan pendapatan dari waktu ke waktu; (3) Pertambahan kesempatan kerja dari waktu ke waktu; (4) Jumlah hasil 
sendiri dengan orang lain; (5) Komponen prestasi utama sendiri dengan komponen prestasi utama orang lain (Rusli Syarif, 1991:7).

Alat pengukuran produktivitas karyawan perusahaan dibedakan menjadi dua macam, yaitu: (1) Physical productivity adalah produktivitas secara kuantitatif seperti ukuran (Size) panjang, berat, banyaknya unit, waktu dan banyaknya tenaga kerja; (2) Value productivity adalah ukuran produktivitas dengan menggunakan nilai uang yang dinyatakan dalam rupiah, yen, won, dollar (J. Ravianto, 1986: 21).

Pengukuran produktivitas ini mempunyai peranan yang sangat penting untuk mengetahui produktivitas kerja sesuai dengan yang diharapkan perusahaan. Dalam penelitian ini yang menjadi pengukuran produktivitas kerja yaitu penggunaan waktu dan hasil kerja atau out put. Berdasarkan pendapat di atas maka pengukuran produktivitas dapat dilihat dari dua komponen yaitu: (1) Efisiensi kerja, efisiensi kerja karyawan dapat dilihat dari ketercapaian terget, ketepatan waktu, ketepatan masuk kerja; (2) Produksi, produksi kerja yang dihasilkan karyawan dapat dilihat dari kualitas, peningkatan setiap bulan dan persentase kesesuaian dengan harapan perusahaan.

Karyawan merupakan aset terpenting yang memiliki pengaruh sangat besar terhadap kesuksesan sebuah perusahaan. Tanpa mesin canggih, perusahaan dapat terus beroperasi secara manual, akan tetapi tanpa karyawan, perusahaan tidak akan dapat berjalan sama sekali. karyawan dapat diartikan sebagai setiap orang yang memberikan jasa kepada perusahaan ataupun organisasi yang membutuhkan jasa tenaga kerja, yang mana dari jasa tersebut, karyawan akan mendapatkan balas jasa berupa gaji dan kompensasi-kompensasi lainnya. 
Karyawan merupakan setiap penduduk yang masuk ke dalam usia kerja (berusia di rentang 15 hingga 64 tahun), atau jumlah total seluruh penduduk yang ada pada sebuah negara yang memproduksi barang dan jasa jika ada permintaan akan tenaga yang mereka produksi, dan jika mereka mau berkecimpung/berpartisipasi dalam aktivitas (Subri, 2002: 57). Sedangkan menurut Hasibuan (2002: 160) Karyawan adalah setiap orang yang menyediakan jasa (baik dalam bentuk pikiran maupun dalam bentuk tenaga) dan mendapatkan balas jasa ataupun kompensasi yang besarannya telah ditentukan terlebih dahulu.

Jika dikelompokkan berdasarkan statusnya, karyawan dalam perusahaan dapat dibagi menjadi dua jenis kelompok karyawan yaitu karyawan tetap dan karyawan tidak tetap.

\section{Karyawan Tetap}

Karyawan tetap merupakan karyawan yang telah memiliki kontrak ataupun perjanjian kerja dengan perusahaan dalam jangka waktu yang tidak ditetapkan (permanent). Karyawan tetap biasanya cenderung memiliki hak yang jauh lebih besar dibandingkan dengan karyawan tidak tetap. Selain itu, karyawan tetap juga cenderung jauh lebih aman (dalam hal kepastian lapangan pekerjaan) dibandingkan dengan karyawan tidak tetap.

\section{Karyawan Tidak Tetap}

Karyawan tidak tetap merupakan karyawan yang hanya dipekerjakan ketika perusahaan membutuhkan tenaga kerja tambahan saja. Karyawan tidak tetap biasanya dapat diberhentikan sewaktu-waktu oleh perusahaan ketika perusahaan sudah tidak 
membutuhkan tenaga tambahan lagi. Jika dibandingkan dengan karyawan tetap, karyawan tidak tetap cenderung memiliki hak yang jauh lebih sedikit dan juga cenderung sedikit tidak aman (dalam hal kepastian lapangan pekerjaan).

Berdasarkan beberapa teori di atas maka peneliti dapat menyimpulkan mengenai tingkat produktivitas karyawan yaitu kemampuan seseorang untuk menghasikan sesuatu untuk mencapai atau meningkatkan suatu target yang dapat dinilai dari kinerja yang meliputi: tingkat absensi, kedisiplinan kerja, pencapaian atau peningkatan target produksi, dan kualitas hasil produksi. Sehingga bisa tercapai hubungan timbal balik antara kedua belah pihak tanpa ada yang merasa dirugikan.

\subsection{Kerangka Berfikir}

2.4.1 Hubungan Antara Kesenangan Mendengarkan Musik Dangdut dengan Tingkat Produktivitas Karyawan Home Industry Trio di Desa Tegalwangi Kabupaten Tegal.

Mendengarkan merupakan kegiatan yang dilakukan secara sengaja oleh semua manusia untuk menangkap, memahami, mengingat, dan mengindahkan segala sesuatu yang di dengarnya, sedangkan musik merupakan ilmu tentang bunyi. Melalui pendengaran, musik dapat dimengerti dan dirasakan makna dan kesan yang terkandung didalamnya. Mendengarkan musik merupakan kegiatan wajib yang sering dilakukan karyawan Home Industry Trio menjalani aktifitas ketika mereka sedang bekerja. Hal itu dapat diamati dari kepuasan hati, kegemaran, dan kenikmatan pada saat mereka bekerja sambil mendengarkan musik. 
Karyawan Home Industry Trio Desa Tegalwangi mayoritas suka mendengarkan musik ketika sedang melakukan pekerjaannya. Mereka percaya, pada saat melakukan pekerjaan yang membutuhkan konsentrasi, membosankan, monoton, dan melelahkan, butuh sesuatu yang bisa memacunya agar pekerjaan dapat tetap berjalan dengan lancar tanpa mengurangi produktivitas.

2.4.2 Kontribusi Antara Kesenangan Mendengarkan Musik Dangdut dengan Tingkat Produktivitas Karyawan Home Industry Trio di Desa Tegalwangi Kabupaten Tegal.

Tingkat kesenangan karayawan mendengarkan musik pada saat mereka bekerja bisa meningkatkan semangat yang bisa berpengaruh pada tingkat tercapainya target produksi di Home Industry Trio. Dalam hal ini musik yang paling disukai oleh karyawan Home Industry Trio yaitu musik dangdut. Alasannya yaitu karena menurut mereka musik dangdut cenderung lebih mudah diterima, liriknya sederhana, iramanya yang menghentak hentak, dan musiknya yang dinamis serta mudah di pahami bisa memunculkan rasa semangat bekerja pada saat mendengarkannya. Dengan adanya semangat dalam melakukan pekerjaan akan mempengaruhi kualitas pekerjaannya. Mendengarkan musik dangdut merupakan upaya yang dilakukan karyawan Home Industry Trio untuk meningkatkan semangat kerja sehingga karyawan tidak cepat bosan dan kelelahan. 
2.4.2 Pengaruh Antara Kesenangan Mendengarkan Musik Dangdut dengan Tingkat Produktivitas Karyawan Home Industry Trio di Desa Tegalwangi Kabupaten Tegal.

Kebiasaan mendengarkan musik dangdut yang dilakukan karyawan Home Industry Trio sebagai pengiring mereka bekerja sangatlah berpengaruh pada tingkat produktivitas, karena dengan mendengarkan musik dangdut bisa memunculkan rasa semangat bekerja, kemudian karyawan juga tidak merasa terbebani oleh target target yang harus di capai dalam suatu produksi karena melakukan pekerjaan dengan mendengarkan musik yang mereka sukai. Dari perasaan suka tersebut akan berdampak positif pada kegiatan produksi di Home Industry Trio Desa Tegalwangi dan juga akan sangat berpengaruh pada tingkat produktivitas karyawan itu sendiri sehingga target target yang di harapkan bisa tercapai dengan baik.

\subsection{Hipotesis Penelitian}

Hipotesis yaitu jawaban sementara terhadap rumusan masalah penelitian. Dikatakan sementara karena jawaban yang diberikan baru didasarkan pada teori dan belum menggunakan fakta (Arikunto, 2013: 110). Oleh karena itu, setiap penelitian yang dilakukan memiliki suatu hipotesis atau jawaban sementara terhadap penelitian yang akan dilakukan. Dari hipotesis tersebut akan dilakukan penelitian lebih lanjut untuk membuktikan apakah hipotesis tersebut benar adanya atau tidak benar.. Adapun hipotesis dalam penelitian ini adalah adanya korelasi antara kesenangan mendengarkan musik dangdut dengan tingkat produktivitas karyawan Home Industry Trio Desa 
Tegalwangi Kabupaten Tegal, yang merupakan korelasi dan variabel yang telah ditentukan.

Secara teknis produktivitas adalah suatu perbandingan antara hasil yang dicapai (out put) dengan keseluruhan sumber daya yang diperlukan (in put). Produktivitas mengandung pengertian perbandingan antara hasil yang dicapai dengan peran tenaga kerja persatuan waktu (Riyanto, 1986: 22). Tingkat produktivitas yang diukur adalah tingkat produktivitas karyawan Home Industry Trio.

Tingkat produktivitas merupakan usaha yang dilakukan oleh karyawan untuk meningkatkan kualitas produksi yang dapat diukur dari kinerja dan pencapaian target yang optimal sesuai dengan kriteria penilaian dari pemimpin atau pemilik Home Industry Trio melalui lembar penilaian kinerja karyawan. Sedangkan untuk mengukur tingkat kesenangan karayawan dalam mendengarkan musik dangdut sebagai pengiring kerja dapat dilaksanakan dengan memberikan angket yang dibuat oleh peneliti kepada karyawan yang bersangkutan.

Adapun hipotesis dalam penelitian ini adalah sebagai berikut :

\section{Hipotesis 1}

Ho: Tidak terdapat korelasi positif dan signifikan antara kesenangan mendengarkan musik terhadap tingkat produktivitas

Ha: Terdapat korelasi positif dan signifikan antara kesenangan mendengarkan musik terhadap tingkat produktivitas

\section{Hipotesis 2}


Ho: tidak ada pengaruh positif dan signifikan antara kesenangan mendengarkan musik terhadap tingkat produktivitas

Ha: ada pengaruh positif dan signifikan antara kesenangan mendengarkan musik terhadap tingkat produktivitas

\section{BAB 3}

\section{METODE PENELITIAN}

\subsection{Pendekatan Penelitian}


Penelitian yang digunakan adalah penelitian korelasi dengan pendekatan kuantitatif. "Penelitian korelasi yaitu hubungan antara dua variabel (Hadi, 2015; 250)". Penelitian korelasi yaitu suatu penelitian untuk mengetahui hubungan dan tingkat hubungan antara dua variabel atau lebih tanpa ada upaya untuk mempengaruhi variabel tersebut sehingga tidak terdapat manipulsi variabel (Faenkel dan Wallen, 2008: 328). Dalam penelitian ini yang dimaksud timbal balik adalah antara kesenangan mendengarkan musik dangdut dengan tingkat produktivitas karyawan Home Industry Trio Desa Tegalwangi Kabupaten Tegal, yang merupakan korelasi dua variabel yang telah ditentukan.

Sedangkan dalam penelitian ini pendekatan yang penulis gunakan adalah kuantitatif, sehingga setelah data terkumpul, penulis mengolah dan menganalisa secara asosiasi dengan mengkorelasikan variabel $\mathrm{X}$ yaitu kesenangan mendengarkan musik dangdut dengan variabel Y yaitu tingkat produktivitas.

\subsection{Tempat dan Waktu Penelitian}

Peneliti melakukan penelitian mengenai hubungan antara kesenangan mendengarkan musik dangdut dengan tingkat produktivitas karyawan di Home Industry Trio Desa Tegalwangi Kabupaten Tegal dimulai pada bulan Februari sampai dengan bulan Maret 2016.

\subsection{Populasi dan Sampel Penelitian}

\subsubsection{Populasi}

Menurut (Nawawi, 2001: 141) populasi adalah keseluruhan objek penelitian yang dapat terdiri dari manusia, benda-benda, hewan, tubuh-tumbuhan, gejala-gejala, nilai 
tes atau peristiwa-peristiwa sebagai sumber data yang memiliki karakteristik tertentu didalam suatu penelitian. Sedangakan menurut Arikunto (2013: 173). Populasi adalah keseluruhan subjek penelitian. Adapun yang menjadi populasi adalah seluruh karyawan Home Industry Trio Desa Tegalwangi Kabupaten Tegal yang berjumlah 58 orang.

\subsubsection{Sampel}

"Sampel adalah sebagian atau wakil populasi yang diteliti (Arikunto, 2013: 174)". Dalam pengambilan sampel, menurut Arikunto (2013: 177) jika jumlah subjeknya besar dapat diambil antara 10\%-15\% atau 20\%-25\% atau lebih, tergantung setidak tidaknya dari: (1) Kemampuan peneliti dilihat dari waktu, tenaga dan dana, (2) Sempit luasnya wilayah pengamatan dari setiap suubjek, karena hal ini menyangkut banyak sedikitnya data, (3) Besar kecilnya resiko yang ditanggung oleh peneliti. Untuk penelitian yang resikonya besar, tentu saja jika sampel besar, hasilnya akan lebih baik.

Teknik pengambilan sampel yang digunakan dalam penelitian ini adalah teknik random sampling. "Teknik random sampling adalah pengambilan sampel dari populasi secara random atau tanpa pandang bulu (Hadi, 2015: 193)". Dalam teknik ini penulis memberikan hak yang sama kepada setiap subyek untuk memperoleh kesempatan dipilih menjadi sampel. Sampel diambil secara acak dari keseluruhan karyawan Home Industry Trio, terpilihlah 30 karyawan sebagai sampel dalam penelitian ini.

\subsection{Variabel Penelitian}

"Variabel adalah obyek penelitian yang bervariasi atau apa yang menjadi titik perhatian (Arikunto, 2013: 161)”. Sedangkan variabel dalam penelitian yang berjudul 
Hubungan mendengarkan musik dangdut dengan tingkat produktifitas karyawan Home Industry Trio Desa Tegalwangi Kabupaten Tegal yaitu :

\subsubsection{Variabel Bebas $(X)$}

Variabel bebas atau dalam bahasa inggris independent variable ialah variabel yang menyebabkan timbulnya atau berubahnya dependent variable atau variabel terikat (Sugiyono, 1993: 3). Variabel bebas dalam penelitian ini adalah kesenangan mendengarkan musik dangdut karyawaan Home Industry Trio Desa Tegalwangi Kabupaten Tegal.

\subsubsection{Variabel Terikat $(\mathbf{Y})$}

Variabel terikat atau dependent variabel adalah variabel yang dipengaruhi atau yang menjadi akibat karena adanya variabel bebas (Sugiyono, 1993: 3). Variabel terikat pada penelitian ini adalah tingkat produktivitas karyawan Home Industry Trio Desa Tegalwangi Kabupaten Tegal. Selanjutnya hubungan kedua variabel tersebut dapat digambarkan sebagai berikut:

Variabel bebas $\quad$ Variabel Terikat

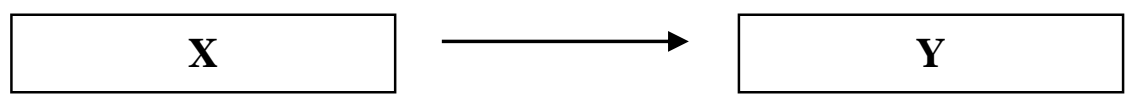

Keterangan:

$\mathrm{X}=\quad$ Kesenangan mendengarkan musik dangdut

$\mathrm{Y}=$ Tingkat produktivitas karyawan Home Industry Trio Desa Tegalwagi

Kabupaten Tegal

\subsection{Definisi Operasional}


Pada pembahasan tentang penelitian ini, perlu dijelaskan pengertian operasional hal-hal yang berkaitan dengan variabel penelitian agar tidak terjadi kesalahpahaman atau kerancuan terhadap arti dan maksud dari kedua variabel pada penelitian ini, maka dalam definisi operasional ini dijelaskan arti dan maksud dari kedua variabel tersebut, yaitu:

\subsubsection{Kesenangan mendengarkan musik dangdut}

Mendengarkan Musik Dangdut adalah kesenangan atau kebiasaan karyawan Home Industry Trio Desa Tegalwangi Kabupaten Tegal sebagai pengiring pada saat mereka sedang bekerja. Jam kerja di Home Industry Trio dimulai dari pukul 08.00 sampai pukul 16.00 WIB atau 8 jam/hari. Saat memulai bekerja mereka selalu menyalakan musik terlebih dahulu sebagai pengiring kegiatan produksi, dan baru akan mematikannya pada saat jam istirahat, kemudian akan menyalakannya kembali ketika kegiatan produksi dimulai hingga jam kerja berahkir. Jadi para karyawan mendengarkan musik selama 7 jam/hari atau $88 \%$ dari jam kerja. Kebiasaan ini dilakukan karyawan untuk menghilangkan rasa bosan dan meningkatkan semangat pada saat sedang bekerja. Hal ini dapat diamti dari kegemaran, kepuasan hati, kenikmatan, dan motivasi.

\subsubsection{Tingkat produktivitas Karyawan Home Industri Trio}

Produktivitas adalah kemampuan menghasilkan suatu kerja yang lebih banyak dari pada ukuran biasa yang telah umum, Pengukuran produktivitas kerja pada dasarnya digunakan untuk mengetahui sejauh mana tingkat efektivitas dan efisiensi 
kerja karyawan dalam menghasilkan suatu hasil. Dalam usaha untuk dapat mengukur tingkat kemampuan karyawan dalam mencapai sesuatu hasil yang lebih baik dan ketentuan yang berlaku (kesuksesan kerja). Dalam hal ini penulis memberikan hak sepenuhnya kepada pimpinan atau pemilik Home Industry Trio untuk menilai kinerja produktivitas karyawannya dengan sebaik baiknya. Hal ini dapat dinilai dari tingkat absensi, kedisiplinan kerja, pencapaian atau peningkatan target produksi, dan kualitas hasil produksi.

\subsection{Teknik pengumpulan data}

Dalam penelitian ini, penulis menggunakan metode penelitian data sebagai berikut:

\subsubsection{Angket}

Angket adalah salah satu teknik pengumpulan data yang berbentuk kumpulan pertanyaan (Hadeli, 2006: 75). Angket disini digunakan sebagai metode untuk memperleh informasi tentang kesenangan karyawan Home Industry Trio dalam mendengarkan musik dangdut sebagai pengiring bekerja.

Kisi-kisi angket mengenai kesenangan mendengarkan musik dangdut sebagai pengiring kerja yaitu:

\section{Tabel 3.1}

\section{Kisi kisi angket kesenangan mendengarkan musik dangdut}

\begin{tabular}{|l|c|c|c|}
\hline \multirow{2}{*}{ No } & \multirow{2}{*}{ Indikator } & \multicolumn{2}{|c|}{ Butir pertanyaan } \\
\cline { 3 - 4 } & & $(+)$ & $(-)$ \\
\hline
\end{tabular}




\begin{tabular}{|l|l|c|c|}
\cline { 3 - 4 } 1 & Kegemaran & 1,2 & 3,4 \\
\hline 2 & Kepuasan Hati & 5,6 & 7,8 \\
\hline 3 & Kenikmatan & 9,10 & 11,12 \\
\hline 4 & Motivasi & 13,14 & 15,16 \\
\hline \multicolumn{2}{|c}{ Jumlah pertanyaan } & 16 \\
\hline
\end{tabular}

\subsubsection{Dokumentasi}

Dokumentasi adalah mencari data mengenai hal-hal atau variabel yang berupa catatan, transkrip, buku, surat kabar, majalah, prasasti, notulen, rapat, lengger, agenda, dan sebagainya (Arikunto, 2002: 206). Penulis menggunakan metode ini untuk mengumpulkan data mengenai keadaan dan hasil produksi dengan mengambil dokumentasi yang berada di Home Industry Trio Desa Tegalwangi Kabupaten Tegal, baik berupa foto, data data penilaian karyawan dan data lain yang sangat diperlukan.

Penulis menggunakan metode ini juga untuk memperoleh data penunjang yang menguraikan secara global penilaian dari pimpinan Home Industry Trio terhadap sejauh mana tingkat produktivitas karyawannya yang berkaitan dengan kesenangan mereka dalam mendengarkan musik dangdut sebagai pengiring mereka bekerja.

Instrumen penilaian yang digunakan yaitu berupa borang seperti berikut:

Tabel 3.2

Borang Penilaian Tingkat Produktivitas Karyawan 


\begin{tabular}{|c|c|c|c|c|c|c|c|}
\hline \multirow{2}{*}{ No. } & \multirow{2}{*}{ Nama } & \multirow{2}{*}{ Bagian } & \multicolumn{4}{|c|}{ Aspek Penilaian } & $\begin{array}{c}\text { Rata } \\
\text { rata }\end{array}$ \\
\hline & & & Absensi & Disiplin & Target & Kualitas & \\
\hline 1 & Rohibun & Bubut & & & & & \\
\hline & & & & & & & \\
\hline & & & & & & & \\
\hline & & & & & & & \\
\hline & & & & & & & \\
\hline
\end{tabular}

\subsection{Validitas Dan Reliabilitas}

\subsubsection{Validitas}

Menurut Arikunto (2013: 211) validitas adalah suatu yang menunujukan tingkattingkat kevalidan atau kesahihan suatu instrumen. Suatu instrument yang valid atau sahih mempunyai validitas tinggi. Sebaliknya instrument yang kurang valid bebrarti memiliki validitas rendah.

Langkah yang digunakan untuk menguji validitas angket adalah dengan validitas eksternal, dengan mengkorelasikan antara tiap skor butir dengan skor totalnya yaitu menggunakan rumus korelasi product momen dari pearson, adapun rumusnya adalah sebagai berikut:

$$
r_{x y}=\frac{N \Sigma X Y-(\Sigma X)(\Sigma Y)}{\sqrt{\left\{N \Sigma X^{2}-(\Sigma X)^{2}\right\}\left\{N \Sigma Y^{2}-(\Sigma Y)^{2}\right\}}}
$$

Keterangan:

$\mathrm{r}_{\mathrm{xy}} \quad=$ koefisien antara variabel $\mathrm{X}$ dan $\mathrm{Y}$, dua variabel yang dikorelasikan

$\mathrm{N} \quad$ = Jumlah subyek 


$$
\begin{aligned}
& \Sigma X Y=\text { Jumlah perkalian } \mathrm{x} \text { dengan } \mathrm{y} \\
& \Sigma \mathrm{X}=\text { jumlah skor } \mathrm{x} \\
& \Sigma \mathrm{Y}=\text { jumlah skor } \mathrm{y} \\
& \Sigma \mathrm{X}^{2}=\text { jumlah skor } \mathrm{x} \text { kuadrat } \\
& \Sigma \mathrm{Y}^{2}=\text { jumlah skor } \mathrm{y} \text { kuadrat }
\end{aligned}
$$

Dengan menggunakan rumus korelasi Product Moment dari pearson di atas, dapat diperoleh nilai validitas instrument kesenangan mendengarkan musik dangdut. Berikut ini adalah tabel hasil uji validitas instrument kesenangan mendengarkan musik,

\begin{tabular}{|c|c|c|c|c|c|c|c|c|c|c|c|c|c|c|c|c|}
\hline & \multicolumn{16}{|c|}{ No. Soal } \\
\hline & 1 & 2 & 3 & 4 & 5 & 6 & 7 & 8 & 9 & 10 & 11 & 12 & 13 & 14 & 15 & 16 \\
\hline SX & 126 & 131 & 103 & 134 & 125 & 129 & 113 & 137 & 113 & 111 & 128 & 127 & 127 & 131 & 129 & 134 \\
\hline $\mathrm{SX}^{2}$ & 544 & 583 & 373 & 608 & 537 & 567 & 457 & 633 & 459 & 431 & 554 & 557 & 553 & 585 & 573 & 606 \\
\hline SXY & 8508 & 8812 & 6952 & 8987 & 8457 & 8681 & 7647 & 9171 & 7662 & 7538 & 8593 & 8547 & 8556 & 8839 & 8693 & 8989 \\
\hline $\mathrm{r}_{\mathrm{xy}}$ & 0.77 & 0.67 & 0.53 & 0.51 & 0.83 & 0.65 & 0.55 & 0.44 & 0.6 & 0.82 & 0.62 & 0.51 & 0.63 & 0.8 & 0.6 & 0.6 \\
\hline $\mathrm{r}_{\text {tabel }}$ & 0.36 & 0.36 & 0.36 & 0.36 & 0.36 & 0.36 & 0.36 & 0.36 & 0.36 & 0.36 & 0.36 & 0.36 & 0.36 & 0.36 & 0.36 & 0.36 \\
\hline Kriteria & Valid & Valid & Valid & Valid & Valid & Valid & Valid & Valid & Valid & Valid & Valid & Valid & Valid & Valid & Valid & Valid \\
\hline
\end{tabular}
yaitu:

Tabel 3.3

\section{Hasil uji validitas instrument kesenangan mendengarkan musik dangdut dari 30 responden}

pada nilai kepercayaan 5\% dengan $\mathrm{n}=30$ diperoleh $\mathrm{r}$ tabel 0,361. Dari tabel di atas menunjukan bahwa butir nomer $1,2,3,4,5,6,7,8,9,10,11,12,13,14,15$, dan 
16 dinyatakan valid karena $\mathrm{r}$ hitung (rxy) yang diperoleh oleh masing-masing butir soal $>$ dari $r$ tabel

\subsubsection{Reliabilitas}

Reliabilitas menunjuk pada satu pengertian bahwa suatu instrumen cukup dapat dipercaya untuk digunakan sebagai alat penumpul data karena instrument tersebut sudah baik. Instrumen yang baik tidak akan tendensius mengarahkan responden untuk memilih jawaban-jawaban tertentu. Instrumen yang sudah dapat dipercaya, yang reliabel akan menghasilkan data yang dapat dipercaya juga. Apabila datanya memang benar sesuai dengan kenyataanya, maka berapa kalipun diambil hasilnya akan tetap sama sesuai dengan konsepnya yaitu konsistensi gabungan butir. Reliabilitas menunjuk pada tingkat keterandalan sesuatu. Reliabel artinya dapat dipercaya, jadi dapat diandalkan. (Arikunto, 2013: 221).

Untuk mencari reabilitas pada penelitian ini mengunakan rumus Alpha karena instrumennya yang digunakan berbentuk angket. Rumus yang digunakan adalah sebagai berikut:

$$
r_{11}=\left(\frac{\mathbf{k}}{(k-1)}\right)\left(\frac{1-\Sigma \sigma_{b}^{2}}{\sigma t^{2}}\right)
$$

\section{Keterangan:}

$\mathbf{r}_{11}=$ reliabilitas instrument

$\mathrm{k} \quad$ = banyaknya butir pertanyaan atau banyaknya soal

$\Sigma \sigma b^{2}=$ jumlah varian butir soal 
$\sigma t^{2}=$ varian total

Dengan menggunakan rumus alpha di atas, dapat diperoleh hasil sebagai berikut:

$$
\begin{aligned}
& \sigma t^{2}=52,173 \\
& \Sigma \sigma b^{2}=8,56 \\
& r_{11}=0,892
\end{aligned}
$$

pada nilai kepercayaan 5\% dengan $\mathrm{n}=30$ diperoleh $\mathrm{r}$ table $=0,361$. Karena $\mathrm{r} 11$ > r table, maka dapat disimpulkan bahwa instrument tersebut reliabel.

\subsection{Teknik Analisis Data}

\subsubsection{Analisis Deskriptif Presentase}

Analisis deskriptif prosentase dalam penelitian ini digunakan untuk mendeskripsikan masing-masing variabel yaitu tingkat kesenangan mendengarkan musik dan tingkat produktivitas karyawan Home Industry Trio apakah termasuk dalam kategori tinggi, sedang, rendah dan cukup secara keseluruhan maupun tiap karyawan. Dalam penelitian ini data yang diperoleh dari angket berupa angka-angka, maka penulis menggunakan analisis statistic. Teknik yang dipakai untuk memperoleh data penelitian adalah statistic deskriptif dengan analisis deskriptif presentase. Rumus yang digunakan untuk mencari persentase adalah sebagai berikut:

$$
P=\frac{F}{N} \times 100 \%
$$

Keterangan:

P: Angka Persentae 
F: Frekuensi yang sedang dicari persentasenya

$\mathrm{N}$ : Jumlah responden

(Sudijono, 2004: 43)

Setelah melkukan perhitungan skor kemudian dilakukan representasi terhadap prosentase skor tersebut dengan cara:

Menetapkan persentase tertinggi: $5 / 5 \times 100 \%=100 \%$

Menetapkan persentase terendah: $1 / 5 \times 100 \%=20 \%$

Menetapkan rentangan persentase : $100 \%-20 \%=80 \%$

Menetapkan kelas interval persentase : $80 \% / 5=16 \%$

Maka kategori untuk masing-masing variabel adalah sebagai berikut:

$84 \%-100 \%=$ Sangat tinggi

$68 \%-83 \%=$ Tinggi

$52 \%-67 \%=$ Cukup tinggi

$37 \%-51 \%=$ Rendah

$20 \%-36 \%=$ Sangat rendah

\subsubsection{Analisis Korelasi}

Metode penelitian yang digunakan pada penelitian ini adalah metode kuantitatif, sehinggga setelah data terkumpul, penulis mengolah dan menganalisa secara deskriptif dengan teknik prosentase untuk mengetahui frekuensi gejala yang muncul dengan mengubah data tersebut kebentuk angka-angka. Sedangkan untuk mengetahui hubungan antara variabel kesenangan hubungan mendengarkan musik dangdut dengan variabel tingkat produktivitas karyawan digunakan teknik statistik regresi dan korelasi 
linier sederhana dengan rumus korelasi product moment yang dibantu dengan kompetensi program SPSS (Statistical productand service Solution) for Windows Release versi 16.0. Teknik analisis data menggunakan tahapan-tahapan analisis sebagai berikut:

\subsubsection{Uji Prasyarat Analisis}

Sebelum dilakukan analisis data tersebut, maka dilakukan uji asumsi untuk menguji keabsahan data terebut, yang meliputi: 1). Uji Normalitas dan Uji Linieritas. Uji normalitas digunakan untuk mengetahui apakah data yang diperoleh berdistribusi secara normal atau tidak. Uji normalitas ini dilakukan dengan menggunakan teknik One sample kolomogrov-snirnov dengan bantuan SPSS versi 16.0 for windows. Data dikatakan distribusi secara normal jika harga $\mathrm{p}>0,05$ dan jika $\mathrm{p}<0,05$ maka data dikatakan distribusi secara tidak normal. Uji linieritas digunakan untuk mengetahui apakah data variabel X (kesenangan mendengarkan musik) dan variabel Y (tingkat produktivitas) memiliki hubungan linier atau tidak. Uji linieritas dilakukan dengan menggunakan uji $F$ (Anova) dengan bantuan SPSS versi 16.0 for windows. Data dikatakan linier apabila nilai $\mathrm{p}<0,05$ dan jika $\mathrm{p}>0,05$ maka data dikatakan tidak linier.

\subsubsection{Analisis Uji Hipotesis}

Hipotesis adalah "suatu jawaban yang bersifat sementara terhadap permasalahan penelitian, sampai terbukti melalui data yang terkumpul” ( Arikunto, 2013: 110). Dia akan ditolak jika salah atau palsu, dan akan diterima jika fakta-fakta membebarrkan". Hipotesis mempunyai sifat sementara, artinya ia aka diubah dengan hipotesis lain yang lebih tepat, dan hipotesa sebagai rumusan proposisi akan diuji kebenaranya melalui 
penelitian untuk dapat diterima atau ditolak. Dan hipotesis ini mengarahkan penelitian akan data yang dibutuhkan dalam penelitian tentang jawaban terhadap rumusan tujuan penelitian.

\subsubsection{Uji Hipotesis 1}

Untuk mengetahui adakah korelasi antara kesenangan mendengarkan musik dangdut dengan tingkat produktivitas karyawan menggunakan teknik correlations bantuan SPSS versi 16.0 for windows, apabila nila rxy > r tabel 0,361 dari N=30 maka dapat dikatakan terdapat hubungan yang signifikan antara kesenangan mendengarkan musik dangdut dengan tingkat produktivitas karyawan Home Industry Trio.

Untuk mengetahui seberapa besar kontribusi kesenangan mendengarkan musik dangdut terhadap tingkat produktivitas karyawan, dapat diketahui dengan menggunakan koefisien determinasi ganda dengan model summary SPSS versi 16.0 for windows.

\subsubsection{Uji Hipotesis 2}

Untuk mengetahui ada atau tidaknya pengaruh kesenangan mendengarkan musik dangdut terhadap tingkat produktifitas karyawan, dapat digunakan analisis regresi dengan menggunakan coefficient SPSS versi 16.0 for windows.

\section{BAB 4}

HASIL PENELITIAN DAN PEMBAHASAN 


\subsection{Home Industry Trio Desa Tegalwangi Kabupaten Tegal}

Kabupaten Tegal adalah salah satu Kabupaten yang berada di Provinsi Jawa Tengah yang beribukota di Kota Slawi. Mayoritas penduduknya yaitu memperoleh penghasilan dari usaha baik itu merantau maupun di daerah sendiri. Bentuk dari usahanya beragam, diantaranya yaitu: berdagang, industri rumahan pandai besi/logam, warteg, tekstil, batik, tembikar, pengolahan makanan, dan lain sebagainya. Namun yang bisa dibilang paling menonjol yaitu industri rumahan pandai besi/logam yang sudah terkenal dimana mana. Sampai dengan saat ini di Kabupaten Tegal banyak sekali berkembang industri rumahan pandai besi/logam dikarenakan usaha ini menghasilkan begitu banyak keuntungan. Salah satunya ialah Home Industri Trio.

Home Industry Trio beralamatkan di Jl. Mawar Rt.12 Rw.04 Desa Tegalwangi, Kecamatan Talang, Kabupaten Tegal adalah salah satu dari sekian banyak Home Industry yang berkembang di Kabupaten Tegal yang sudah berdiri sejak tahun 1978. Pendiri Home Industry ini yaitu Bapak Sarkadi yang sudah meninggal sejak tahun 1991, kemudian diteruskan dan dikelola kembali oleh ketiga orang putranya yang kemudian memunculkan nama Trio sebagai nama Home Industry tersebut dan masih berdiri sampai sekarang ini sebagai penghasil bos becak dan produk produk yang lain. Jumlah keseluruhan karyawan di Home Industry Trio yaitu 53 orang laki laki yang terdiri dari berbagai macam usia dengan keterampilan dan karakter yang berbeda beda. Mesin mesin yang digunakan seperti pada umumnya yaitu: mesin bubut, mesin las asitilin, mesin gerinda, mesin poles, mesin lebur, mesin bor, dan lain lain. 
Hampir semua Home Industry di Kabupaten Tegal menyediakan sebuah radio tape sebagai media pengiring musik para karyawan disaat sedang bekerja. Salah satunya yaitu Home Industry Trio, berikut ini akan penulis uraikan hal yang menjadi pertimbangan mengapa memilih Home Industry Trio sebagai lokasi penelitian, yaitu: 1. Desa Tegalwangi merupakan salah satu Desa yang masuk kedalam kawasan sentra Home Industry di Kabupaten Tegal. 2. Lokasi berada di dekat sekitar rumah peneliti sehingga mengurangi biaya akomodasi dan lain lain yang bisa memberatkan.

\subsection{Hasil Penelitian}

\subsubsection{Deskripsi Data}

Dalam penelitian ini akan dibahas menganai deskripsi data masing-masing variabel penelitian dan pengaruh kesenangan mendengarkan musik dangdut dengan tingkat produktivitas karyawan Home Industry Trio Desa Tegalwangi Kabuaten Tegal.

\subsubsection{Variabel Tingkat Produktivitas karyawan (Y)}

Data nilai produktivitas karyawan Home Industry Trio diperoleh dari borang penilaian kinerja yang di isi langsung oleh pemimpin Home Industry Trio yang bertanggung jawab atas baik atau buruknya kinerja karyawannya sendiri. Kriteria penilaian produktivitas dapat dilihiat dari 4 indikator yaitu absensi, disiplin, target produksi, dan kualitas produksi.

Setelah dilakukan penilaian terhadap karyawan, selanjutnya yaitu pengambilan nilai sejumlah sampel yang sudah ditentukan. Dimana pada penelitian ini sampel yang digunakan yaitu 30 karyawan. Sehingga diperoleh tabel distribusi tingkat produktivitas sebagai berikut: 
Tabel 4.1

Rata rata penilaian produktivitas karyawan Home Industry Trio

\begin{tabular}{|c|c|c|c|}
\hline Interval persen & Kriteria & Frekuensi & Persentasi \\
\hline $84 \%-100 \%$ & Sangat baik & 2 & $6,7 \%$ \\
\hline $68 \%-83 \%$ & Baik & 28 & $93,3 \%$ \\
\hline $52 \%-67 \%$ & Cukup & 0 & 0 \\
\hline $37 \%-51 \%$ & Tidak baik & 0 & 0 \\
\hline $20 \%-36 \%$ & Sangat tidak baik & 0 & 0 \\
\hline \multicolumn{2}{|c|}{ Jumlah responden } & 30 & $100 \%$ \\
\hline skor rata rata yang diperoleh & \multicolumn{2}{|c|}{2237,5} \\
\hline Jumlah skor rata rata ideal & \multicolumn{2}{|c|}{$74,6 \%$} \\
\hline \multicolumn{2}{|c|}{ Rata-rata } & \multicolumn{2}{c}{} \\
\hline
\end{tabular}

Berdasarkan tabel di atas dapat diketahui dari 30 sampel karyawan Home Industry Trio diperoleh gambaran interval tingkat produktivitas sebagai berikut:

Sebanyak 2 karyawan $(6,7 \%)$ memiliki tingkat produktivitas termasuk dalam kriteria sangat baik, 28 karyawan $(93,3 \%)$ memiliki tingkat produktivitas termasuk dalam kriteria baik, 0 karyawan $(0 \%)$ memiliki tingkat produktivitas termasuk dalam kriteria cukup, 0 karyawan $(0 \%)$ memiliki tingkat produktivitas termasuk dalam kriteria tidak baik, dan 0 karyawan $(0 \%)$ memiliki tingkat produktivitas termasuk dalam kriteria sangat tidak baik. Secara klasikal persentasi tingkat produktivitas karyawan Home Industry Trio sebesar 74,6\%, dan termasuk kedalam kriteria baik.

Untuk lebih jelasnya dapat juga digambarkan dalam bentuk diagram batang distribusi seperti berikut:

\section{Diagram 4.1}

\section{Distribusi Frekuensi Produktivitas Karyawan}




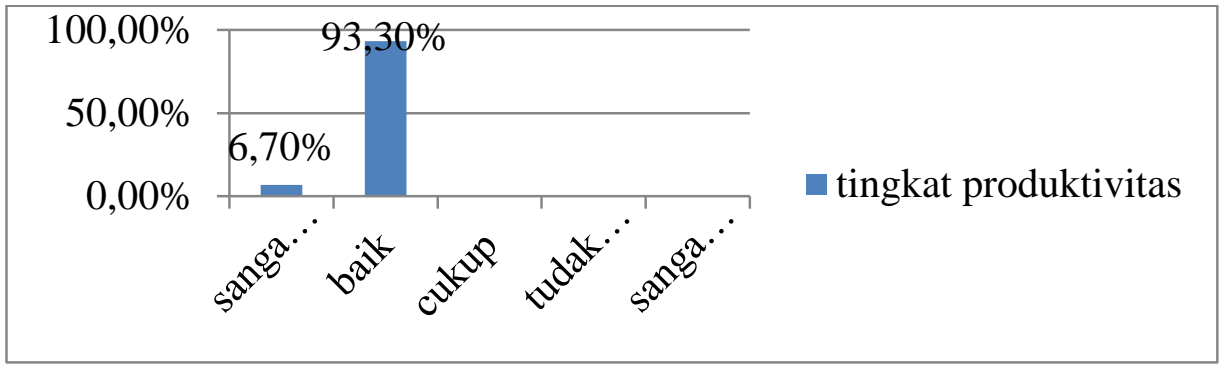

Untuk lebih detailnya mengenai variabel tingkat produktivias karyawan Home Industry Trio dapat dilihat dari deskripsi tiap-tiap indikator tingkat produktivitas seperti berikut:

\section{Tingkat absensi karyawan Home Industry Trio}

Berdasarkan hasil observasi di Home Industry Trio, diperoleh gambaran tentang tingkat absensi karyawan sebagai berikut:

Tabel 4.2

Tingkat absensi karyawan Home Industry Trio

\begin{tabular}{|c|c|c|c|}
\hline $\begin{array}{c}\text { Interval } \\
\text { persen }\end{array}$ & Kriteria & Frekuensi & Persentasi \\
\hline $84 \%-100 \%$ & Sangat baik & 2 & $6,7 \%$ \\
\hline $68 \%-83 \%$ & Baik & 28 & $93,3 \%$ \\
\hline $52 \%-67 \%$ & Cukup & 0 & 0 \\
\hline $37 \%-51 \%$ & Tidak baik & 0 & 0 \\
\hline $20 \%-36 \%$ & Sangat tidak baik & 0 & 0 \\
\hline \multicolumn{2}{|c|}{ Jumlah responden } & 30 & $100 \%$ \\
\hline \multicolumn{3}{|c|}{3250} \\
\hline \multicolumn{3}{|c|}{$75 \%$} \\
\hline \multicolumn{2}{|c|}{ Jumlah skor yang diperoleh } & \multicolumn{3}{|c|}{} \\
\hline
\end{tabular}

Berdasarkan tabel di atas dapat diketahui dari 30 sampel karyawan Home

Industry Trio diperoleh gambaran interval tingkat absensi sebagai berikut:

Sebanyak 2 karyawan $(6,7 \%)$ memiliki tingkat absensi termasuk dalam kriteria sangat baik, 28 karyawan $(93,3 \%)$ memiliki tingkat absensi termasuk dalam kriteria 
baik, 0 karyawan $(0 \%)$ memiliki tingkat absensi termasuk dalam kriteria cukup, 0 karyawan $(0 \%)$ memiliki tingkat absensi termasuk dalam kriteria tidak baik, dan 0 karyawan (0\%) memiliki tingkat absensi termasuk dalam kriteria sangat tidak baik. Secara klasikal persentasi tingka absensi karyawan Home Industry Trio sebesar $75 \%$, dan termasuk kedalam kriteria baik.

Untuk lebih jelasnya dapat juga digambarkan dalam bentuk diagram batang distribusi seperti berikut:

Diagram 4.2

\section{Distribusi Frekuensi Tingkat Absensi}

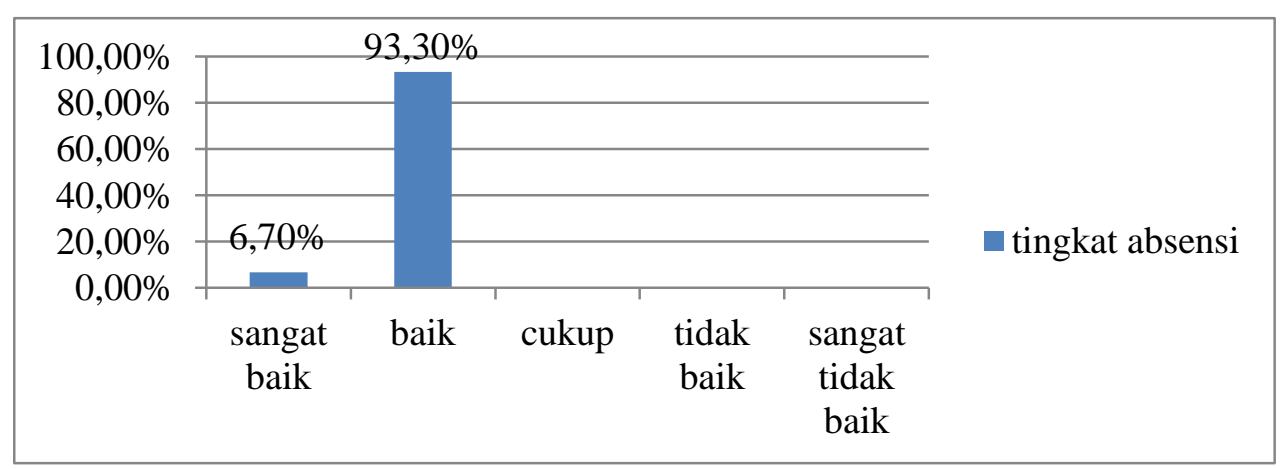

2. Tingkat disiplin karyawan Home Industry Trio

Berdasarkan hasil observasi di Home Industry Trio, diperoleh gambaran tentang tingkat disiplin karyawan sebagai berikut:

Tabel 4.3

Tingkat disiplin karyawan Home Industry Trio

\begin{tabular}{|c|c|c|c|}
\hline $\begin{array}{c}\text { Interval } \\
\text { persen }\end{array}$ & Kriteria & Frekuensi & Persentasi \\
\hline $84 \%-100 \%$ & Sangat baik & 2 & $6,7 \%$ \\
\hline $68 \%-83 \%$ & Baik & 28 & $93,3 \%$ \\
\hline
\end{tabular}




\begin{tabular}{|c|c|c|c|}
$52 \%-67 \%$ & Cukup & 0 & 0 \\
\hline $37 \%-51 \%$ & Tidak baik & 0 & 0 \\
\hline $20 \%-36 \%$ & Sangat tidak baik & 0 & 0 \\
\hline \multicolumn{2}{|c|}{ Jumlah responden } & 30 & $100 \%$ \\
\hline Jumlah skor yang diperoleh & \multicolumn{2}{|c|}{2270} \\
\hline Jumlah skor ideal & \multicolumn{3}{|c|}{3000} \\
\hline Rata-rata & \multicolumn{3}{|c|}{$75,6 \%$} \\
\hline
\end{tabular}

Berdasarkan tabel di atas dapat diketahui dari 30 sampel karyawan Home Industry Trio diperoleh gambaran interval tingkat disiplin sebagai berikut:

Sebanyak 2 karyawan $(6,7 \%)$ memiliki tingkat disiplin termasuk dalam kriteria sangat baik, 28 karyawan $(93,3 \%)$ memiliki tingkat disiplin termasuk dalam kriteria baik, 0 karyawan $(0 \%)$ memiliki tingkat disiplin termasuk dalam kriteria cukup, 0 karyawan $(0 \%)$ memiliki tingkat disiplin termasuk dalam kriteria tidak baik, dan 0 karyawan (0\%) memiliki tingkat disiplin termasuk dalam kriteria sangat tidak baik. Secara klasikal persentasi tingka disiplin karyawan Home Industry Trio sebesar 75,6\%, dan termasuk kedalam kriteria baik.

Untuk lebih jelasnya dapat juga digambarkan dalam bentuk diagram batang distribusi seperti berikut:

Diagram 4.3

Distribusi frekuensi tingkat disiplin 


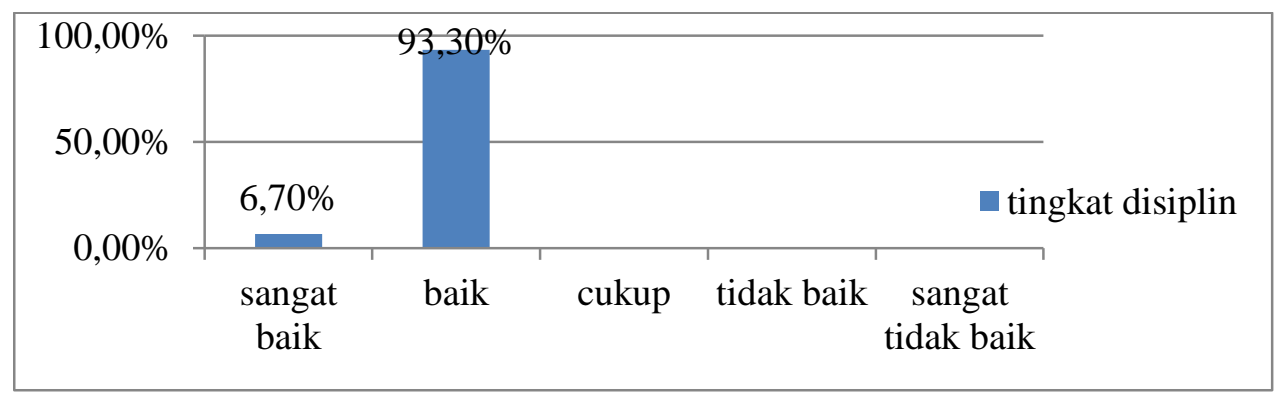

3. Tingkat pencapaian target karyawan Home Industry Trio

Berdasarkan hasil observasi di Home Industry Trio, diperoleh gambaran tentang tingkat pencapaian target karyawan sebagai berikut:

Tabel 4.4

Tingkat pencapaian target karyawan Home Industry Trio

\begin{tabular}{|c|c|c|c|}
\hline $\begin{array}{c}\text { Interval } \\
\text { persen }\end{array}$ & Kriteria & Frekuensi & Persentasi \\
\hline $84 \%-100 \%$ & Sangat baik & 3 & $10 \%$ \\
\hline $68 \%-83 \%$ & Baik & 27 & $90 \%$ \\
\hline $52 \%-67 \%$ & Cukup & 0 & 0 \\
\hline $37 \%-51 \%$ & Tidak baik & 0 & 0 \\
\hline $20 \%-36 \%$ & Sangat tidak baik & 0 & 0 \\
\hline \multicolumn{2}{|c|}{ Jumlah responden } & 30 & $100 \%$ \\
\hline \multicolumn{2}{|c|}{ Jumlah skor yang diperoleh } & 3000 \\
\hline \multicolumn{2}{|c|}{ Jumlah skor ideal } & \multicolumn{2}{|c|}{} \\
\hline \multicolumn{3}{|c|}{ Rata-rata }
\end{tabular}

Berdasarkan tabel di atas dapat diketahui dari 30 sampel karyawan Home Industry Trio diperoleh gambaran interval tingkat pencapaian target sebagai berikut:

Sebanyak 3 karyawan (10\%) memiliki tingkat pencapaian target termasuk dalam kriteria sangat baik, 27 karyawan (90\%) memiliki tingkat pencapaian target termasuk dalam kriteria baik, 0 karyawan $(0 \%)$ memiliki tingkat pencapaian target termasuk 
dalam kriteria cukup, 0 karyawan $(0 \%)$ memiliki tingkat pencapaian target termasuk dalam kriteria tidak baik, dan 0 karyawan $(0 \%)$ memiliki tingkat pencapaian target termasuk dalam kriteria sangat tidak baik. Secara klasikal persentasi tingkat pencapaian target karyawan Home Industry Trio sebesar 74\%, dan termasuk kedalam kriteria baik.

Untuk lebih jelasnya dapat juga digambarkan dalam bentuk diagram batang distribusi seperti berikut:

\section{Diagram 4.4}

Distribusi frekuensi tingkat pencapaian target

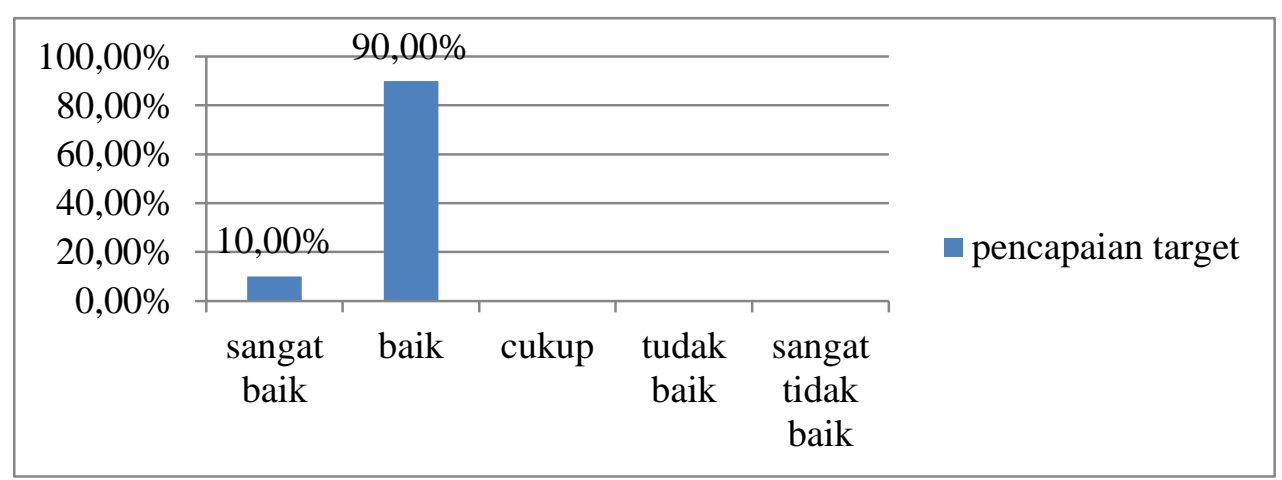

4. Tingkat kualitas produksi karyawan Home Industry Trio

Berdasarkan hasil observasi di Home Industry Trio, diperoleh gambaran tentang tingkat kualitas produksi karyawan sebagai berikut:

Tabel 4.5

Tingkat kualitas produksi karyawan Home Industry Trio

\begin{tabular}{|c|c|c|c|}
\hline $\begin{array}{c}\text { Interval } \\
\text { persen }\end{array}$ & Kriteria & Frekuensi & Persentasi \\
\hline $84 \%-100 \%$ & Sangat baik & 0 & $0 \%$ \\
\hline
\end{tabular}




\begin{tabular}{|c|c|c|c|}
\hline $68 \%-83 \%$ & Baik & 30 & $100 \%$ \\
\hline $52 \%-67 \%$ & Cukup & 0 & 0 \\
\hline $37 \%-51 \%$ & Tidak baik & 0 & 0 \\
\hline $20 \%-36 \%$ & Sangat tidak baik & 0 & 0 \\
\hline Jumlah responden & 30 & $100 \%$ \\
\hline Jumlah skor yang diperoleh & \multicolumn{2}{|c|}{2210} \\
\hline Jumlah skor ideal & \multicolumn{2}{|c|}{3000} \\
\hline Rata-rata & \multicolumn{2}{|c|}{$73,6 \%$} \\
\hline
\end{tabular}

Berdasarkan tabel di atas dapat diketahui dari 30 sampel karyawan Home Industry Trio diperoleh gambaran interval tingkat kualitas produksi sebagai berikut:

Tidak ada karyawan yang memiliki tingkat kualitas produksi termasuk dalam kriteria sangat baik, 30 karyawan (100\%) memiliki tingkat kualitas produksi termasuk dalam kriteria baik, 0 karyawan $(0 \%)$ memiliki tingkat kualitas produksi termasuk dalam kriteria cukup, 0 karyawan (0\%) memiliki tingkat kualitas produksi termasuk dalam kriteria tidak baik, dan 0 karyawan $(0 \%)$ memiliki tingkat kualitas produksi termasuk dalam kriteria sangat tidak baik. Secara klasikal persentasi tingka kualitas produksi karyawan Home Industry Trio sebesar 73,6\%, dan termasuk kedalam kriteria baik.

Untuk lebih jelasnya dapat juga digambarkan dalam bentuk diagram batang distribusi seperti berikut:

\section{Diagram 4.5}

\section{Distribusi frekuensi tingkat kualitas produksi}




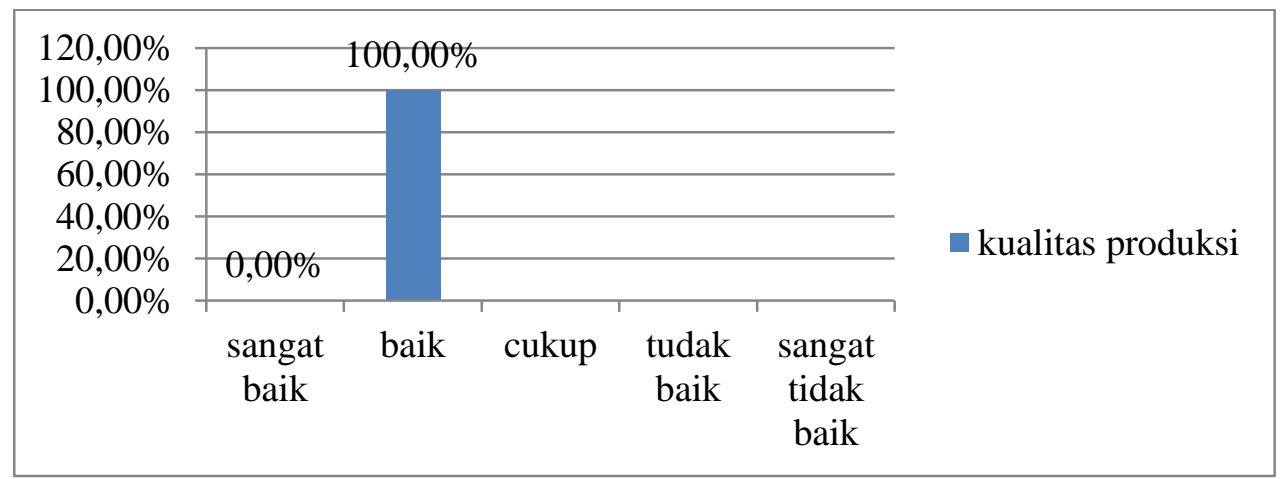

\subsubsection{Variabel Tigkat Kesenangan Mendengarkan Musik Dangdut (X)}

Setelah dilakukan pengujian instrumen terhadap 30 responden, maka dilanjutkan dengan pengumpulan data dan pengambilan nilai yang di dapat dari data tingkat kesenangan mendengarkan musik dangdut dari nilai angket atau kuisioner yang telah diisi oleh 30 karyawan Home Industry Trio yang menjadi sampel pada penilitian ini.

kriteria penilaian pada angket ini dilihat dari 4 indikator yaitu kegemaran, kepuasan hati, kenikmatan, dan motivasi yang didalamnya terbagi menjadi 16 item pertanyaan mengunakan skala likert yang meliputi: a).sangat setuju; b).setuju; c).cukup setuju; d).kurang setuju; dan e).sangat tidak setuju. Angket ini diisi langsung oleh para karyawan yang terpilih menjadi sampel dan disebar langsung oleh peneliti sejumlah 30 angket.

Dari hasil nilai angket kesenangan mendengarkan musik dangdut di atas, maka diperoleh distribusi tingkat kesenangan mendengarkan musik dangdut sebagaimana tertera seperti pada tabel di bawah ini.

Tabel 4.6 


\section{Rata rata penilaian kesenangan mendengarkan musik dangdut}

\section{karyawan Home Industry Trio}

\begin{tabular}{|c|c|c|c|}
\hline $\begin{array}{c}\text { Interval } \\
\text { persen }\end{array}$ & Kriteria & Frekuensi & Persentasi \\
\hline $86 \%-100 \%$ & Sangat baik & 13 & $43,3 \%$ \\
\hline $66 \%-85 \%$ & Baik & 15 & $50 \%$ \\
\hline $46 \%-65 \%$ & Cukup & 2 & $6,7 \%$ \\
\hline $26 \%-45 \%$ & Tidak baik & 0 & 0 \\
\hline $20 \%-35 \%$ & Sangat tidak baik & 0 & 0 \\
\hline \multicolumn{2}{|c|}{ Jumlah responden } & 30 & $100 \%$ \\
\hline \multicolumn{2}{|c|}{ Jumlah rata rata yang diperoleh } & \multicolumn{2}{|c|}{1998} \\
\hline \multicolumn{2}{|c|}{ Jumlah skor rata rata ideal } & \multicolumn{2}{|c|}{2400} \\
\hline \multicolumn{2}{|c|}{ Rata-rata } & \multicolumn{2}{|c|}{$83,25 \%$} \\
\hline
\end{tabular}

Berdasarkan tabel di atas dapat diketahui dari 30 sampel karyawan Home Industry Trio diperoleh gambaran interval kesenangan mendengarkan musik dangdut sebagai berikut:

Sebanyak 13 karyawan $(43,3 \%)$ memiliki tingkat kesenangan mendengarkan musik dangdut termasuk dalam kriteria sangat baik, 15 karyawan (50\%) memiliki tingkat kesenangan mendengarkan musik dangdut termasuk dalam kriteria baik, 2 karyawan $(6,7 \%)$ memiliki tingkat kesenangan mendengarkan musik dangdut termasuk dalam kriteria cukup, 0 karyawan $(0 \%)$ memiliki tingkat kesenangan mendengarkan musik dangdut termasuk dalam kriteria tidak baik, dan 0 karyawan (0\%) memiliki tingkat kesenangan mendengarkan musik dangdut termasuk dalam kriteria sangat tidak baik. Secara klasikal persentasi tingkat kesenangan mendengarkan musik dangdut karyawan Home Industry Trio sebesar 83,25\%, dan termasuk kedalam kriteria baik. 
Untuk lebih jelasnya dapat juga digambarkan dalam bentuk diagram batang distribusi seperti berikut:

\section{Diagram 4.6}

\section{Distribusi frekuensi rata rata tingkat kesenangan mendengarka} musik dangdut

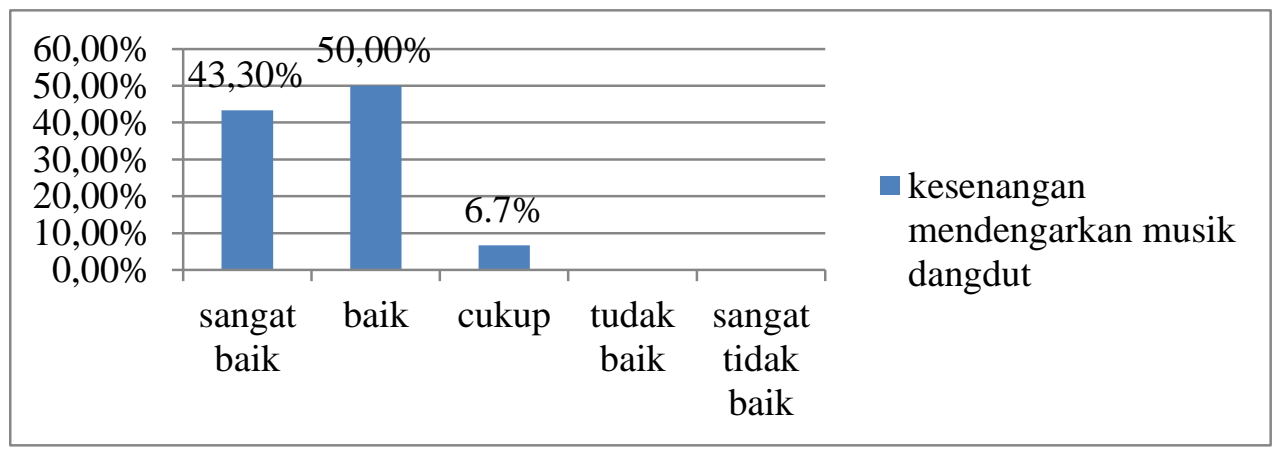

Untuk lebih detailnya mengenai variabel tingkat kesenangan mendengarkan musik dangdut karyawan Home Industry Trio dapat dilihat dari deskripsi tiap tiap indikator tingkat produktivitas seperti berikut:

1. Tingkat kegemaran musik dangdut karyawan Home Industry Trio

Berdasarkan hasil observasi di Home Industry Trio, diperoleh gambaran tentang tingkat absensi karyawan sebagai berikut:

Tabel 4.7

Tingkat kegemaran musik dangdut karyawan Home Industry Trio

\begin{tabular}{|c|c|c|c|}
\hline $\begin{array}{c}\text { Interval } \\
\text { persen }\end{array}$ & Kriteria & Frekuensi & Persentasi \\
\hline $86 \%-100 \%$ & Sangat baik & 10 & $33,3 \%$ \\
\hline $66 \%-85 \%$ & Baik & 17 & $56,7 \%$ \\
\hline
\end{tabular}




\begin{tabular}{|c|c|c|c|}
\hline $46 \%-65 \%$ & Cukup & 3 & $10 \%$ \\
\hline $26 \%-45 \%$ & Tidak baik & 0 & 0 \\
\hline $20 \%-35 \%$ & Sangat tidak baik & 0 & 0 \\
\hline \multicolumn{2}{|c|}{ Jumlah responden } & 30 & $100 \%$ \\
\hline \multicolumn{2}{|c|}{ Jumlah rata-rata skor } & \multicolumn{3}{|c|}{496} \\
\hline Jumlah skor rata rata ideal & \multicolumn{3}{|c|}{600} \\
\hline Rata-rata & \multicolumn{2}{|c|}{$82,6 \%$} \\
\hline
\end{tabular}

Berdasarkan tabel di atas dapat diketahui dari 30 sampel karyawan Home Industry Trio diperoleh gambaran interval kegemaran mendengarkan musik dangdut sebagai berikut:

Sebanyak 10 karyawan $(33,3 \%)$ memiliki tingkat kegemaran mendengar musik dangdut termasuk dalam kriteria sangat baik, 17 karyawan (56,7\%) memiliki tingkat kegemaran mendengar musik dangdut termasuk dalam kriteria baik, 3 karyawan (10\%) memiliki tingkat mendengar musik dangdut termasuk dalam kriteria cukup, 0 karyawan (0\%) memiliki tingkat kegemaran mendengar musik dangdut termasuk dalam kriteria tidak baik, dan 0 karyawan $(0 \%)$ memiliki tingkat kegemaran mendengar musik dangdut termasuk dalam kriteria sangat tidak baik. Secara klasikal persentasi tingkat kegemaran mendengar musik dangdut karyawan Home Industry Trio sebesar 82,6\%, dan termasuk kedalam kriteria baik.

Untuk lebih jelasnya dapat juga digambarkan dalam bentuk diagram batang distribusi seperti berikut:

\section{Diagram 4.7}

\section{Distribusi frekuensi kegemaran mendengar musik dangdut}




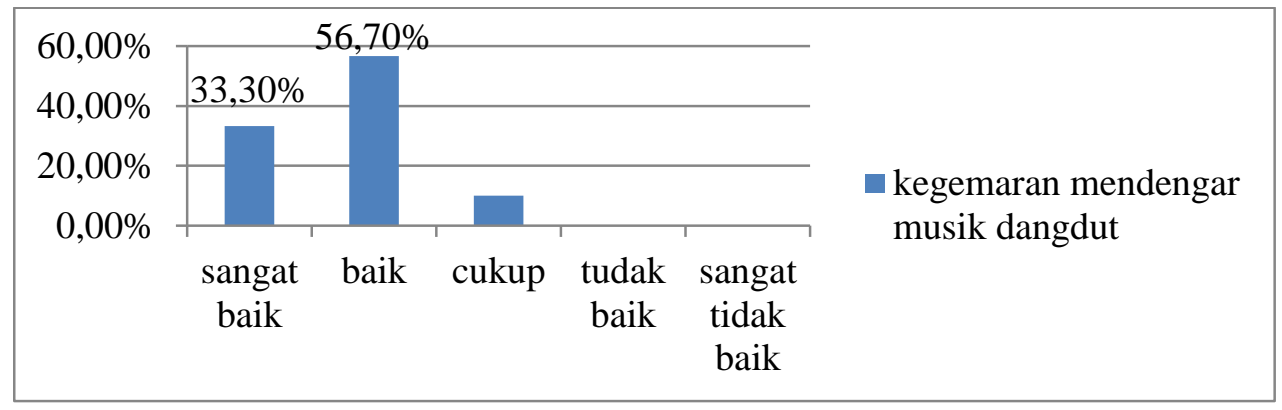

2. Tingkat kepuasan hati mendengar musik dangdut Home Industry Trio

Berdasarkan hasil observasi di Home Industry Trio, diperoleh gambaran tentang tingkat kepuasan hati mendengar musik dangdut karyawan sebagai berikut:

Tabel 4.8

Tingkat kepuasan hati mendengar musik dangdut karyawan

Home Industry Trio

\begin{tabular}{|c|c|c|c|}
\hline $\begin{array}{c}\text { Interval } \\
\text { persen }\end{array}$ & Kriteria & Frekuensi & Persentasi \\
\hline $86 \%-100 \%$ & Sangat baik & 8 & $26,7 \%$ \\
\hline $66 \%-85 \%$ & Baik & 19 & $63,3 \%$ \\
\hline $46 \%-65 \%$ & Cukup & 3 & $10 \%$ \\
\hline $26 \%-45 \%$ & Tidak baik & 0 & 0 \\
\hline $20 \%-35 \%$ & Sangat tidak baik & 0 & 0 \\
\hline \multicolumn{2}{|c|}{ Jumlah responden } & 30 & $100 \%$ \\
\hline \multicolumn{3}{|c|}{ Jumlah rata-rata skor } & 600 \\
\hline Jumlah skor rata rata ideal & \multicolumn{3}{|c|}{$84 \%$} \\
\hline
\end{tabular}

Berdasarkan tabel di atas dapat diketahui dari 30 sampel karyawan Home

Industry Trio diperoleh gambaran interval tingkat kepuasan hati mendengar musik dangdut sebagai berikut:

Sebanyak 8 karyawan $(26,7 \%)$ memiliki tingkat kepuasan hati mendengar musik dangdut termasuk dalam kriteria sangat baik, 19 karyawan (63,3\%) memiliki tingkat 
kepuasan hati mendengar musik dangdut termasuk dalam kriteria baik, 3 karyawan (10\%) memiliki tingkat kepuasan hati mendengar musik dangdut termasuk dalam kriteria cukup, 0 karyawan $(0 \%)$ memiliki tingkat kepuasan hati mendengar musik dangdut termasuk dalam kriteria tidak baik, dan 0 karyawan $(0 \%)$ memiliki tingkat kepuasan hati mendengar musik dangdut termasuk dalam kriteria sangat tidak baik. Secara klasikal persentasi tingkat kepuasan hati mendengar musi dangdut karyawan Home Industry Trio sebesar 84\%, dan termasuk kedalam kriteria baik.

Untuk lebih jelasnya dapat juga digambarkan dalam bentuk diagram batang distribusi seperti berikut:

\section{Diagram 4.8}

Distribusi frekuensi kepuasan hati mendengarkan musik dangdut

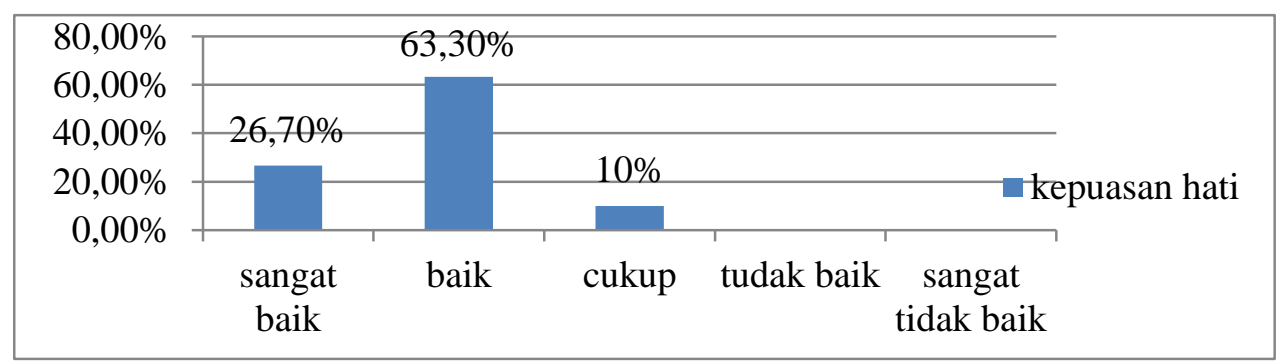

3. Tingkat kenikmatan mendengar musik dangdut karyawan Home Industry Trio

Berdasarkan hasil observasi di Home Industry Trio, diperoleh gambaran tentang tingkat kenikmatan mendengar musik dangdut karyawan sebagai berikut:

Tabel 4.9

Tingkat kenikmatan mendengar musik dangdut karyawan Home Industry Trio 


\begin{tabular}{|c|c|c|c|}
\hline $\begin{array}{c}\text { Interval } \\
\text { persen }\end{array}$ & Kriteria & Frekuensi & Persentasi \\
\hline $86 \%-100 \%$ & Sangat baik & 9 & $30 \%$ \\
\hline $66 \%-85 \%$ & Baik & 16 & $53,3 \%$ \\
\hline $46 \%-65 \%$ & Cukup & 5 & $16,7 \%$ \\
\hline $26 \%-45 \%$ & Tidak baik & 0 & 0 \\
\hline $20 \%-35 \%$ & Sangat tidak baik & 0 & 0 \\
\hline Jumlah responden & 30 & $100 \%$ \\
\hline \multicolumn{3}{|c|}{479} \\
\hline Jumlah rata-rata skor & \multicolumn{2}{|c|}{$79,8 \%$} \\
\hline
\end{tabular}

Berdasarkan tabel di atas dapat diketahui dari 30 sampel karyawan Home Industry Trio diperoleh gambaran interval tingkat kenikmatan mendengar musik dangdut karyawan sebagai berikut:

Sebanyak 9 karyawan (30\%) memiliki tingkat kenikmatan mendengar musik dangdut termasuk dalam kriteria sangat baik, 16 karyawan $(53,3 \%)$ memiliki tingkat kenikmatan mendengar musik dangdut termasuk dalam kriteria baik, 5 karyawan $(16,7 \%)$ memiliki tingkat kenikmatan mendengar musik dangdut termasuk dalam kriteria cukup, 0 karyawan $(0 \%)$ memiliki tingkat kenikmatan mendengar musik dangdut termasuk dalam kriteria tidak baik, dan 0 karyawan $(0 \%)$ memiliki tingkat kenikmatan mendengar musik dangdut termasuk dalam kriteria sangat tidak baik. Secara klasikal persentasi tingkat kenikmatan mendengar musik dangdut karyawan Home Industry Trio sebesar 79,8\%, dan termasuk kedalam kriteria baik.

Untuk lebih jelasnya dapat juga digambarkan dalam bentuk diagram batang distribusi seperti berikut:

\section{Diagram 4.9}




\section{Distribusi frekuensi tingkat kenikmatan mendengar musik dangdut}

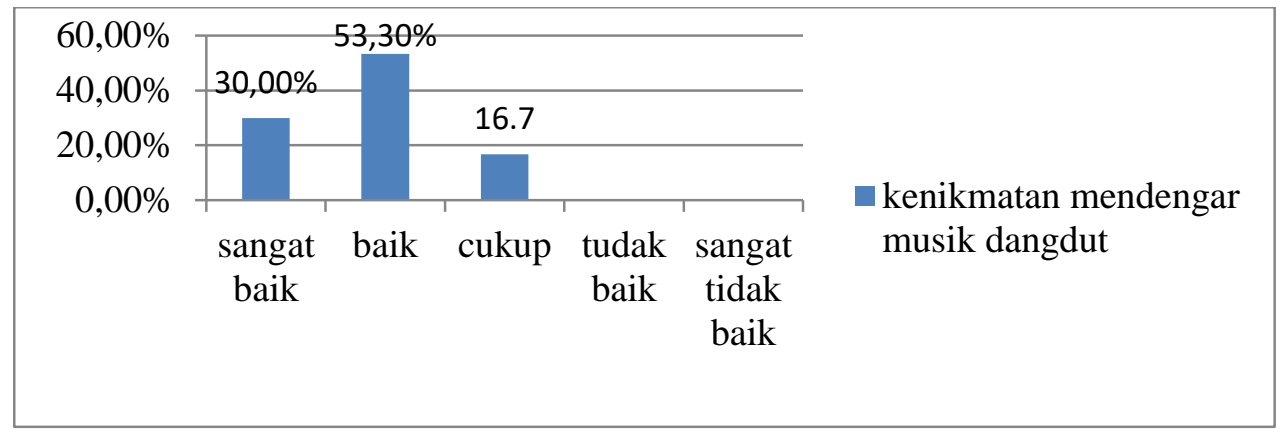

4. Tingkat motivasi mendengar musik dangdut karyawan Home Industry Trio

Berdasarkan hasil observasi di Home Industry Trio, diperoleh gambaran tentang tingkat motivasi mendengar musik dangdut karyawan sebagai berikut:

Tabel 4.10

Tingkat motivasi mendengar musik dangdut karyawan Home Industry Trio

\begin{tabular}{|c|c|c|c|}
\hline $\begin{array}{c}\text { Interval } \\
\text { persen }\end{array}$ & Kriteria & Frekuensi & Persentasi \\
\hline $86 \%-100 \%$ & Sangat baik & 15 & $50 \%$ \\
\hline $66 \%-85 \%$ & Baik & 13 & $43,3 \%$ \\
\hline $46 \%-65 \%$ & Cukup & 2 & $6,7 \%$ \\
\hline $26 \%-45 \%$ & Tidak baik & 0 & 0 \\
\hline $20 \%-35 \%$ & Sangat tidak baik & 0 & 0 \\
\hline \multicolumn{2}{|c|}{ Jumlah responden } & 30 & $100 \%$ \\
\hline \multicolumn{2}{|c|}{ Jumlah rata-rata skor } & \multicolumn{2}{|c|}{521} \\
\hline \multicolumn{2}{|c|}{ Jumlah skor rata rata ideal } & \multicolumn{2}{|c|}{600} \\
\hline \multicolumn{2}{|c|}{ Rata-rata } & \multicolumn{2}{|c|}{$86,8 \%$} \\
\hline
\end{tabular}

Berdasarkan tabel di atas dapat diketahui dari 30 sampel karyawan Home

Industry Trio diperoleh gambaran interval tingkat motivasi mendengar musik dangdut karyawan sebagai berikut: 
Sebanyak 15 karyawan (50\%) memiliki tingkat motivasi mendengar musik dangdut termasuk dalam kriteria sangat baik, 13 karyawan (43,3\%) memiliki tingkat motivasi mendengar musik dangdut termasuk dalam kriteria baik, 2 karyawan $(6,7 \%)$ memiliki tingkat motivasi mendengar musik dangdut termasuk dalam kriteria cukup, 0 karyawan (0\%) memiliki tingkat motivasi mendengar musik dangdut termasuk dalam kriteria tidak baik, dan 0 karyawan $(0 \%)$ memiliki tingkat motivasi mendenengar musik dangdut termasuk dalam kriteria sangat tidak baik. Secara klasikal persentasi tingkat motivasi mendengar musik dangdut karyawan Home Industry Trio sebesar 86,8\%, dan termasuk kedalam kriteria sangat baik.

Untuk lebih jelasnya dapat juga digambarkan dalam bentuk diagram batang distribusi seperti berikut:

\section{Diagram 4.10}

\section{Distribusi frekuensi tingkat motivasi mendengar musik dangdut}

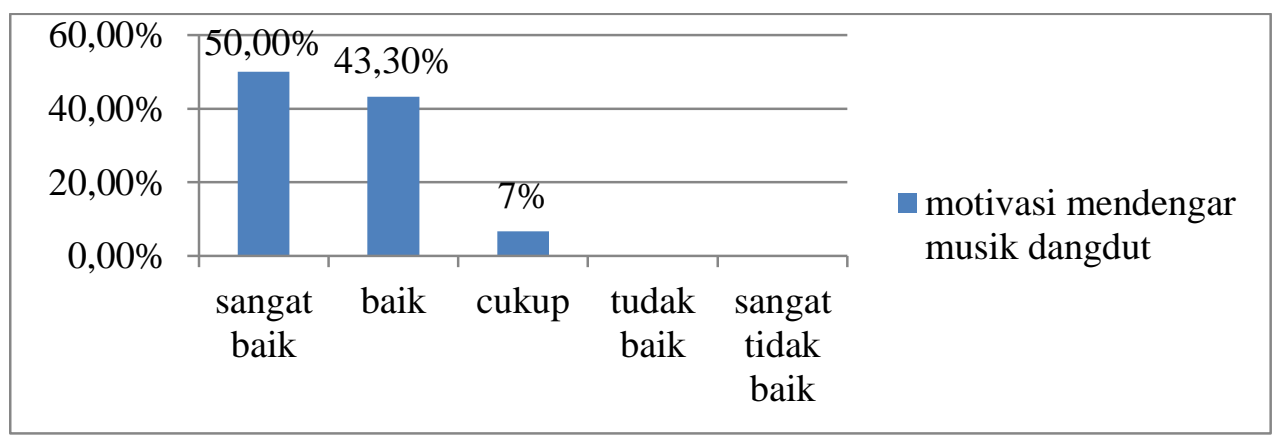

\subsubsection{Uji Prasyarat Analisis}

Hasil uji prasyarat analisis meliputi uji normalitas dan uji linieritas.

\subsubsection{Uji Normalitas}


Uji normalitas adalah uji untuk mengukur apakah data yang didapatkan memiliki distribusi normal sehingga dapat dipakai dalam statistik parametrik (statistic inferensial).

Tabel 4.11

Uji Normalitas Data

One-Sample Kolmogorov-Smirnov Test

\begin{tabular}{|ll|r|}
\hline & & $\begin{array}{r}\text { Unstandardiz } \\
\text { ed Residual }\end{array}$ \\
\hline Normal Parameters ${ }^{\mathrm{a}}$ & Mean & 30 \\
& Std. Deviation & 83.2500 \\
Most Extreme & Absolute & 9.18324 \\
Differences & Positive & .145 \\
& Negative & .075 \\
& &. .145 \\
Kolmogorov-Smirnov Z & & .796 \\
Asymp. Sig. (2-tailed) & & .550 \\
\hline
\end{tabular}

Berdasarkan hasil penghitungan menggunakan SPSS maka diperoleh nilai signifikan $=0,550>0,05$ artinya variabel Normal dan dapat di pakai dalam statistik parametrik.

\subsubsection{Uji Linieritas}


Uji linieritas berguna untuk mengetahui apakah penggunaan model regresi linier dalam penelitian ini tepat atau tidak. Hasilnya bisa dilihat pada tabel di bawah ini.

Tabel 4.12

\section{Uji Lineiritas Data}

ANOVA Table

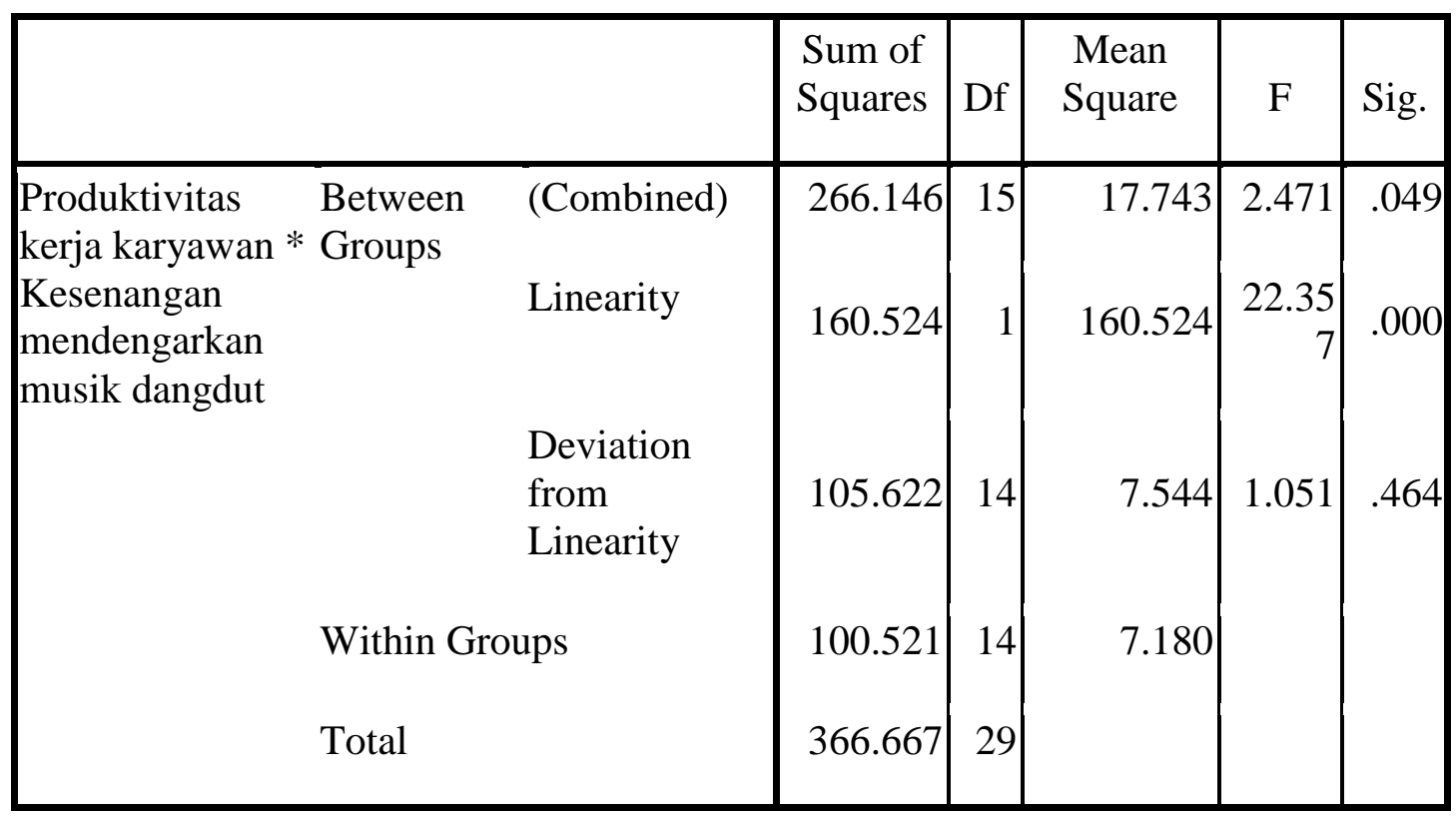

Pada tabel di atas diperoleh nilai $\mathrm{F}$ hitung $=1,051$ dengan nilai signifikan linierity $=0,000<0,05$ dengan demikian model regresi linier. Dengan kata lain model regresi linier dapat digunakan dalam peneltian ini

\subsubsection{Hasil Analisis Data}

Tujuan utama yang akan dicapai pada penelitian ini adalah untuk mengetahui adakah hubungan antara kesenangan mendengarkan musik dangdut dengan tingkat produktivitas karyawan Home Industry Trio di Desa Tegalwangi Kabupaten Tegal. 
Agar tercapainya tujuan tersebut maka perlu dilakukan suatu proses analisis data yang sudah diperoleh dari hasil penelitian berupa nilai pengisian angket tingkat kesenangan mendengarkan musik dangdut dan juga hasil penilaian tingkat produktivitas secara langsung yang dinilai oleh pimpinan Home Industry Trio. Analisis data yang digunakan pada penelitian kali ini yaitu dengan analisis uji hipotesis yang meliputi uji hipotesis 1 dan uji hipotesis 2.

\subsubsection{Uji Hipotesi 1}

Uji hipotesi 1 merupakan tahap dimana peneliti akan meneliti ada atau tidaknya korelasi antara kesenangan mendengarkan musik dangdut dengan tingkat produktivitas karyawan seperti berikut:

\subsection{Analisis Korelasi}

Uji korelasi digunakan untuk mengetahui ada atau tidaknya hubungan antara kesenangan mendengarkan musik dangdut dengan tingkat produktivitas karyawan Home Industry Trio. Berikut adalah output uji korelasi berdasarkan analisis dengan menggunakan program SPSS 16 for windows

Tabel 4.13

Analisis Korelasi 


\section{Correlations}

\begin{tabular}{|ll|r|r|}
\hline & \multicolumn{1}{|c|}{$\begin{array}{c}\text { Produktivitas } \\
\text { Karyawan }\end{array}$} & $\begin{array}{l}\text { Kesenangan } \\
\text { mendengarkan } \\
\text { musik dangdut }\end{array}$ \\
\hline Pearson Correlation & $\begin{array}{l}\text { Produktivitas Karyawan } \\
\text { Kesenangan } \\
\text { mendengarkan musik } \\
\text { dangdut }\end{array}$ & 1.000 & .662 \\
\hline Sig. (1-tailed) & $\begin{array}{l}\text { Produktivitas Karyawan } \\
\text { Kesenangan } \\
\text { mendengarkan musik } \\
\text { dangdut }\end{array}$ & .062 & 1.000 \\
\hline $\mathrm{N}$ & $\begin{array}{l}\text { Produktivitas Karyawan } \\
\text { Kesenangan } \\
\text { mendengarkan musik } \\
\text { dangdut }\end{array}$ & 30 & .000 \\
\hline
\end{tabular}

Tabel di atas diperoleh nilai korelasi $0,662>\mathrm{r}$ tabel $=0,361$. jadi dengan demikian dapat diputuskan bahwa Ho yang berbunyi Tidak terdapat korelasi positif dan signifikan antara kesenangan mendengarkan musik terhadap tingkat produktivitas karyawan Home Industry Trio Desa Tegalwangi Kabupaten Tegal, ditolak dan menerima Ha yang berbunyi: Terdapat korelasi positif dan signifikan antara kesenangan mendengarkan musik dengan tingkat produktivitas karyawan Home Industry Trio Desa Tegalwangi Kabupaten Tegal, dan dapat disimpulkan terdapat 
hubungan yang signifikan antara kesenangan mendengarkan musik dangdut dengan tingkat produktivitas karyawan Home Industry Trio.

\subsection{Koefisien determinasi ganda (R2)}

Untuk mengetahui seberapa besar kontribusi kesenangan mendengarkan musik dangdut terhadap tingkat produktivitas karyawan dapat dilihat dalam tabel model summary seperti di bawah ini:

Tabel 4.14

Uji Determinasi

Model Summary ${ }^{b}$

\begin{tabular}{|c|c|c|c|c|c|c|c|c|c|}
\hline \multirow[b]{2}{*}{$\begin{array}{l}\text { Mo } \\
\text { del }\end{array}$} & \multirow[b]{2}{*}{$\mathrm{R}$} & \multirow[b]{2}{*}{$\begin{array}{c}\mathrm{R} \\
\text { Squar } \\
\mathrm{e}\end{array}$} & \multirow[b]{2}{*}{$\begin{array}{l}\text { Adjusted } \\
\text { R Square }\end{array}$} & \multirow[b]{2}{*}{\begin{tabular}{|c} 
Std. \\
Error of \\
the \\
Estimate
\end{tabular}} & \multicolumn{5}{|c|}{ Change Statistics } \\
\hline & & & & & $\begin{array}{c}\text { R Square } \\
\text { Change }\end{array}$ & $\begin{array}{c}\mathrm{F} \\
\text { Chang } \\
\mathrm{e}\end{array}$ & df1 & df2 & $\begin{array}{c}\text { Sig. F } \\
\text { Change }\end{array}$ \\
\hline 1 & $.662^{\mathrm{a}}$ & .438 & .418 & 2.71335 & .438 & 21.804 & 1 & 28 & .000 \\
\hline
\end{tabular}

Pada tabel di atas diperoleh nilai Adjusted $\mathrm{R}^{2}=0,418=41,8 \%$, ini berarti besarnya kontribusi kesenangan mendengarkan musik dangdut dengan tingkat produktivitas karyawan Home Industry Trio Desa Tegalwangi Kabupaten Tegal sebesar $41,8 \%$. Selebihnya yang tingkat produktivitas karyawan dipengaruhi oleh variabel atau faktor-faktor lain selain kesenangan mendengarkan musik yang tidak di ikut sertakan pada penelitian kali ini.

\subsubsection{Uji Hipotesis 2}


Uji hipotesis 2 merupakan tahap dimana peneliti akan meneliti ada atau tidaknya pengaruh kesenangan mendengarkan musik dangdut dengan tingkat produktivitas karyawan dengan model regresi seperti berikut:

\subsection{Persamaan Regresi}

Untuk mengetahui ada atau tidaknya pengaruh kesenangan mendengarkan musik dangdut terhadap tingkat produktifitas karyawan, dapat digunakan analisis regresi dengan menggunakan program SPSS 16 for windows seperti terangkum pada tabel berikut:

Tabel 4.15

\section{Persamaan Regresi}

\section{Coefficients $^{\mathrm{a}}$}

\begin{tabular}{|c|c|c|c|c|c|c|c|c|}
\hline \multirow[b]{2}{*}{ |Model } & \multicolumn{2}{|c|}{$\begin{array}{c}\text { Unstandardized } \\
\text { Coefficients }\end{array}$} & \multirow{2}{*}{$\begin{array}{c}\begin{array}{c}\text { Standard } \\
\text { ized } \\
\text { Coefficie } \\
\text { nts }\end{array} \\
\text { Beta }\end{array}$} & \multirow[b]{2}{*}{$\mathrm{T}$} & \multirow[b]{2}{*}{ Sig. } & \multicolumn{3}{|c|}{ Correlations } \\
\hline & B & $\begin{array}{l}\text { Std. } \\
\text { Error }\end{array}$ & & & & $\begin{array}{l}\text { Zero- } \\
\text { order }\end{array}$ & $\begin{array}{c}\text { Partia } \\
1\end{array}$ & Part \\
\hline $1 \quad$ (Constant $)$ & 53.255 & 4.594 & & 11.59 & .000 & & & \\
\hline $\begin{array}{l}\text { Kesenangan } \\
\text { mendengarkan } \\
\text { musik dangdut }\end{array}$ & .256 & .055 & .662 & 4.669 & .000 & .662 & .662 & .662 \\
\hline
\end{tabular}

a. Dependent Variable: Produktivitas

Karyawan 
Berdasarkan tabel 4.13 di atas diperoleh persamaan regresi berganda sebagai berikut:

$$
\dot{\mathbf{Y}}=\mathbf{5 3}, 225+\mathbf{0 , 2 5 6} \mathrm{X}
$$

Persamaan tersebut bisa diartikan jika variabel kesenangan mendengarkan musik dangdut meningkat 1 satuan maka tingkat produktivitas karyawan meningkat sebesar 0,256 satuan pada konstanta 53,225.

Hasil pengujian statistik dengan SPSS pada variabel $\mathrm{X}$ (kesenangan mendengarkan musik dangdut) diperoleh nilai $t_{\text {hitung }}=4,669$ dan sig $0,000<0,005$. Dengan demikian dapat disimpulkan Ho yang berbunyi tidak ada pengaruh positif dan signifikan antara kesenangan mendengarkan musik terhadap tingkat produktivitas karyawan Home Industry Trio Desa Tegalwangi Kabupaten Tegal, ditolak dan menerima Ha yang berbunyi ada pengaruh positif dan signifikan antara kesenangan mendengarkan musik terhadap tingkat produktivitas karyawan Home Industry Trio Desa Tegalwangi Kabupaten Tegal.

\subsection{Pembahasan}

Kesenangan karyawan mendengarkan musik dangdut pada saat bekerja bisa dipengaruhi oleh beberapa faktor, baik itu dari diri sendiri, rekan kerja, maupun kondisi atau lingkungan di sekitar pekerjaan. Musik yang mengalun dapat menambah semangat kerja seseorang karena menimbulkan suasana yang gembira dan tidak membosankan (Nitisemito, 2002: 56). Hasil perhitungan deskriptif persentase menunjukan tingkat kesenangan mendengarkan musik dangdut karyawan Home Industry Trio Desa Tegalwangi Kabupaten Tegal termasuk dalam kategori tinggi yaitu 83,25\%. Hasil yang 
begitu tinggi menunjukan bahwa mendengarkan musik dangdut sudah menjadi kebutuhan karyawan sebagai pengiring kerja.

Data tingkat kesenangan mendengarkan musik dangdut karyawan Home Industry Trio tersebut diperoleh dari pembagian angket dengan 30 responden. Didalamnya meliputi 16 butir pertanyaan yang terbagi menjadi dua tipe positif dan negatif yang meliputi 4 indikator yang mempengaruhi tingkat kesenangan mereka yang dapat diukur dari: kegemaran, kepuasan hati, kenikmatan, dan motivasi. Hasil perhitungan deskriptif persentase pada keempat indikator tersebut meunjukan hasil yang begitu signifikan dan masuk kedalam kategori baik.

"Kesenangan adalah kepuasan hati, kelegaan, kesukaan, kenikmatan, kenyamanan, kebahagiaan (Depdikbud, 1991: 910)”. Kesenangan karyawan mendengarkan musik dangdut terbukti dengan selelu mendengarkan musik dangdut saat bekerja. Tape dan sound system yang disediakan oleh pemimpin Home Industry Trio selelu menyala pada saat bekerja dan hanya berhenti ketika jam istirahat. Cara mereka menikmatinya bisa dilihat dari kebiasaan mengikuti irama lagu dan ikut menyanyikannya sambil bekerja, bahkan tak jarang pula sambil menari mengikuti irama. Kondisi seperti itu yang diharpakan oleh pemimpin Home Industry sehingga karyawan merasa puas dan termotivasi agar tetap semangat saat bekerja dan menyelesaikan target produksi tanpa merasakan beban. Hasil penelitian menunjukan bahwa kesenangan mendengarkan musik dangdut berpengaruh terhadap tingkat produktivitas karyawan Home Industry Trio Desa Tegalwangi Kabupaten Tegal. Besarnya pengaruh kesenangan mendengarkan musik dangdut terhadap tingkat 
produktivitas karyawan adalah 41,8\%. Hasil ini menunjukan bahwa kesenangan mendengarkan musik merupakan faktor yang cukup dominan dalam meningkatkan tingkat produktivitas karyawan. Tapi bukanlah satu-satunya faktor yang mempengaruhi tingkat produktivitas, selebihnya bisa dipengaruhi oleh faktor-faktor lain yang tidak diikut sertakan pada penelitian kali ini seperti: latar belakang kebudayan dan pendidikan, bakat, pengalaman, usia maupun jenis kelamin.

Latar belakang budaya dan pendidikan, pada dasarnya setiap manusia memiliki latar belakang kebudayaan dan pendidikan yang berbeda-beda. Menurut (Soerjanto Poespowardojo, 1993: 63) Budaya adalah keseluruhan sistem gagasan tindakan dan hasil karya manusia dalam rangka kehidupan masyarakat yang dijadikan miliki diri manusia dengan cara belajar. dari berbagai proses belajar itulah yang kemudian akan membentuk karakter seseorang sehingga menjadi manusia yang berpotensi menjadi manusia yang produktiv. Faktor yang lainnya yaitu bakat, Nurkancana 1993: 191), mengatakan bahwa: Bakat adalah suatu kualitas yang nampak pada tingkah laku manusia pada suatu lapangan keahlian tertentu seperti musik, seni mengarang, kecakapan dalam matematika, keahlian dalam bidang mesin, atau keahlian-keahlian lainnya. Dalam kaitanya dengan dunia kerja orang yang memiliki bakat cenderung lebih produktiv dari pada yang tidak berbakat sama sekali. Kemudian faktor lain yang selanjutnya yaitu Pengalaman, Usia, dan jenis kelamin, ketiga faktor ini sangatlah berkaitan, semakin banyak pengalaman biasanya semakin tua juga usia seseorang, tetapi semakin tua seseorang belum tentu semakin produtiv. Dalam dunia kerja pria cenderung lebih sering dikatakan lebih produktiv dari pada wanita, karena ketahanan 
fisik dan tenaga pria cenderung lebih besar dari pada wanita, hal inilah yang menjadi salah satu faktor yang mempengaruhi tingkat produktivias manusia.

Penilaian tingkat produktivitas pada penelitian diambil dari borang penilaian kinerja karyawan yang didalamnya terdapat 4 kriteria penilaian meliputi: Absensi, disiplin, target, dan kualitas (Rusli Syarif, 1991: 7). Pada perhitungan deskriptif persentase rata-rata tingkat produktivitas karyawan Home Industry Trio Desa Tegalwangi Kabupaten Tegal, menunjukan hasil yang begitu tinggi yaitu 74,6\%. Begitu pula dengan tiap-tiap indikator yang menunjukan hasil yang cukup baik dengan hasil persentase terendah yaitu 73,6\% masuk kedalam kategori baik. Hasil penelitian ini menunjukan bahwa kebiasaan karyawan mendengarkan musik dangdut sebagai pengiring saat bekerja di Home Industry Trio sangatlah berpengaruh terhadap tingkat produktivitas mereka, walaupun ada beberapa karyawan yang tidak terlalu menyukai musik dangdut tapi kondisi seperti itu sudah bisa toleransi karena memang sudah menjadi kebiasaan dan hal yang wajib bagi mayoritas besar karyawan disana. Karyawan yang menyukai musik dangdut cenderung mendapat nilai produktivitas lebih baik dari pada yang kurang menyukai musik dangdut. Di Home Industry Trio tingkat kesenangan mendengarkan musik dangdut berpengaruh terhadap tingkat produktivitas sebesar 41,8\%. Hal tersebut menunjukan kesenangan mendengarkan musik bukanlah satu-satunya faktor yang mempengaruhi tingkat produktivitas karyawan, melainkan masih banyak lagi faktor lain yang mempengaruhi produktivitas selain dilihat dari segi kebutuhan manusia antara lain seperti menurut (sinungan, 2000; 23) yaitu: (1) Modal; yang terdiri dari modal tetap (mesin, gedung, alat-alat, volume dan standar), 
strukturnya, tehnologi, litbang, dan bahan baku (volume dan standar), (2) Metode atau proses baik tata ruang tugas, penanganan bahan baku penolong dan mesin, perencanaan dan pengawasan produksi, pemeliharan melalui pencegahan, teknologi yang memakai cara alternatif, (3) Produksi yang meliputi: kuantitas, kualitas, ruangan produksi, struktur campuran, dan 3 spesial produksi, (4) Lingkungan Organisasi (internal) berupa: organisasi dan perencanaan, sistem manajemen, kondisi kerja (fisik), iklim kerja (sosial), tujuan perusahaan dan hubungannya dengan tujuan lingkungan, sistem insentif, kebijaksanaan pearsonalia, gaya kepemimpinan dan ukuran perusahaan (ekonomi skala), (5) Lingkungan Negara (eksternal) seperti; kondisi ekonomi dan perdagangan struktur sosial dan politik, struktur industri, tujuan pengembangan jangka panjang, pengakuan atau pengesahan, kebijaksanaan ekonomi pemerintah (perpajakan dan lain-lain), kebijakan tenaga kerja, energi, kebijakan pendidikan dan latihan, kondisi iklim dan geografis serta kebijakan perlindungan lingkungan, (6) Lingkungan Internasional (regional) yang terdiri dari: kondisi perdagangan dunia, masalah-masalah perdagangan internasional spesialisasi internasional, kebijakan migrasi tenaga kerja,dan standar tenaga kerja, (7) Umpan balik yaitu informasi yang ada hubungannya dengan timbal balik masukan (input) dan hasil (output) dalam perusahaan, antara perusahaan dengan ruang lingkup Negara (internasioanal).

\section{BAB 5}




\section{PENUTUP}

\subsection{Kesimpulan}

Setelah melaksanakan penelitian tentang Hubungan Antara Kesenangan Mendengarkan Musik Dangdut dengan Tingkat Produktivitas Karyawan Home Industry Trio Desa Tegalwangi Kabupaten Tegal maka diputuskan Ho yang berbunyi Tidak terdapat korelasi positif dan signifikan antara kesenangan mendengarkan musik terhadap tingkat produktivitas karyawan Home Industry Trio Desa Tegalwangi Kabupaten Tegal, ditolak dan menerima Ha yang berbunyi: Terdapat korelasi positif dan signifikan antara kesenangan mendengarkan musik dengan tingkat produktivitas karyawan Home Industry Trio Desa Tegalwangi Kabupaten Tegal, sehingga dapat ditarik kesimpulan terdapat hubungan yang signifikan antara kesenangan mendengarkan musik dangdut dengan tingkat produktivitas karyawan Home Industry Trio dengan nilai korelasi 0,662 >0,361.

Terdapat pengaruh antara kesenangan mendengarkan musik dangdut dengan tingkat produktivitas karyawan Home Industry Trio Desa Tegalwangi Kabupaten Tegal dengan persamaan regresi $\mathrm{Y}=53,225+0,256 \mathrm{X}$. Persamaan tersebut bisa diartikan jika variabel kesenangan mendengarkan musik dangdut meningkat 1 satuan maka tingkat produktivitas karyawan meningkat sebesar 0,256 satuan pada konstanta 53,225. 
Besarnya kontribusi kesenangan mendengarkan musik dangdut terhadap tingkat produktivitas karyawan Home Industry Trio Desa Tegalwangi Kabupaten Tegal yaitu sebesar $41,8 \%$.

\subsection{Saran}

Saran yang dapat diberikan setelah melakukan penelitian ini adalah sebagai berikut:

Melihat dari hasil penelitian ini bahwa tingkat kesenangan mendengarkan musik dangdut berhubungan dengan tingkat produktivitas karyawan Home Industry Trio Desa Tegalwangi Kabupaten Tegal, maka disarankan kepada karyawan perusahaan agar tetep mempertahankan kegiatan mendengarkan musik sebagai pengiring bekerja, karena terbukti terdapat hubungan yang signifikan bahwa kesenangan mendengarkan musik dangdut berpengaruh terhadap tingkat produktivitas.

Bagi pihak pimpinan Home Industry Trio hendaknya lebih meningkatkan fasilitas-fasilitas yang menunjang produktivitas karyawan bagi dari segi tempat yang nyaman maupun hak-hak yang harus didapat oleh karyawan yang lain agar terjadi hubungan saling menguntungkan antara pihak yang satu dengan yang lainnya.

Besarnya pengaruh tingkat kesenangan mendengarrkan musik dangdut terhadap tingkat produktivitas karyawan Home Industry Trio Desa Tegalwangi Kabupaten Tegal cukup besar, yaitu 41,8\%. Berarti masih ada variabel variabel lain yang bisa mempengaruhi tingkat produkivitas, maka saran dari penulis yaitu perlu dilakukan lagi penelitian lain untuk mengetahui variabel selain kesenangan mendengarkan musik yang mempengaruhi tingkat produktivitas. 


\section{DAFTAR PUSTAKA}

Akbar, Ali. 2007. Sistem Automatic Music Emotion Clasification. Bandung ITB 
Andaryani, E. (2013). PERSEPSI MASYARAKAT TERHADAP PERTUNJUKAN MUSIK DANGDUT ORGAN TUNGGAL. Harmonia: Journal of Arts Research and Education, 11(2). doi:https://doi.org/10.15294/harmonia.v11i2.2209

Arikunto, Suharsimi. 2013. Prosedur Penelitian. Penerbit PT. Rineka Cipta. Jakarta.

Depdikbud. 1991. Kamus Besar Bahasa Indonesia Edisi kedua. Jakarta: BalaiPustaka

Fraenkel, Jack R. dan Norman E.Wallen (2008), How to Design and Evalute Researche in Education, 7th ed. The Mc Graw-Hil, New York, NY.

Hadi, S. 2001. Statistika jilid 2. Yogyakarta: Andi

Hadeli, 2006, Metode Penelitian Pendidikan, Jakarta, Quantum Teaching.

Hasibuan, Malayu S.P. 2005. Manajemen Sumber Daya Manusia, Edisi Revisi. Bumi Aksara, Jakarta.

Hoetomo, Kamus Lengkap Inggris Indnesia, Penerbit Mitra Pelajar Surabaya. Tahun 2005

Muttaqin, M. (2011). Musik Dangdut dan Keberadaannya di Masyarakat : Tinjauan dari Segi Sejarah dan Perkembangannya (Dangdut and Its Existence in the Society :The Review of Its History and Development ). Harmonia: Journal of Arts Research and Education, 7(2). doi:https://doi.org/10.15294/harmonia.v7i2.755

Muttaqin, M. (2011). Musik Dangdut dan Keberadaannya di Masyarakat : Tinjauan dari Segi Sejarah dan Perkembangannya (Dangdut and Its Existence in the Society :The Review of Its History and Development ). Harmonia: Journal of Arts Research and Education, 7(2). doi:https://doi.org/10.15294/harmonia.v7i2.755

Wadiyo, -. (2011). Musik Dangdut di Kalangan Remaja Kota Semarang (Dangdut Music of Adolescent Society in Semarsmg City). Harmonia: Journal of Arts Research and Education, 5(3). doi:https://doi.org/10.15294/harmonia.v5i3.819

Mangkunegara, Awan P. 2005. Evaluasi Kinerja. Bandung : Refika Aditama 
Margono,S. Metodologi Penelitian Pendidikan. 2005. Jakarta : Rineka Cipta.

Merriam, Alan P , 1964, The Anthropology of Music, Northwestern University Press: Chicago.

Miller, Hugh M., 1958, Introduction to Music; a Guide to Good Listening, penerjemah: Drs. Triyono Bramantyo PS;

Nawawi. Hadari, 2003. Perencanaan SDM Untuk Organisasi Profit Yang Kompetitif, Edisi Pertama, Cetakan Pertama, Gadjah Mada University Press, Yogyakarta,

Nitisemito Alex S., 2002. Manajemen Pearsonalia (Manajemen Sumber Daya Manusia), Edisi ketiga: Ghalia Indonesia, Jakarta.

Nurkancana, Wayan dan P.P.N. Sunartana. 1990. Evaluasi Pendidikan. Surabaya: Usaha Nasional

Poespowardojo, Soerjanto. 1993. Strategi Kebudayaan Suatu Pendekatan Filosofis. Jakarta : Gramedia Pustaka Utama.

Poerwadarminta. 1989. Kamus Besar Bahasa Indonesia. Balai Pustaka: Jakarta.

Rachmad. 2011. Artikel pengertian musik dangdut. Diunduh di http://id.wikipedia.org/wiki/Dangdut

Ravianto, J. (1986), Produktivitas dan Manusia Indonesia. Jakarta. Siup

Rusli Syarif, (1991) Produktivitas, Angkasa Bandung,

Riyanto, J. 1986. Produktivitas dan Tenaga Kerja. SIUP: Jakarta.

Sinungan, Muchdarsyah. (2003). Produktivitas apa dan Bagaimana. Jakarta: Bumi Aksara

Sugiyono. 2004. Metode Penelitian Bisnis. Bandung : CV. Alfabeta.

Suharto. (2000). Peran Seni dalam Pengoptimalan Fungsi Otak.Lingua Artistika, 23

(3), 400-411. 
Suharto. (1991). Bayangan Nada sebagai Materi bagi Pembelajar Pemula. Jurnal Media, 18 (2).

Sukamto. 1995. Manajemen Produksi Replasi.Yogyakarta: BPFE UGM.

Sukarna. (1993), Kepemimpinan dalam Organisasi. Penerbit Mandar Maju, Bandung.

The Liang Gie, 1981. Efisiensi Kerja Bagi Pembangunan Negara, Jakarta: PT. Gunung Agung.

Lampiran 1

\section{DATA NILAI PRODUKTIVITAS KARYAWAN \\ HOME INDUSTRY TRIO}

TAHUN 2016

\begin{tabular}{|l|l|l|c|c|c|c|c|}
\hline No. & Nama & Bagian & \multicolumn{3}{|c|}{ Aspek Penilaian } & \multirow{2}{*}{$\begin{array}{c}\text { Rata } \\
\text { rata }\end{array}$} \\
\cline { 4 - 7 } & & & Absensi & Disiplin & Target & Kualitas & \\
\hline 1. & Wiwit & Bubut & 70 & 80 & 85 & 80 & 78.75 \\
\hline 2. & Udin & Bubut & 85 & 85 & 80 & 80 & 82.50 \\
\hline
\end{tabular}




\begin{tabular}{|c|c|c|c|c|c|c|c|}
\hline 3. & Doni & Bor & 70 & 70 & 75 & 75 & 72.50 \\
\hline 4. & Andri & Bor & 75 & 70 & 70 & 75 & 72.50 \\
\hline 5. & Towo & Pengecoran & 75 & 75 & 70 & 70 & 72.50 \\
\hline 6. & Ikhfar & Pengecoran & 75 & 70 & 70 & 75 & 72.50 \\
\hline 7. & Aswin & Bubut & 75 & 75 & 70 & 70 & 72.50 \\
\hline 8. & Basir & Poles & 80 & 80 & 70 & 75 & 76.25 \\
\hline 9. & Parjo & Poles & 75 & 75 & 75 & 70 & 73.75 \\
\hline 10 & Agus & Gerinda & 75 & 75 & 70 & 70 & 72.50 \\
\hline 11. & Tomas & Repair & 80 & 80 & 80 & 80 & 80.00 \\
\hline 12. & Barok & Pengecatan & 70 & 70 & 70 & 75 & 71.25 \\
\hline 13. & Opik & Pengecatan & 70 & 70 & 70 & 70 & 70.00 \\
\hline 14. & Bambang & Pengemasan & 70 & 80 & 85 & 80 & 78.75 \\
\hline 15. & Rumli & Pengemasan & 70 & 75 & 80 & 75 & 75.00 \\
\hline 16 & Tio & Welding & 80 & 80 & 75 & 70 & 76.25 \\
\hline 17. & Rojikin & Pengecatan & 85 & 85 & 85 & 80 & 83.75 \\
\hline 18. & Paung & Welding & 75 & 75 & 70 & 70 & 72.50 \\
\hline 19. & Lukman & Bending & 70 & 70 & 70 & 75 & 71.25 \\
\hline 20. & Toni & Bending & 80 & 80 & 70 & 75 & 76.25 \\
\hline 21. & Bayu & Bending & 75 & 75 & 70 & 70 & 72.50 \\
\hline 22 & Ozan & Welding & 70 & 75 & 70 & 70 & 71.25 \\
\hline 23. & $\mathrm{Aji}$ & Poles & 70 & 70 & 75 & 75 & 72.50 \\
\hline 24 & Rokhman & Mesin Pon & 80 & 80 & 75 & 70 & 76.25 \\
\hline 25 & Danar & Mesin Pon & 75 & 75 & 70 & 70 & 72.50 \\
\hline 26. & Afan & Mesin Pon & 75 & 75 & 70 & 70 & 72.50 \\
\hline 27. & Idin & Las Asitilin & 75 & 75 & 75 & 70 & 73.75 \\
\hline 28. & Dika & Las Asitilin & 70 & 70 & 70 & 70 & 70.00 \\
\hline 29. & Sugeng & Bor & 80 & 80 & 75 & 80 & 78.75 \\
\hline
\end{tabular}




\begin{tabular}{|l|l|l|l|l|l|l|l|}
\hline 30. & Santo & Repair & 75 & 75 & 80 & 75 & 76.25 \\
\hline
\end{tabular}

Skala:

\begin{tabular}{|l|l|}
\hline $10-25$ & Tidak memuaskan \\
\hline $26-50$ & Kurang \\
\hline $51-75$ & Cukup Memuaskan \\
\hline $76-100$ & Sangat Memuaskan \\
\hline
\end{tabular}

Mengetahui,

Pimpinan Home Industry Trio.

H. Rasbin Bin Sarkadi

Lampiran 2

DATA MENTAH ANGKET KESENANGAN MENDENGARKAN MUSIK DANGDUT 


\begin{tabular}{|c|c|c|c|c|c|c|c|c|c|c|c|c|c|c|c|c|}
\hline \multirow{2}{*}{ Kode } & \multicolumn{16}{|c|}{ No Item } \\
\hline & 1 & 2 & 3 & 4 & 5 & 6 & 7 & 8 & 9 & 10 & 11 & 12 & 13 & 14 & 15 & 16 \\
\hline $\mathrm{R}-01$ & 5 & 5 & 3 & 5 & 5 & 5 & 5 & 5 & 3 & 4 & 4 & 4 & 5 & 5 & 5 & 5 \\
\hline $\mathrm{R}-02$ & 5 & 5 & 5 & 5 & 5 & 5 & 5 & 5 & 2 & 4 & 5 & 5 & 5 & 5 & 5 & 5 \\
\hline R-03 & 3 & 4 & 2 & 4 & 4 & 4 & 3 & 4 & 5 & 3 & 4 & 4 & 3 & 4 & 4 & 4 \\
\hline R-04 & 4 & 5 & 2 & 5 & 4 & 4 & 4 & 4 & 5 & 4 & 4 & 5 & 5 & 5 & 4 & 5 \\
\hline R-05 & 4 & 4 & 3 & 5 & 4 & 4 & 4 & 5 & 3 & 3 & 4 & 4 & 3 & 4 & 5 & 4 \\
\hline R-06 & 4 & 4 & 4 & 4 & 4 & 4 & 4 & 5 & 4 & 4 & 4 & 4 & 5 & 5 & 5 & 5 \\
\hline R-07 & 4 & 4 & 3 & 4 & 4 & 4 & 5 & 4 & 3 & 4 & 4 & 4 & 4 & 4 & 4 & 4 \\
\hline R-08 & 4 & 5 & 4 & 4 & 5 & 5 & 4 & 5 & 5 & 4 & 4 & 5 & 4 & 5 & 3 & 5 \\
\hline R-09 & 4 & 4 & 4 & 4 & 4 & 4 & 4 & 5 & 4 & 3 & 4 & 4 & 4 & 4 & 5 & 5 \\
\hline $\mathrm{R}-10$ & 4 & 5 & 3 & 5 & 4 & 3 & 4 & 5 & 4 & 3 & 4 & 4 & 4 & 4 & 5 & 4 \\
\hline $\mathrm{R}-11$ & 5 & 4 & 4 & 4 & 5 & 4 & 4 & 4 & 5 & 5 & 5 & 5 & 5 & 5 & 5 & 4 \\
\hline $\mathrm{R}-12$ & 3 & 3 & 3 & 4 & 3 & 3 & 3 & 4 & 2 & 2 & 4 & 4 & 3 & 3 & 3 & 4 \\
\hline $\mathrm{R}-13$ & 5 & 5 & 4 & 4 & 4 & 4 & 4 & 5 & 4 & 4 & 5 & 4 & 3 & 4 & 4 & 4 \\
\hline $\mathrm{R}-14$ & 5 & 5 & 4 & 4 & 5 & 4 & 4 & 4 & 5 & 5 & 5 & 5 & 4 & 4 & 4 & 4 \\
\hline $\mathrm{R}-15$ & 3 & 5 & 2 & 5 & 4 & 5 & 2 & 4 & 5 & 4 & 4 & 5 & 4 & 5 & 4 & 5 \\
\hline $\mathrm{R}-16$ & 5 & 4 & 3 & 4 & 5 & 5 & 5 & 5 & 4 & 4 & 4 & 4 & 5 & 5 & 4 & 4 \\
\hline $\mathrm{R}-17$ & 5 & 4 & 4 & 5 & 5 & 5 & 5 & 5 & 5 & 5 & 5 & 5 & 5 & 5 & 5 & 5 \\
\hline $\mathrm{R}-18$ & 4 & 4 & 4 & 5 & 3 & 4 & 4 & 5 & 4 & 4 & 4 & 4 & 4 & 4 & 4 & 4 \\
\hline R-19 & 3 & 3 & 2 & 3 & 2 & 4 & 3 & 4 & 2 & 2 & 4 & 3 & 4 & 3 & 2 & 4 \\
\hline $\mathrm{R}-20$ & 4 & 4 & 3 & 5 & 4 & 4 & 4 & 5 & 3 & 4 & 4 & 4 & 4 & 4 & 5 & 5 \\
\hline $\mathrm{R}-21$ & 4 & 4 & 3 & 5 & 3 & 5 & 2 & 5 & 2 & 2 & 5 & 4 & 5 & 5 & 5 & 4 \\
\hline $\mathrm{R}-22$ & 3 & 4 & 3 & 4 & 4 & 3 & 2 & 4 & 2 & 3 & 3 & 4 & 4 & 4 & 4 & 4 \\
\hline $\mathrm{R}-23$ & 5 & 5 & 4 & 5 & 5 & 5 & 5 & 5 & 5 & 4 & 5 & 5 & 5 & 5 & 5 & 5 \\
\hline R-24 & 5 & 5 & 4 & 5 & 5 & 5 & 5 & 5 & 5 & 5 & 5 & 5 & 5 & 5 & 5 & 5 \\
\hline $\mathrm{R}-25$ & 4 & 4 & 4 & 4 & 4 & 4 & 3 & 4 & 3 & 3 & 4 & 4 & 3 & 3 & 4 & 4 \\
\hline $\mathrm{R}-26$ & 5 & 5 & 4 & 4 & 4 & 4 & 3 & 5 & 3 & 3 & 4 & 4 & 4 & 4 & 4 & 4 \\
\hline $\mathrm{R}-27$ & 4 & 4 & 3 & 5 & 4 & 4 & 4 & 4 & 4 & 4 & 4 & 4 & 4 & 4 & 5 & 4 \\
\hline $\mathrm{R}-28$ & 5 & 4 & 4 & 5 & 4 & 5 & 4 & 5 & 4 & 4 & 4 & 1 & 5 & & 3 & 5 \\
\hline R-29 & 4 & 5 & 5 & 5 & 5 & 5 & 1 & 4 & 4 & 4 & 5 & 5 & 4 & 5 & 5 & 5 \\
\hline $\mathrm{R}-30$ & 4 & 5 & 3 & 4 & 4 & 5 & 4 & 4 & 4 & 4 & 4 & 5 & 5 & 5 & 4 & 5 \\
\hline
\end{tabular}


Lampiran 3

\begin{tabular}{|c|c|c|c|c|c|c|c|c|c|c|c|c|c|c|c|c|c|c|c|c|}
\hline \multicolumn{21}{|c|}{ UJI VALIDITAS DAN RELIABILITAS ANGKET KESENANGAN MENDENGARKAN MUSIK DANGDUT } \\
\hline \multirow{2}{*}{$\begin{array}{c}\mathrm{N} \\
0 \\
0\end{array}$} & \multirow[b]{2}{*}{ Kode } & \multicolumn{16}{|c|}{ No Item } & \multirow[b]{2}{*}{ Y } & \multirow{2}{*}{\multicolumn{2}{|c|}{$\mathrm{Y}^{2}$}} \\
\hline & & 1 & 2 & 3 & 4 & 5 & 6 & 7 & 8 & 9 & 10 & 11 & 12 & 13 & 14 & 15 & 16 & & & \\
\hline 1 & R-01 & 5 & 5 & 3 & 5 & 5 & 5 & 5 & 5 & 3 & 4 & 4 & 4 & 5 & $\frac{17}{5}$ & 5 & 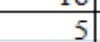 & 73 & & 5329 \\
\hline 2 & R-02 & 5 & 5 & 5 & 5 & 5 & 5 & 5 & 5 & 2 & 4 & 5 & 5 & 5 & 5 & 5 & 5 & 76 & & 5776 \\
\hline 3 & R-03 & 3 & 4 & 2 & 4 & 4 & 4 & 3 & 4 & 5 & 3 & 4 & 4 & 3 & 4 & 4 & 4 & 59 & & 3481 \\
\hline 4 & R-04 & 4 & 5 & 2 & 5 & 4 & 4 & 4 & 4 & 5 & 4 & 4 & 5 & 5 & 5 & 4 & 5 & 69 & & 4761 \\
\hline 5 & R-05 & 4 & 4 & 3 & 5 & 4 & 4 & 4 & 5 & 3 & 3 & 4 & 4 & 3 & 4 & 5 & 4 & 63 & & 3969 \\
\hline 6 & R-06 & 4 & 4 & 4 & 4 & 4 & 4 & 4 & 5 & 4 & 4 & 4 & 4 & 5 & 5 & 5 & 5 & 69 & & 4761 \\
\hline 7 & R-07 & 4 & 4 & 3 & 4 & 4 & 4 & 5 & 4 & 3 & 4 & 4 & 4 & 4 & 4 & 4 & 4 & 63 & & 3969 \\
\hline 8 & R-08 & 4 & 5 & 4 & 4 & 5 & 5 & 4 & 5 & 5 & 4 & 4 & 5 & 4 & 5 & 3 & 5 & 71 & & 5041 \\
\hline 9 & R-09 & 4 & 4 & 4 & 4 & 4 & 4 & 4 & 5 & 4 & 3 & 4 & 4 & 4 & 4 & 5 & 5 & 66 & & 4356 \\
\hline 10 & R-10 & 4 & 5 & 3 & 5 & 4 & 3 & 4 & 5 & 4 & 3 & 4 & 4 & 4 & 4 & 5 & 4 & 65 & & 4225 \\
\hline 11 & R-11 & 5 & 4 & 4 & 4 & 5 & 4 & 4 & 4 & 5 & 5 & 5 & 5 & 5 & 5 & 5 & 4 & 73 & & 5329 \\
\hline 12 & R-12 & 3 & 3 & 3 & 4 & 3 & 3 & 3 & 4 & 2 & 2 & 4 & 4 & 3 & 3 & 3 & 4 & 51 & & 2601 \\
\hline 13 & R-13 & 5 & 5 & 4 & 4 & 4 & 4 & 4 & 5 & 4 & 4 & 5 & 4 & 3 & 4 & 4 & 4 & 67 & & 4489 \\
\hline 14 & R-14 & 5 & 5 & 4 & 4 & 5 & 4 & 4 & 4 & 5 & 5 & 5 & 5 & 4 & 4 & 4 & 4 & 71 & & 5041 \\
\hline 15 & R-15 & 3 & 5 & 2 & 5 & 4 & 5 & 2 & 4 & 5 & 4 & 4 & 5 & 4 & 5 & 4 & 5 & 66 & & 4356 \\
\hline 16 & R-16 & 5 & 4 & 3 & 4 & 5 & 5 & 5 & 5 & 4 & 4 & 4 & 4 & 5 & 5 & 4 & 4 & 70 & & 4900 \\
\hline 17 & R-17 & 5 & 4 & 4 & 5 & 5 & 5 & 5 & 5 & 5 & 5 & 5 & 5 & 5 & 5 & 5 & 5 & 78 & & 6084 \\
\hline 18 & R-18 & 4 & 4 & 4 & 5 & 3 & 4 & 4 & 5 & 4 & 4 & 4 & 4 & 4 & 4 & 4 & 4 & 65 & & 4225 \\
\hline 19 & R-19 & 3 & 3 & 2 & 3 & 2 & 4 & 3 & 4 & 2 & 2 & 4 & 3 & 4 & 3 & 2 & 4 & 48 & & 2304 \\
\hline 20 & R-20 & 4 & 4 & 3 & 5 & 4 & 4 & 4 & 5 & 3 & 4 & 4 & 4 & 4 & 4 & 5 & 5 & 66 & & 435 \\
\hline 21 & R-21 & 4 & 4 & 3 & 5 & 3 & 5 & 2 & 5 & 2 & 2 & 5 & 4 & 5 & 5 & 5 & 4 & 63 & & 396 \\
\hline 22 & R-22 & 3 & 4 & 3 & 4 & 4 & 3 & 2 & 4 & 2 & 3 & 3 & 4 & 4 & 4 & 4 & 4 & 55 & & 3025 \\
\hline 23 & R-23 & 5 & 5 & 4 & 5 & 5 & 5 & 5 & 5 & 5 & 4 & 5 & 5 & 5 & 5 & 5 & 5 & 78 & & 6084 \\
\hline 24 & R-24 & 5 & 5 & 4 & 5 & 5 & 5 & 5 & 5 & 5 & 5 & 5 & 5 & 5 & 5 & 5 & 5 & 79 & & 6241 \\
\hline 25 & $\mathrm{R}-25$ & 4 & 4 & 4 & 4 & 4 & 4 & 3 & 4 & 3 & 3 & 4 & 4 & 3 & 3 & 4 & 4 & 59 & & 348 \\
\hline 26 & R-26 & 5 & 5 & 4 & 4 & 4 & 4 & 3 & 5 & 3 & 3 & 4 & 4 & 4 & 4 & 4 & 4 & 64 & & 409 \\
\hline 27 & R-27 & 4 & 4 & 3 & 5 & 4 & 4 & 4 & 4 & 4 & 4 & 4 & 4 & 4 & 4 & 5 & 4 & 65 & & 422 \\
\hline 28 & R-28 & 5 & 4 & 4 & 5 & 4 & 5 & 4 & 5 & 4 & 4 & 4 & 1 & 5 & 4 & 3 & 5 & 66 & & 435 \\
\hline 29 & R-29 & 4 & 5 & 5 & 5 & 5 & 5 & 1 & 4 & 4 & 4 & 5 & 5 & 4 & 5 & 5 & 5 & 71 & & 5041 \\
\hline 30 & R-30 & 4 & 5 & 3 & 4 & 4 & 5 & 4 & 4 & 4 & 4 & 4 & 5 & 5 & 5 & 4 & 5 & 69 & & 4761 \\
\hline & Sx & 126 & 131 & 103 & 134 & 125 & 129 & 113 & 137 & 113 & 111 & 128 & 127 & 127 & 131 & 129 & 134 & 1998 & & 134632 \\
\hline$\approx$ & $\mathrm{SX}^{2}$ & 544 & 583 & 373 & 608 & 537 & 567 & 457 & 633 & 459 & 431 & 554 & 557 & 553 & 585 & 573 & 606 & $\mathrm{k}$ & $=$ & \\
\hline 害 & SXY & 8508 & 8812 & 6952 & 8987 & 8457 & 8681 & \begin{tabular}{l|}
7647 \\
\end{tabular} & 9171 & 7662 & 7538 & 8593 & 8547 & 8556 & 8839 & 8693 & 8989 & $\mathrm{Ss}^{2}{ }_{b}$ & $=$ & 8.560 \\
\hline 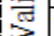 & $r_{x y}$ & 0.765 & 0.667 & 0.530 & 0.514 & 0.830 & 0.646 & 0.547 & 0.436 & 0.596 & 0.816 & 0.615 & 0.510 & 0.631 & 0.803 & 0.600 & 0.598 & $\mathrm{~s}_{\mathrm{t}}^{2}$ & $=$ & 52.173 \\
\hline & \begin{tabular}{|l|l|}
$r_{\text {tabel }}$ \\
\end{tabular} & 0.361 & 0.361 & 0.361 & 0.361 & 0.361 & 0.361 & 0.361 & 0.361 & 0.361 & \begin{tabular}{|l|}
0.361 \\
\end{tabular} & \begin{tabular}{l|}
0.361 \\
\end{tabular} & 0.361 & 0.361 & 0.361 & 0.361 & 0.361 & $r_{11}$ & $=$ & 0.892 \\
\hline & Kriteria & Valid & Valid & Valid & Valid & Valid & Valid & Valid & Valid & Valid & Valid & Valid & Valid & Valid & Valid & Valid & Valid & & & \\
\hline & $\mathrm{s}^{2} \mathrm{~b}$ & \begin{tabular}{|l|l|}
0.493 \\
\end{tabular} & 0.366 & 0.646 & 0.316 & \begin{tabular}{|l|}
0.539 \\
\end{tabular} & 0.410 & 1.046 & 0.246 & 1.112 & 0.677 & 0.262 & 0.646 & 0.512 & 0.432 & 0.610 & 0.249 & & & \\
\hline
\end{tabular}


Lampiran 4

\title{
INSTRUMEN ANGKET
}

\section{KESENANGAN MENDENGARKAN MUSIK DANGDUT \\ KARYAWAN HOME INDUSTRY TRIO}

TAHUN 2016

\begin{abstract}
Nama :
Usia :

Bagian :

PETUNJUK

Pilihlah salah satu jawaban yang anda anggap paling sesuai dengan keadaan anda yang sebenarnya dengan memberikan tanda $(X)$ atau $(\sqrt{ })$ pada tempat yang telah disediakan! Isilah angket ini dengan rasa penuh tanggung jawab dan jujur. Terima kasih dan selamat mengerjakan!
\end{abstract}

1. Anda suka mendengarakan musik dangdut!
a. Sangat suka ( )
b. Suka ( )
c. Cukup suka ( )
d. Kurang suka ( )
e. Tidak suka sama sekali ( )

2. Anda mendengarkan musik secara rutin setiap kali bekerja setiap hari!
a. Sangat rutin ( )
b. Rutin ( )
c. Cukup rutin $(\quad)$
d. Kurang rutin ( ) 
e. Tidak rutin sama sekali ( )

3. Mendengarkan musik lain lebih anda sukai dibanding dengan mendengarkan musik dangdut!
a. Sangat suka ( )
b. Suka ( )
c. Cukup suka ( )
d. Kurang suka ( )
e. Tidak suka sama sekali ( )

4. Mendengarkan musik dangdut berpengaruh terhadap perilaku anda yang bersifat negativ pada saat melakukan pekerjaan!
a. Sangat berpengaruh ( )
b. Berpengaruh ( )
c. Cukup berpengaruh ( )
d. Kurang berpengaruh ( )
e. Tidak berpengaruh sama sekali ( )

5. Mendengarkan musik dangdut saat bekerja merupakan kepuasan hati anda!
a. Sangat setuju ( )
b. Setuju ( )
c. Cukup setuju ( )
d. Kurang setuju ( )
e. Tidak setuju sama sekali ( )

6. Dengan mendengarkan musik dangdut memicu perasaan senang saat bekerja!
a. Sangat setuju ( )
b. Setuju ( )
c. Cukup setuju ( )
d. Kurang setuju ( )
e. Tidak setuju sama sekali ( )

7. Ada niat anda untuk tidak mendengarkan musik dangdut saat bekerja!
a. Sangat setuju ( ) 

b. Setuju ( )
c. Cukup setuju ( )
d. Kurang setuju ( )
e. Tidak setuju sama sekali ( )

8. Anda mendengarkan musik dangdut saat bekerja untuk mendapatkan pujian!
a. Sangat setuju ( )
b. Setuju ( )
c. Cukup setuju ( )
d. Kurang setuju ( )
e. Sangat tidak setuju ( )

9. Anda suka melihat musik dangdut bila ada pertunjukan secara langsung!
a. Sangat suka ( )
b. Suka ( )
c. Cukup suka ( )
d. Kurang suka ( )
e. Tidak suka sama sekali ( )

10. Anda mendengarkan musik dangdut sekaligus mendalami dan memahami isi syair lagu!
a. Sangat setuju ( )
b. Setuju ( )
c. Cukup setuju ( )
d. Kurang setuju ( )
e. Sangat tidak setuju ( )

11. Anda merasa bosan ketika mendengarkan musik dangdut saat bekerja!
a. Sangat setuju ( )
b. Setuju ( )
c. Cukup setuju ( )
d. Kurang setuju ( )
e. Sangat tidak setuju ( ) 
12. Mendengarkan musik dangdut membawa beban pikiran anda menjadi bertambah!
a. Sangat setuju ( )
b. Setuju ( )
c. Cukup setuju ( )
d. Kurang setuju ( )
e. Sangat tidak setuju ( )

13. Mendengarkan musik dangdut sebagai dorongan agar lebih semangat bekerja bagi anda!
a. Sangat setuju ( )
b. Setuju ( )
c. Cukup setuju ( )
d. Kurang setuju ( )
e. Sangat tidak setuju ( )

14. Mendengarkan musik sebagai sarana refresing menghilangkan kebosanan bagi anda!
a. Sangat setuju ( )
b. Setuju ( )
c. Cukup setuju ( )
d. Kurang setuju ( )
e. Sangat tidak setuju ( )

15. Anda mendengarkan musik dangdut karena mengikuti karyawan lain, agar mendapatkan teman!
a. Sangat setuju ( )
b. Setuju ( )
c. Cukup setuju ( )
d. Kurang setuju ( )
e. Sangat tidak setuju ( ) 
16. Mendengarkan musik dangdut akan mempersulit pekerjaan anda!
a. Sangat setuju ( )
b. Setuju ( )
c. Cukup setuju ( )
d. Kurang setuju ( )
e. Sangat tidak setuju ( ) 


\section{INSTRUMEN BORANG}

PENILAIAN TINGKAT PRODUKTIVITAS

KARYAWAN HOME INDUSTRY TRIO

TAHUN 2016

\begin{tabular}{|c|c|c|c|c|c|c|c|}
\hline \multirow[t]{2}{*}{ No. } & \multirow[t]{2}{*}{ Nama } & \multirow[t]{2}{*}{ Bagian } & \multicolumn{4}{|c|}{ Aspek Penilaian } & \multirow{2}{*}{$\begin{array}{l}\text { Rata } \\
\text { rata }\end{array}$} \\
\hline & & & Absensi & Disiplin & Target & Kualitas & \\
\hline 1. & Wiwit & Bubut & & & & & \\
\hline 2. & Udin & Bubut & & & & & \\
\hline 3. & Doni & Bor & & & & & \\
\hline 4. & Andri & Bor & & & & & \\
\hline 5. & Towo & Pengecoran & & & & & \\
\hline 6. & Ikhfar & Pengecoran & & & & & \\
\hline 7. & Aswin & Bubut & & & & & \\
\hline 8. & Basir & Poles & & & & & \\
\hline 9. & Parjo & Poles & & & & & \\
\hline 10 & Agus & Gerinda & & & & & \\
\hline 11. & Tomas & Repair & & & & & \\
\hline 12. & Barok & Pengecatan & & & & & \\
\hline 13. & Opik & Pengecatan & & & & & \\
\hline 14. & Bambang & Pengemasan & & & & & \\
\hline 15. & Rumli & Pengemasan & & & & & \\
\hline 16 & Tio & Welding & & & & & \\
\hline
\end{tabular}




\begin{tabular}{|l|l|l|l|l|l|l|l|}
\hline 17. & Rojikin & Pengecatan & & & & & \\
\hline 18. & Paung & Welding & & & & & \\
\hline 19. & Lukman & Bending & & & & & \\
\hline 20. & Toni & Bending & & & & & \\
\hline 21. & Bayu & Bending & & & & & \\
\hline 22 & Ozan & Welding & & & & & \\
\hline 23. & Aji & Poles & & & & & \\
\hline 24 & Rokhman & Mesin Pon & & & & & \\
\hline 25 & Danar & Mesin Pon & & & & & \\
\hline 26. & Afan & Mesin Pon & & & & & \\
\hline 27. & Idin & Las Asitilin & & & & & \\
\hline 28. & Dika & Las Asitilin & & & & & \\
\hline 29. & Sugeng & Bor & & & & & \\
\hline 30. & Santo & Repair & & & & & \\
\hline
\end{tabular}

Skala:

\begin{tabular}{|l|l|}
\hline $10-25$ & Tidak memuaskan \\
\hline $26-50$ & Kurang \\
\hline $51-75$ & Cukup Memuaskan \\
\hline $76-100$ & Sangat Memuaskan \\
\hline
\end{tabular}

Mengetahui,

Pimpinan Home Industry Trio. 
H. Rasbin Bin Sarkadi

Lampiran 6

HASIL PENGHITUNGAN MENGGUAKAN SPPS 16 FOR WINDOWS

Uji Normalitas Data 


\section{One-Sample Kolmogorov-Smirnov Test}

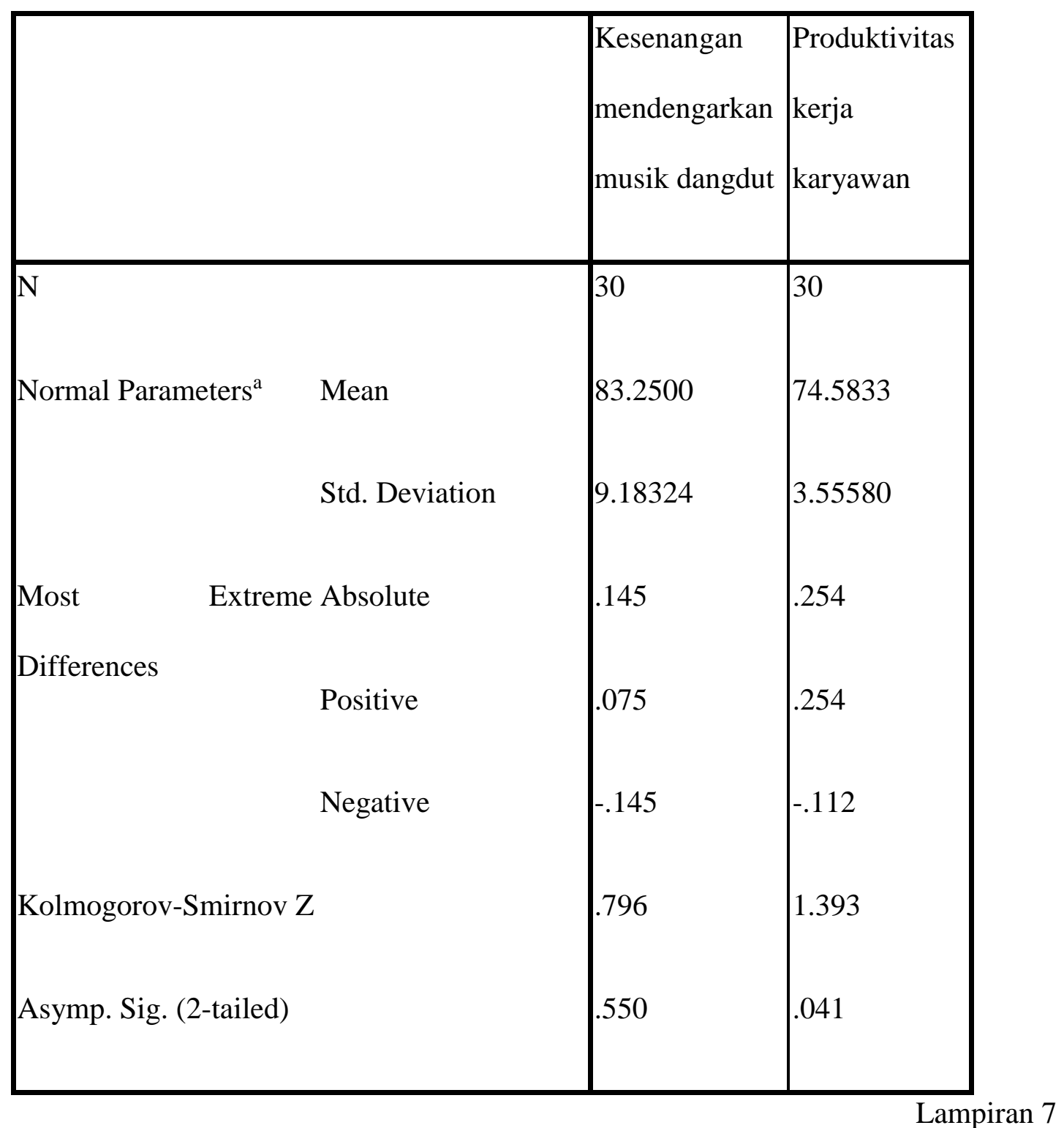

\section{Uji Linieritas}




\section{ANOVA Table}

\begin{tabular}{|c|c|c|c|c|c|c|c|}
\hline & & & $\begin{array}{l}\text { Sum o } \\
\text { Squares }\end{array}$ & f & $\begin{array}{l}\text { Mean } \\
\text { Square }\end{array}$ & $\mathrm{F}$ & Sig. \\
\hline $\begin{array}{l}\text { Produktivitas } \\
\text { kerja karyawan } \\
\text { Kesenangan } \\
\text { mendengarkan } \\
\text { musik dangdut }\end{array}$ & $\begin{array}{l}\text { Between } \\
\text { Groups } \\
\text { Within Gr } \\
\text { Total }\end{array}$ & $\begin{array}{l}\text { (Combined) } \\
\text { Linearity } \\
\text { Deviation from } \\
\text { Linearity } \\
\text { ups }\end{array}$ & $\begin{array}{l}266.146 \\
160.524 \\
105.622 \\
100.521 \\
366.667\end{array}$ & 14 & $\begin{array}{l}17.743 \\
160.524 \\
7.544 \\
7.180\end{array}$ & $\begin{array}{l}2.471 \\
22.35 \\
7 \\
1.051\end{array}$ & $\begin{array}{l}.049 \\
.000 \\
.464\end{array}$ \\
\hline
\end{tabular}

Lampiran 8 


\section{Descriptive Statistics}

\begin{tabular}{|l|l|l|l|}
\hline & Mean & Std. Deviation & N \\
\hline $\begin{array}{l}\text { Produktivitas Karyawan } \\
\begin{array}{l}\text { Kesenangan mendengarkan musik } \\
\text { dangdut }\end{array}\end{array}$ & 74.5833 & 3.55580 & 30 \\
\hline
\end{tabular}

\section{Correlations}

\begin{tabular}{|ll|l|l|}
\hline & & & \\
& & $\begin{array}{l}\text { Produktivitas } \\
\text { Karyawan } \\
\text { mendenganan } \\
\text { musik dangdut }\end{array}$ \\
\hline Pearson Correlation & Produktivitas Karyawan & 1.000 & .662 \\
\hline $\begin{array}{l}\text { Kesenangan mendengarkan } \\
\text { musik dangdut }\end{array}$ & $\begin{array}{l}\text { Produktivitas Karyawan } \\
\text { Kesenangan mendengarkan } \\
\text { musik dangdut }\end{array}$ & .000 & 1.000 \\
\hline Produktivitas Karyawan & 30 & 30 \\
\hline $\begin{array}{l}\text { Kesenangan mendengarkan } \\
\text { musik dangdut }\end{array}$ & 30 & 30 \\
\hline
\end{tabular}

Lampiran 9

\section{UJI DETERMINASI}


Model Summary

\begin{tabular}{|l|l|l|l|l|l|l|l|l|l|}
\hline $\begin{array}{l}\text { Mod } \\
\text { el }\end{array}$ & $\mathrm{R}$ & $\begin{array}{l}\mathrm{R} \\
\text { Square }\end{array}$ & $\begin{array}{l}\text { Adjusted } \\
\text { R Square }\end{array}$ & $\begin{array}{l}\text { Std. Error } \\
\text { of the } \\
\text { Estimate }\end{array}$ & $\begin{array}{l}\text { R Square } \\
\text { Change }\end{array}$ & $\begin{array}{l}\text { F } \\
\text { Change }\end{array}$ & df1 & df2 & $\begin{array}{l}\text { Sig. } \\
\text { Change }\end{array}$ \\
\hline 1 & $.662^{\mathrm{a}}$ & .438 & .418 & 2.71335 & .438 & 21.804 & 1 & 28 & .000 \\
\hline
\end{tabular}

a. Predictors: (Constant), Kesenangan mendengarkan

musik dangdut

b. Dependent Variable: Produktivitas

Karyawan

ANOVA ${ }^{b}$

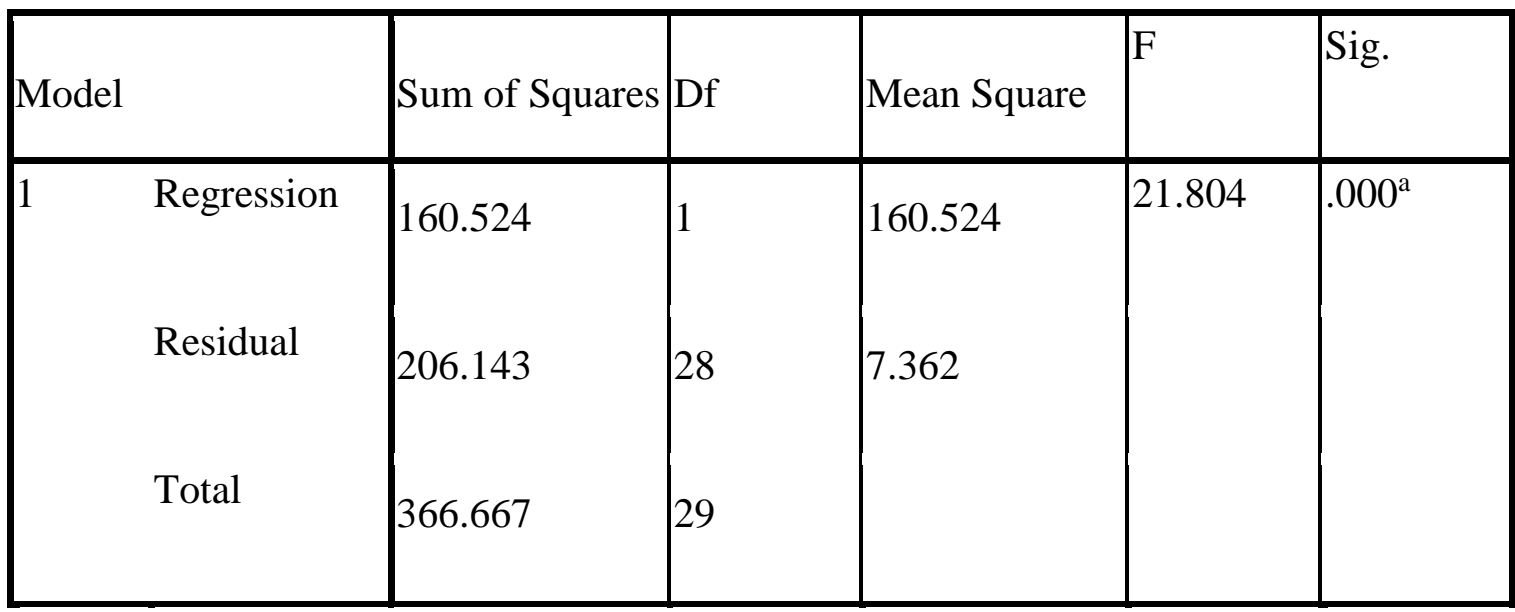

a. Predictors: (Constant), Kesenangan mendengarkan musik dangdut

b. Dependent Variable: Produktivitas Karyawan

Lampiran 10

PERSAMAAN REGRESI 


\section{Coefficients $^{\mathrm{a}}$}

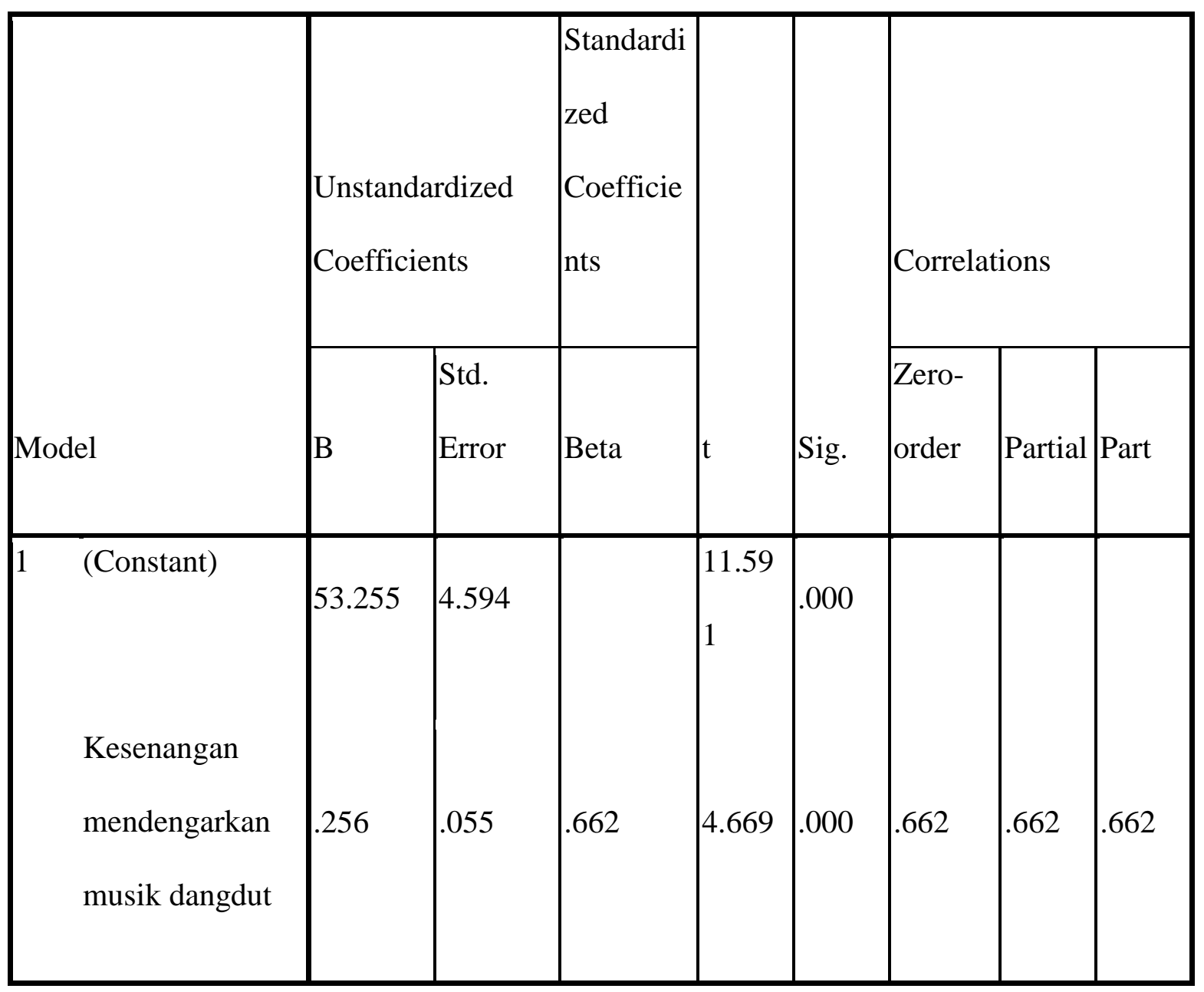

a. Dependent Variable: Produktivitas

Karyawan 
Lampiran 11

\section{DOKUMENTASI}

\section{PROSES PRODUKSI SAMBIL MENDENGARKAN MUSIK DANGDUT}

Gambar 1

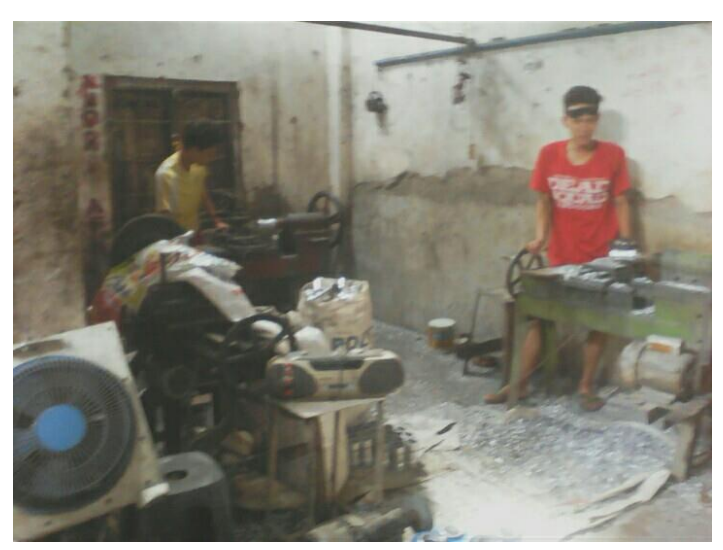

Gambar 3

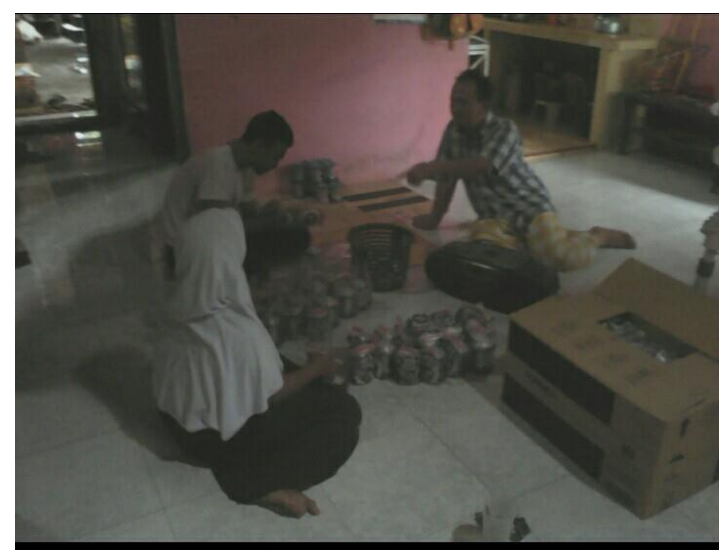

Gambar 2

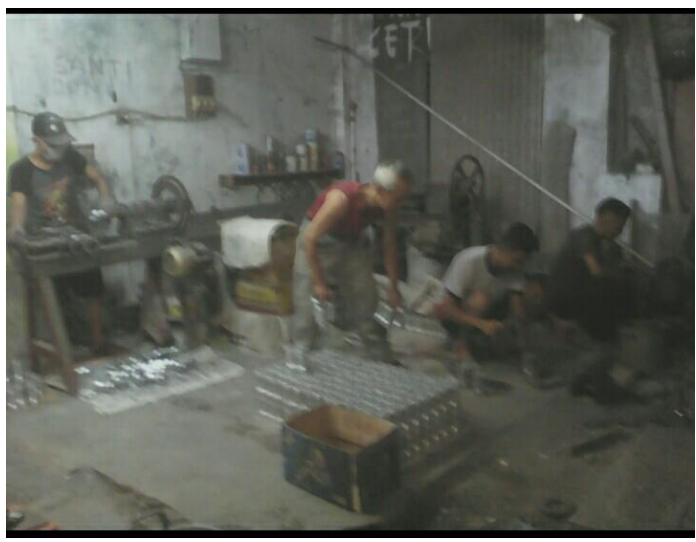

Gambar 4

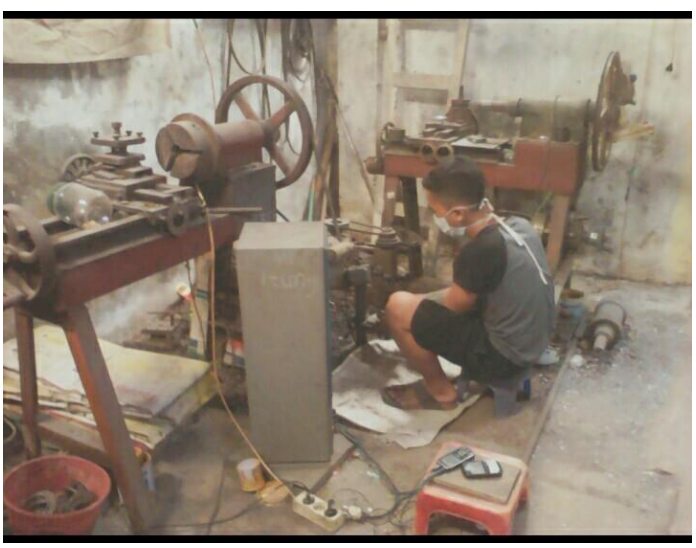


